\title{
Animals in Funerary Rituals at the El-Zuma Cemetery
}

\author{
Urszula Iwaszczuk
}

Introduction

Animal remains have been coming to light in the tombs at El-Zuma since regular excavations were first conducted at this site in 2005. The bone remains from the first two seasons (2005 and 2007) were analysed and published by Marta Osypińska (2005; 2010) and they are not included in this volume. Some comments concerning the results of this earlier work are, however, made in this chapter. The rest of the animal bones, discovered between 2009 and 2012, and partially in the 2007 season, remained in storage awaiting analysis till 2013. The bone fragments from 20132018 were identified during the excavation seasons immediately after their discovery. Some of the material analysed during this study has already been published (Iwaszczuk 2015; Iwaszczuk, Niderla-Bielińska, and Ścieżyńska 2019, 7-21), but some supplementary remarks are made further on herein.

The state of preservation of the tumulus structures is described earlier in this volume (see Chapters 3 and 5). It is, however, important to mention that the graves were looted sometime after the funerary rituals had taken place, which is reflected in the plans and profiles of the various grave structures. In the case of most of the type II and III tumuli the burial chamber (chamber 1) was looted but the additional chambers were left untouched with the material remaining in situ. There were, of course, some exceptions to that pattern (e.g. the ceiling of chamber 2 in T.11 and T.12 was damaged during the looting). Chamber 3 in T.9 and chamber 4 in T.26 could also have been looted, as the ceilings of those graves had collapsed, but the damage to the ceiling could also be attributable to natural processes, such as the humidity of the rock weakening the structure of the ceiling. In other cases the collapse of the ceilings was probably caused by natural factors.

\section{$2 \quad$ Material and Methods}

The number of excavated fragments was high: 15,191 bone and tooth fragments from 20 tumuli (nos. 1, 3, 4, 6, 7, 8, 9, 11, $12,13,14,15,16,17,19,20,21,24,26$, and 28 ) and two almostcomplete skeletons of small rodents (with skin) excavated from T.6 were analysed. Additionally, in T.13 five fragments of one bivalve shell were found. A few animal bones were discovered in chamber 2 of T.23, according to the field documentation; however, they were subsequently lost when the finds were moved to a new storage location. A similar situation concerned animal remains from an original deposit found in T.22. Only 31 fragments belonging to 13 bones from the re-exploration of this part of the tomb were submitted for analysis. These remains have not been included in this analysis, as they might have come from the recent sand layers accumulated in the vicinity of the tumuli.

Animal bones were identified to a zoological taxon and anatomical element. Ovicaprine remains were identified according to standard methods (Schramm 1967; Zeder and Lapham 2010; Zeder and Pilaar 2010). Estimation of the age of individuals was carried out based on the fusion of long bone epiphyses with shafts, the fusion of pelvic bones and the degree of development of the glenoid articulation of the scapula (Kolda 1936). Tooth development was also taken into consideration (Lutnicki 1972); however, teeth were very seldom found among the animal remains in the excavated graves. The morphotypes of sheep and cattle were analysed on the basis of measurements according to Driesch's (1976) method and coefficients estimated for sheep by Teichert (von den Driesch and Boessneck 1974) and for cattle by Matolcsi (von den Driesch and Boessneck 1974) and Fock (1966). The minimum number of individuals (MNI) was calculated for all species recovered from the tumuli using the most frequent bone elements in the assemblages, also taking into consideration the size of the bones and, in some cases, the age and sex of the individuals. In the case of animals other than cattle and sheep (e.g. donkey, camel, horse, and goat) measurements were taken but, as such remains were very scarce, further analysis on the morphotypes of these animals was impossible. Nevertheless, all of the measurements are listed in Table 8.1. 
TABLE 8.1 Measurements of mammal bones from El-Zuma Tumulus 1

\begin{tabular}{|c|c|c|c|c|}
\hline \multicolumn{5}{|c|}{ CATTLE } \\
\hline \multicolumn{3}{|c|}{ Scapula } & \multicolumn{2}{|r|}{ Radius } \\
\hline \multirow{2}{*}{\multicolumn{3}{|c|}{ SLC }} & \multicolumn{2}{|r|}{$\mathrm{Bp}$} \\
\hline & & & \multicolumn{2}{|r|}{71} \\
\hline \multicolumn{3}{|c|}{45} & \multicolumn{2}{|r|}{77.2} \\
\hline \multicolumn{3}{|c|}{41.5} & \multicolumn{2}{|r|}{84.2} \\
\hline \multicolumn{4}{|c|}{ Metacarpal } & Tibia \\
\hline $\mathrm{Bp}$ & $\mathrm{Bd}$ & SD & $\mathrm{DD}$ & $\mathrm{Bd}$ \\
\hline \multirow[t]{2}{*}{64.8} & & 36.3 & 26.4 & 57 \\
\hline & 59.8 & & & \\
\hline \multicolumn{5}{|c|}{ DONKEY } \\
\hline
\end{tabular}

\section{Humerus}

\begin{tabular}{c}
\hline Bd \\
\hline 58
\end{tabular}

\section{Metacarpal}

\begin{tabular}{c|c|c|c|c|c}
\hline GL & GLl & Bp & Bd & SD & DD \\
\hline 181.5 & 176.8 & 37.8 & 34.1 & 23.7 & 20.1 \\
\hline \multicolumn{2}{c|}{ HORSE } & \multicolumn{3}{|c}{ CAMEL } \\
\hline Pelvis & \multicolumn{2}{|c}{ Talus } \\
\hline LA & \multicolumn{2}{|c}{ GLm } \\
\hline 69.4 & 74 \\
\hline
\end{tabular}

Tumulus 3

\begin{tabular}{c|c|c}
\hline \multicolumn{3}{c}{ CATTLE } \\
\hline \multicolumn{3}{c}{ Scapula } \\
\hline GLP & BG & SLC \\
\hline 58.4 & 51 & 57 \\
\hline
\end{tabular}

\section{Humerus}

\begin{tabular}{c|c|c}
\hline \multicolumn{3}{c}{ Bd } \\
\hline \multicolumn{3}{c}{70.5} \\
\hline \multicolumn{3}{c}{ Radius } \\
\hline Bp & Bd & SD \\
\hline 84.5 & 77.7 & 44.8 \\
\hline
\end{tabular}

\section{Tibia}

\begin{tabular}{c|c|c}
\hline Bp & Bd & SD \\
\hline 95 & 54.6 & \\
\hline 9 & 58.2 & 41.3 \\
\hline \multicolumn{3}{|c}{ SHEEP } \\
\hline
\end{tabular}

\begin{tabular}{c|c}
\hline Humerus & Pelvis \\
\hline Bd & LA \\
\hline 32.5 & 22.8 \\
\hline
\end{tabular}


TABLE 8.1 Measurements of mammal bones from El-Zuma (cont.) Tumulus 4

\begin{tabular}{|c|c|c|c|c|}
\hline \multicolumn{5}{|c|}{ CATTLE } \\
\hline Scapula & Humerus & Radius & $\begin{array}{l}\text { Meta- } \\
\text { carpal }\end{array}$ & Pelvis \\
\hline \multirow{2}{*}{ SLC } & $\mathrm{Bd}$ & $\mathrm{Bd}$ & $\mathrm{Bd}$ & LA \\
\hline & 82 & \multirow{3}{*}{65.7} & 48.3 & \multirow{3}{*}{56.3} \\
\hline 56.8 & 80.2 & & $59 \cdot 4$ & \\
\hline 47.2 & 63 & & 47 & \\
\hline \multicolumn{2}{|c|}{ Femur } & \multicolumn{3}{|c|}{ Tibia } \\
\hline Bp & $\mathrm{Bd}$ & GL & & \\
\hline \multirow[t]{3}{*}{120.3} & & & \multicolumn{2}{|c|}{$55 \cdot 9$} \\
\hline & \multirow{2}{*}{$|85|$} & 349 & \multicolumn{2}{|c|}{$59 \cdot 3$} \\
\hline & & & \multicolumn{2}{|c|}{$57 \cdot 3$} \\
\hline
\end{tabular}

Talus

\begin{tabular}{c|c|c}
\hline GLl & GLm & Bd \\
\hline 64.9 & 61.9 & 41.4 \\
\hline 68.7 & 60 & 43 \\
\hline 64 & 59.5 & 41.5 \\
\hline 64.5 & 59.6 & 40.8 \\
\hline 67.4 & 62.9 & 44.8 \\
\hline
\end{tabular}

Metatarsal

\begin{tabular}{c|c|c|c|c}
\hline GL & Bp & Bd & SD & DD \\
\hline & 46.3 & 54 & 25.4 & 27.8 \\
\hline 233 & 40.4 & $45 \cdot 3$ & 23 & 23.8 \\
\hline
\end{tabular}

Tumulus 4 (cont.)

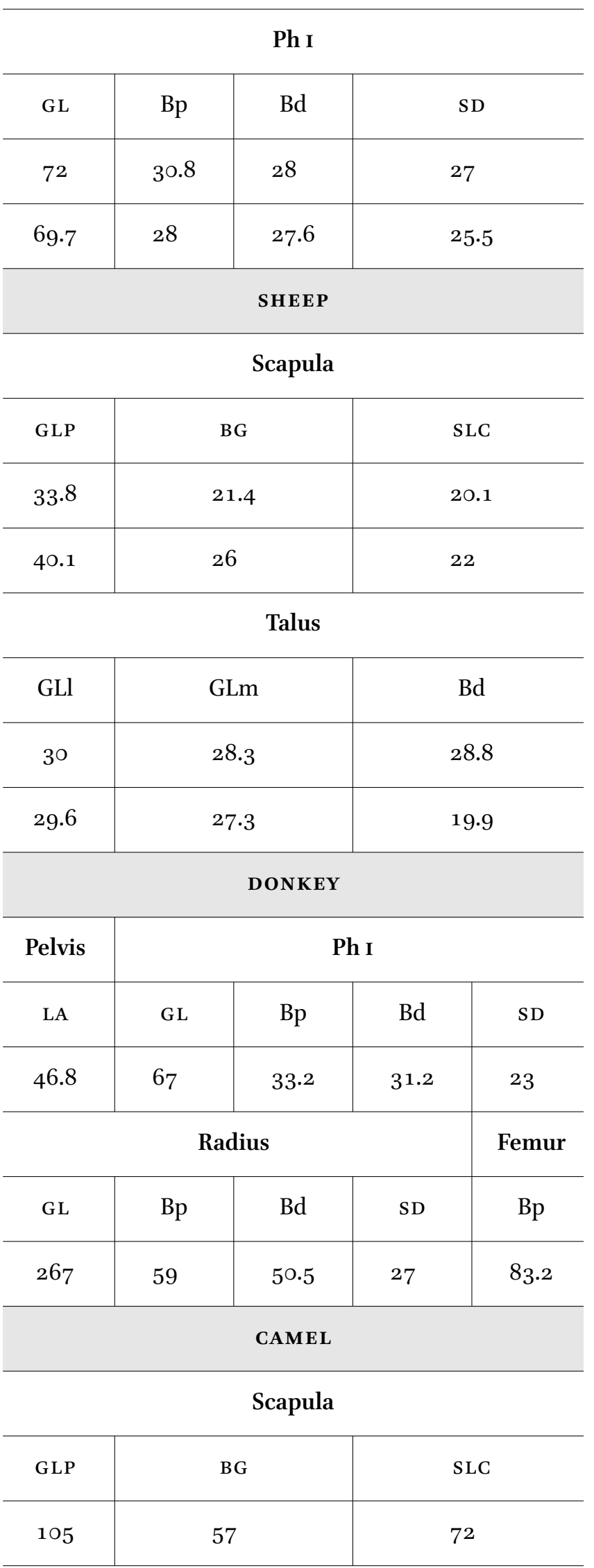


TABLE 8.1 Measurements of mammal bones from El-Zuma (cont.) Tumulus 4 (cont.)

\begin{tabular}{c|c}
\hline Humerus & Metacarpal \\
\hline Bd & Bp \\
\hline 87.8 & 59 \\
\hline
\end{tabular}

Tumulus 6

\begin{tabular}{c|c|c}
\hline \multicolumn{3}{c}{ DON KEY } \\
\hline \multicolumn{3}{c}{ Ph II } \\
\hline GL & GB & Ld \\
\hline 40.2 & 45 & 39.3 \\
\hline
\end{tabular}

Tumulus 7

\begin{tabular}{c|c|c|c}
\hline \multicolumn{3}{c}{ CATTLE } \\
\hline Metacarpal & \multicolumn{3}{c}{ Talus } \\
\hline Bp & GLl & GLm & Bd \\
\hline 47.2 & 69.8 & 63.1 & 45.2 \\
\cline { 2 - 4 } & 57.2 & 54.5 & \\
\hline
\end{tabular}

PRODUCED BY U. IWASZCZUK

\section{State of Preservation}

High temperatures during summer, long periods of drought, and sudden and violent floods were the main factors responsible for the poor state of preservation of the bones. These specific conditions of the Sudanese desert made the bones very dry and fragile, almost devoid of organic components. Some of the bones were also weathered, which is a natural consequence of exposure to water followed by high temperatures [Fig. 8.1]. During the excavations, after contact with fresh air, some of the bones crumbled into small pieces, sometimes leaving only bone powder. The long period of storage (from 2007 till 2013) was also detrimental to the bones [Fig. 8.2]. All these factors had an impact on the significant difference between the number of identified bone frag- ments (NISP) and the minimum number of bone elements $(\mathrm{MNE})$ : in some cases fragments that came from one bone were extremely numerous (over 100 fragments per bone). Analysis of the assemblages was, therefore, rather timeconsuming, and measurement of the excavated bones was very rarely possible. That is why only 79 cattle and 34 sheep bone elements, such as scapula, pelvis, long bones, and talus were measured. In the case of other animals (donkey, camel, goat, and horse) measurements were taken from 14 bones and fragments of bones. It should also be mentioned that only a few bones were preserved as whole bone elements that enabled all measurements to be taken according to Driesch's (1976) method, and thus made it possible to calculate the withers height of the animals. The author is aware that the coefficients used in this research were originally formulated for European populations of domestic animals and, therefore, the results may be treated only as a suggestion.

It is worth noting that some of the bones bore postconsumption marks as well as marks made by animals. Marks left by animals had a particularly significant impact on the degree of bone fragmentation after carcass parts and meat had been deposited in the graves. Two types of such marks were recorded on the bones from El-Zuma.

The first type, gnawing by rodents, has also been attested at many other sites and is easy to identify. Bones with this type of modification were, however, relatively few. All of these marks were made by rodents of mouse rather than rat size [Fig. 8.3]. Bones of small rodents were present in the tunnels of the biggest tumuli (type I), as were bones bearing marks made by these animals. Only one bone with gnawing marks was found in a type II tumulus (T.26). Such marks were visible on the bones of different animals: cattle, sheep/goat, horse, donkey, camel, and gazelle. They were also recorded on bones from different parts of carcasses. All this suggests that there were no preferences in choosing bones for gnawing. It is possible then that they were used by rodents as a rasp to wear down the incisors that grow throughout the lifetime of these animals, especially given that such marks were also discovered on some pieces of pottery (see Volume II, Chapter 6, p. 16o).

The other type of marks of animal origin recorded on the bones from El-Zuma were much more interesting [Fig. 8.4]. Bones with these marks were found in only some of the type I and II tumuli and in one tumulus of type III. Thirteen of the total number of 20 graves analysed between 2013 and 2018 were found to contain bones bearing such marks (T.1, T.4, T.7 and T.8 of type I, T.11, T.12, T.13, T.14, T.15, T.16, T.24, and T.26 of type II, and T.17 of type III). The marks themselves were unusual and had 


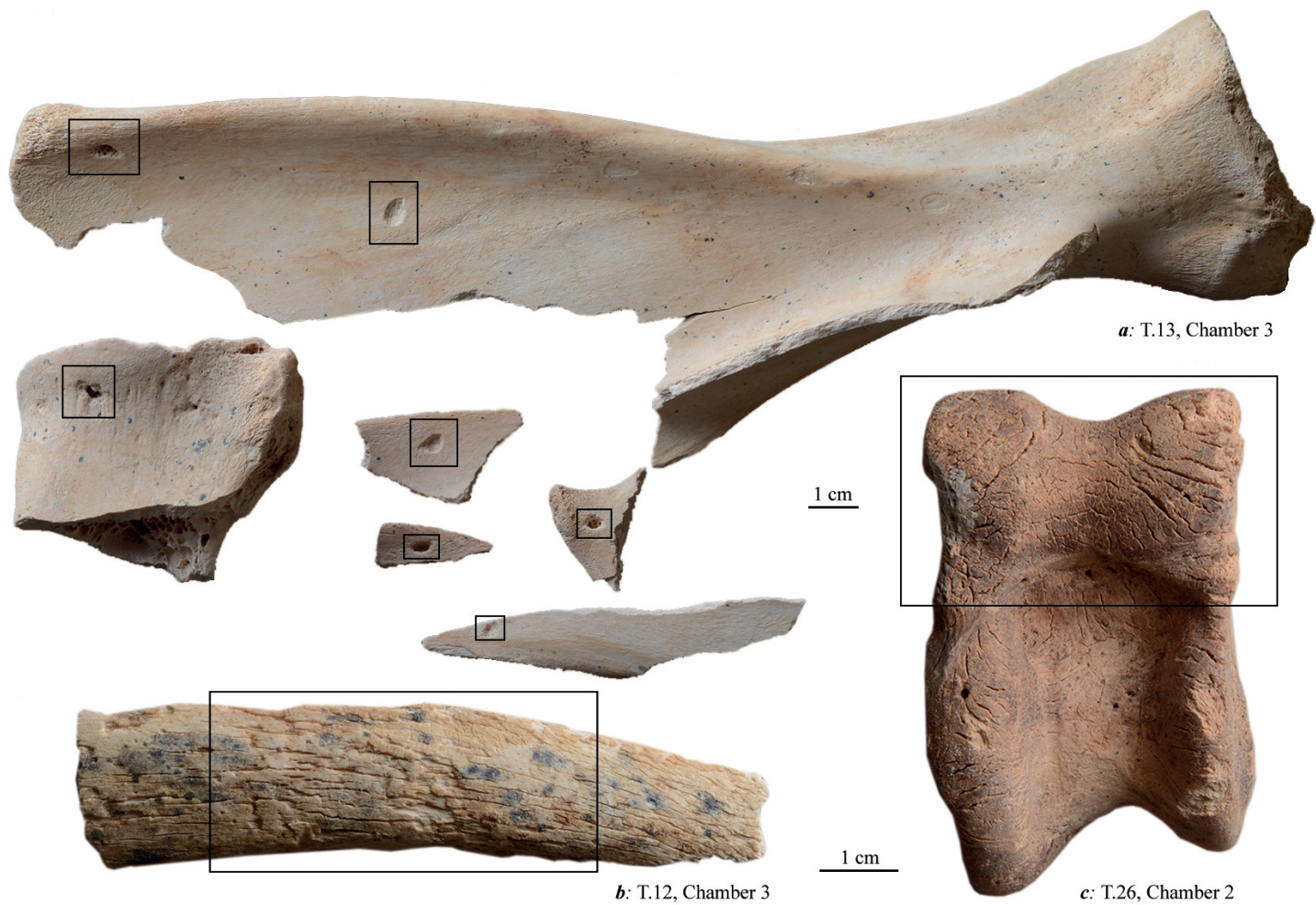

FIGURE 8.1 State of preservation of animal remains from El-Zuma: a-bone fragmentation, left and right sheep scapulas (right scapula in several pieces bears marks probably left by larvae); $b$ and $c-$ weathered bones

PHOTOS BY A. KAMROWSKI

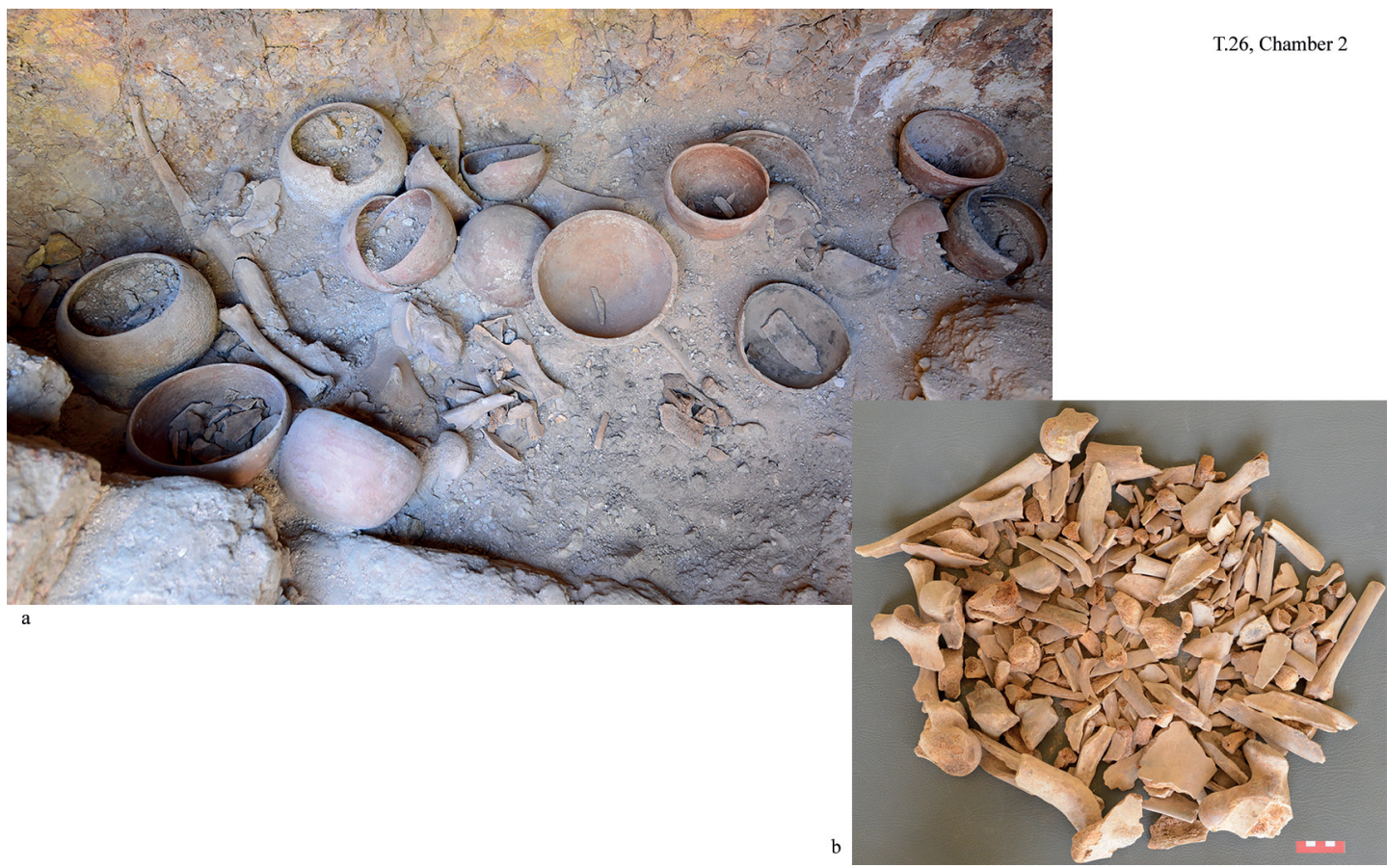

FIGURE 8.2 State of preservation of the animal remains from the southern part of chamber 2 in T.26 at El-Zuma: $\mathrm{a}$-in situ; $\mathrm{b}$ - during analysis

PHOTOS BY A. KAMROWSKI 

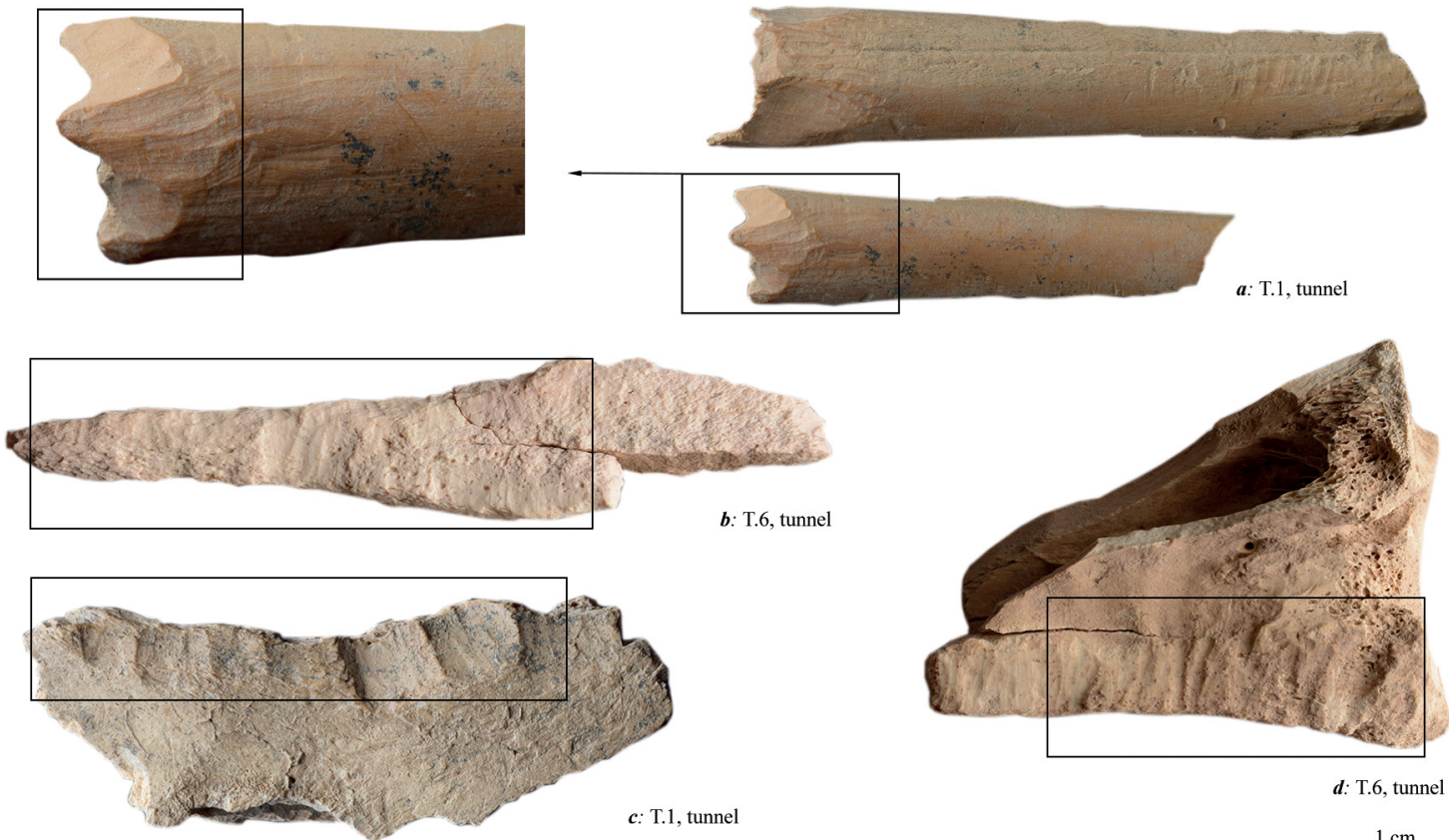

FIGURE 8.3 Rodent gnawing marks on mammal bones found in the tunnels of type I tumuli at El-Zuma

РнотOS BY A. KAMROWSKI
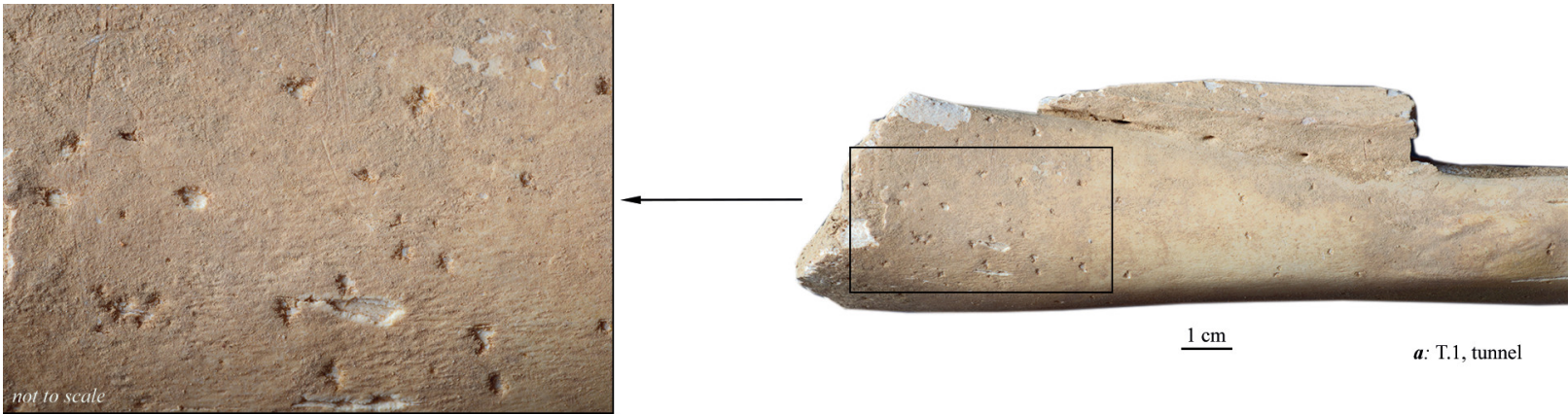

$\underline{1 \mathrm{~cm}}$

$1 \mathrm{~cm}$
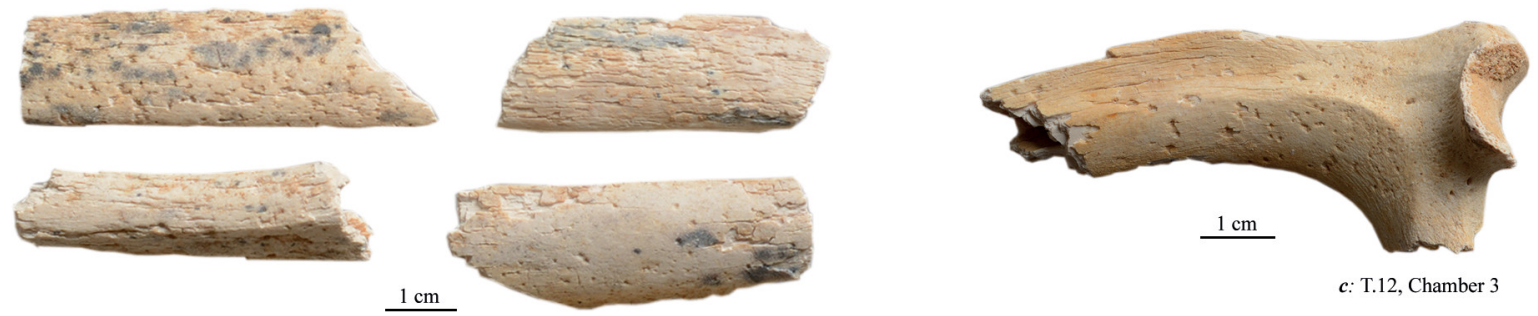

$\boldsymbol{b}$ : T.12, Chamber 3

c: T.12, Chamber 3

FIGURE 8.4 Termite gnawing marks visible on bones from tumuli of types I and II at El-Zuma PHOTOS BY A. KAMROWSKI 

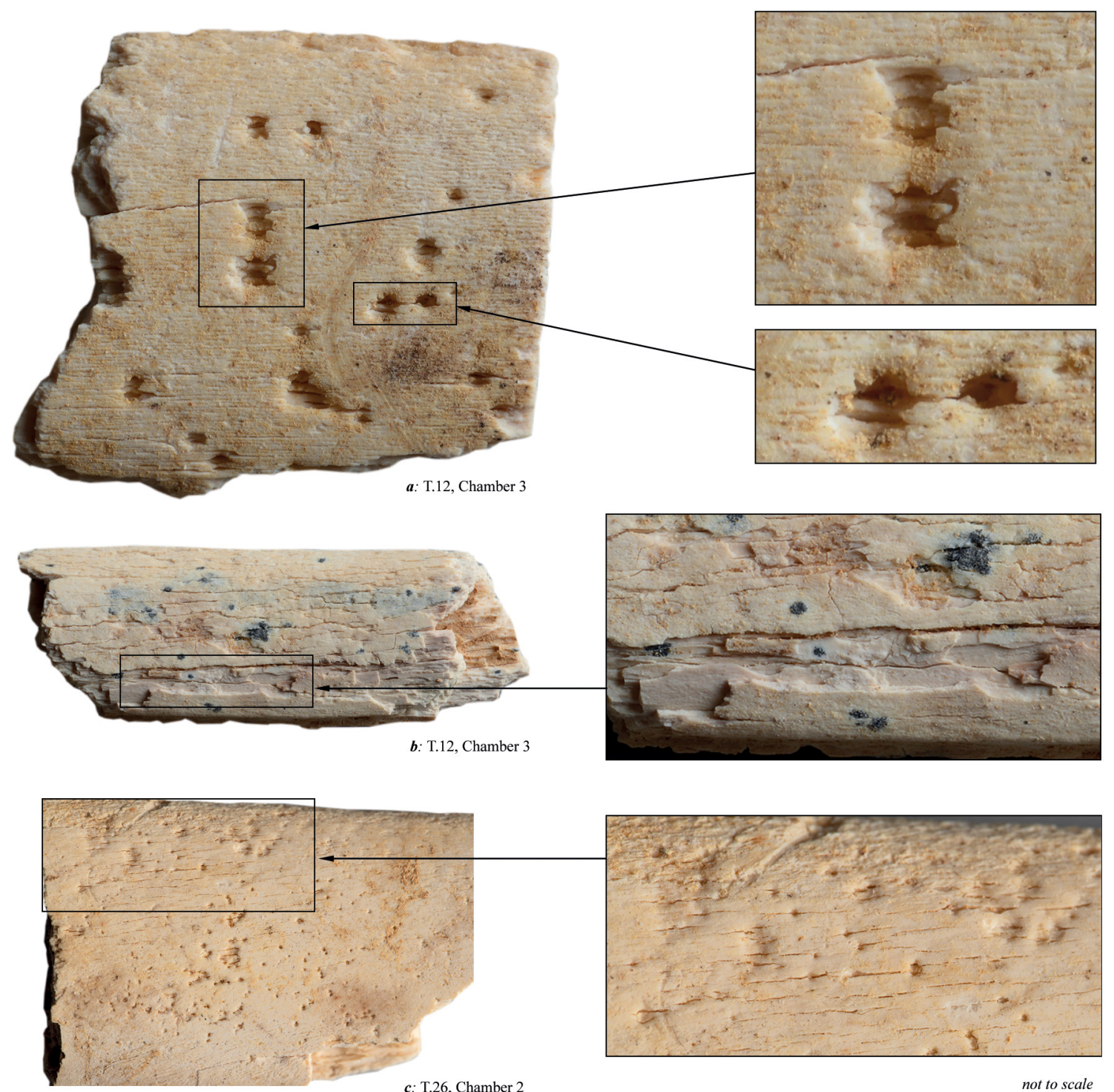

FIGURE 8.5 Different types of gnawing marks left by termites on bones from tumuli of types I and II at El-Zuma

PHOTOS BY A. KAMROWSKI

never previously been recorded in this area. In some cases they were separated from each other, while some of them merged into larger patches. The bones, however, were also modified in another way (i.e. they were weathered), which made this pattern not so evident and clear and therefore more difficult to detect. The marks in question were similar at first glance to marks made by certain larvae (Lyman 1994, 394; Huchet et al. 2013), but without the characteristic grooves left by them. They also differed in other details: for instance, they looked as if they were made by gnawing the bone surface starting from the central points and creating a star-shaped pattern [Fig. 8.5]. The small holes visible on the surface of the bones were also unlike the holes left by wasps or wild bees (Pittoni 2009). The closest analogy to these marks seems to be the alteration of bone surfaces recorded by Backwell et al. (2012, see also references therein) as marks left by the subterranean termite Trinervitermes trinervoides. The example shown by Huchet $(2014,340$, Fig. 7 e) seems to confirm the suggestion connecting these marks with termites. At least four types of patterns correspond to the features described by these authors [see Fig. 8.5]: an etched appearance, surface residue, star-shaped marks and surface pits. Star-shaped marks, which were also observed in the El-Zuma material, are especially characteristic of these insects. 


\section{$4 \quad$ Results}

\subsection{Type I Tumuli}

Type I tumuli were the largest and most complicated structures from an archaeological as well as an archaeozoological point of view, and yielded the richest faunal assemblages from the greatest variety of contexts. The animal bones were located in chambers, grave shafts, tunnels, shafts leading to the tunnels and in robber pits. The remains from two tumuli of this type (T.2 and T.5) were analysed by Osypińska (2005; 2010), and they are not included in this analysis. The contexts in which the animal bones were discovered have already been described in detail in the case of three type I graves: T.3, T.4 and T.7 (Iwaszczuk, Niderla-Bielińska, and Ścieżyńska 2019, 7-21), and so will only be mentioned in passing herein. The animal bones from other graves (T.1, T.6 and T.8) are presented in detail.

\subsubsection{Tumulus 1}

There were 68 o animal bone fragments found in this grave. More than one-third of that number remain unidentified (273 fragments). Most of the remains were discovered in the tunnel, scattered along its entire length. Only 33 fragments from 1 cattle mandible and 17 fragments from 3 cattle teeth that belonged to a very young individual aged about $5^{-6}$ months, were found in the robber pit [Table 8.2].

The bone fragments from the tunnel belonged to 3 cattle individuals: one was about $2-2.5$ years old, another was about $3 \cdot 5^{-5}$ years old, and the third one was much older-it was more than 5 years old at death. Bones represented only some parts of the carcass: the head, thorax, forelimb, and hind limb without extremities. The bones bore no post-consumption marks but some of them were gnawed by rodents (fragments of mandible and radius) and carnivores (humerus and radius). One of the tooth roots also showed traces of a mild inflammatory process.

Sheep bones were much less numerous: there were only 23 fragments representing 6 bones. All but one belonged to a female aged over 21-24 months. A fragment of mandible belonged to a younger, but not very young, animal of more than 9 months. Only one of the bones bore marks indicative of gnawing by rodents.

Goat was represented solely by 2 horncores from the left and right side of the same skull of an adult female individual. The left one had been chopped about $1 \mathrm{~cm}$ above its base. Other ovicaprine remains representing only 4 bones probably belonged to the older sheep mentioned above. They came from the part of the limbs with good-quality meat. The radius featured carnivore gnawing marks. There were also 7 fragments of 2 teeth that were found at the top of the fill in the western part of the tunnel.

The discovery of bones of transportation animals, such as donkey, horse, and camel, was a great surprise in the light of previous finds that had delivered only cattle and sheep remains. They were few and represented different parts of the carcass. In the case of camel there were only 19 fragments of 5 bones from the head and hind limb of 1 adult female. The calcaneus had been gnawed by rodents. Additionally, one talus was found in the robber pit. This bone could also have come from the individual mentioned above; however, it could be a skeletal element that had got into this assemblage accidentally. The bones of donkey were also few: only 15 fragments from 7 bones of 1 adult animal were found in the tunnel. The bones came from the head and proximal part of a forelimb. The humerus had been gnawed by carnivores. Only 1 fragment of horse pelvis was recorded in the material; it came from 1 adult individual and bore marks of gnawing by rodents.

There was also a group of 20 fragments from 7 equid bones (cranial elements, a fragment of pelvis, and metapodial bones) that could not be identified to species. A small but thickset metacarpal among these bones could probably belong to a mule or a very small horse. This bone was burnt at the distal end. Additionally, a fragment of pelvis had been gnawed by carnivores. The bones from this group probably came from 2 adult animals, but it is not certain if they belonged to the individuals of horse and donkey described above or to another two animals.

Nine fragments of 4 bones of a game animal were noted in the material. All of them belonged to gazelle. This genus was represented by a fragment of mandible, shafts of both tibias, and a metatarsal of an adult animal. The mandible had been gnawed by rodents.

The last group of bones consisted of 3 long bones of a bird.

\subsubsection{Tumulus 3}

The bone material from this grave has already been described (Iwaszczuk, Niderla-Bielińska, and Ścieżyńska 2019, 7-21). Animal remains were found in the tunnel and in two partially explored chambers (nos. 1 and 2), though it is possible that some of the material from these chambers had been discarded in the tunnel during looting together with other artefacts of no greater value to the robbers. From the total number of 381 bone fragments, 45 remain unidentified. The zoological and anatomical distribution of the animal remains given in Table 8.3 shows the variety of species found in this grave: bones of animals traditionally used as offerings were found in different contexts, as were porcupine [Fig. 8.6], dog, micro-mammal, 
TABLE 8.2 Animal remains discovered in T.1

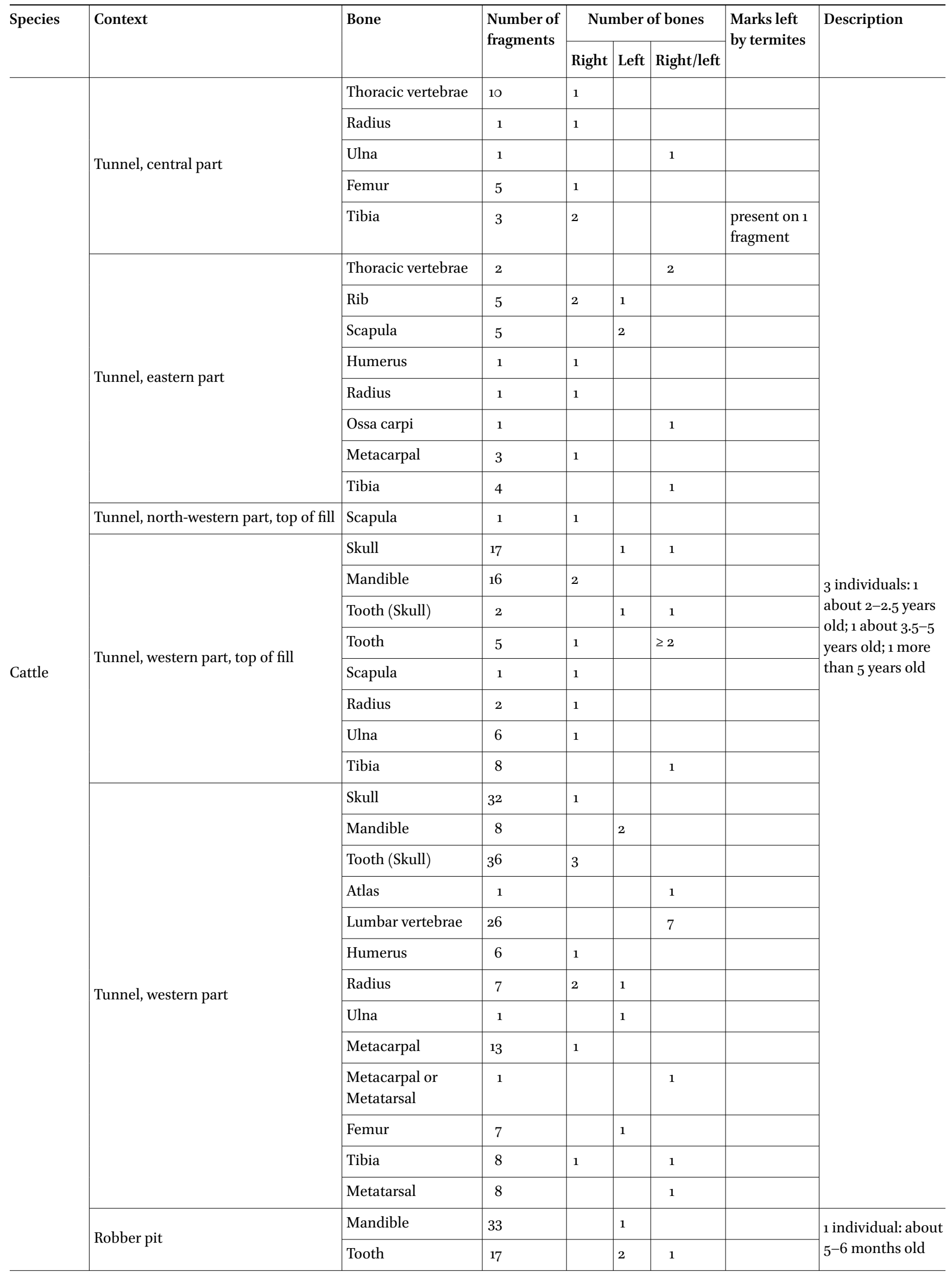


TABLE 8.2 Animal remains discovered in T.1 (cont.)

\begin{tabular}{|c|c|c|c|c|c|c|c|c|}
\hline \multirow[t]{2}{*}{ Species } & \multirow[t]{2}{*}{ Context } & \multirow[t]{2}{*}{ Bone } & \multirow{2}{*}{$\begin{array}{l}\text { Number of } \\
\text { fragments }\end{array}$} & \multicolumn{3}{|c|}{ Number of bones } & \multirow{2}{*}{$\begin{array}{l}\text { Marks left } \\
\text { by termites }\end{array}$} & \multirow[t]{2}{*}{ Description } \\
\hline & & & & Right & Left & Right/left & & \\
\hline \multirow{6}{*}{ Sheep } & Tunnel, eastern part & Mandible & 2 & 1 & & & & \multirow{6}{*}{$\begin{array}{l}2 \text { individuals: } \\
1 \text { more than } 9 \\
\text { months (only part } \\
\text { of mandible); } 1 \\
\text { female, more than } \\
21-24 \text { months }\end{array}$} \\
\hline & \multirow{3}{*}{ Tunnel, western part } & Skull & 1 & 1 & & & & \\
\hline & & Horn core & 1 & 1 & & & & \\
\hline & & Metatarsal & 1 & & & 1 & & \\
\hline & \multirow{2}{*}{ Tunnel, western part, top of fill } & Mandible & 4 & 1 & & & & \\
\hline & & Skull & 14 & & & 1 & & \\
\hline \multirow{2}{*}{ Goat } & Tunnel, eastern part & Horn core & 1 & & 1 & & & \multirow{2}{*}{$\begin{array}{l}1 \text { individual: } \\
\text { female, adult }\end{array}$} \\
\hline & Tunnel, western part & Horn core & 1 & 1 & & & & \\
\hline \multirow{4}{*}{ Ovicaprine } & \multirow{2}{*}{ Tunnel, eastern part } & Pelvis & 2 & 1 & 1 & & & \multirow{4}{*}{$\begin{array}{l}\text { probably from the } \\
\text { older sheep above }\end{array}$} \\
\hline & & Tibia & 1 & & & 1 & & \\
\hline & Tunnel, western part & Radius & 1 & 1 & & & & \\
\hline & Tunnel, western part, top of fill & Tooth & 7 & & & $\geq 2$ & & \\
\hline Horse & Tunnel, western part & Pelvis & 1 & & 1 & & & adult \\
\hline \multirow{6}{*}{$\begin{array}{l}\text { Horse/ } \\
\text { Donkey }\end{array}$} & \multirow{4}{*}{ Tunnel, central part } & Mandible & 8 & 1 & & & & \multirow{6}{*}{$\begin{array}{l}\text { probably from } 2 \\
\text { adult individuals }\end{array}$} \\
\hline & & Tooth & 5 & & & $\geq 2$ & & \\
\hline & & Metacarpal & 1 & & 1 & & & \\
\hline & & $\begin{array}{l}\text { Metacarpal or } \\
\text { Metatarsal }\end{array}$ & 2 & & 1 & & & \\
\hline & Tunnel, eastern part & Pelvis & 3 & 1 & & & & \\
\hline & Tunnel, western part & Pelvis & 1 & 1 & & & & \\
\hline \multirow{7}{*}{ Donkey } & \multirow{5}{*}{ Tunnel, western part } & Skull & 1 & & & 1 & & \multirow{7}{*}{1 adult individual } \\
\hline & & Tooth (Skull) & 1 & & 1 & & & \\
\hline & & Tooth (Mandible) & 1 & 1 & & & & \\
\hline & & Scapula & 2 & 1 & & & & \\
\hline & & Metacarpal & 1 & & 1 & & & \\
\hline & Tunnel, western part, top of fill & Tooth (Skull) & 1 & 1 & & & & \\
\hline & Tunnel, western part & Humerus & 8 & 1 & & & & \\
\hline \multirow{4}{*}{ Camel } & \multirow{3}{*}{ Tunnel, western part } & Mandible & 6 & 1 & 1 & & & \multirow{3}{*}{$\begin{array}{l}1 \text { individual: } \\
\text { female, adult }\end{array}$} \\
\hline & & Tooth & 11 & & & 1 & & \\
\hline & & Calcaneus & 1 & & 1 & & & \\
\hline & Robber pit & Talus & 1 & 1 & & & & $\begin{array}{l}\text { probably from the } \\
\text { above individual }\end{array}$ \\
\hline \multirow{4}{*}{ Gazelle } & Tunnel, central part & Metarsal & 3 & & & 1 & & \multirow{4}{*}{1 adult individual } \\
\hline & Tunnel, eastern part & Tibia & 4 & 1 & & & & \\
\hline & & Mandible & 1 & & 1 & & & \\
\hline & 1umer, weserin par & Tibia & 1 & & 1 & & & \\
\hline
\end{tabular}

PRODUCED BY U. IWASZCZUK 


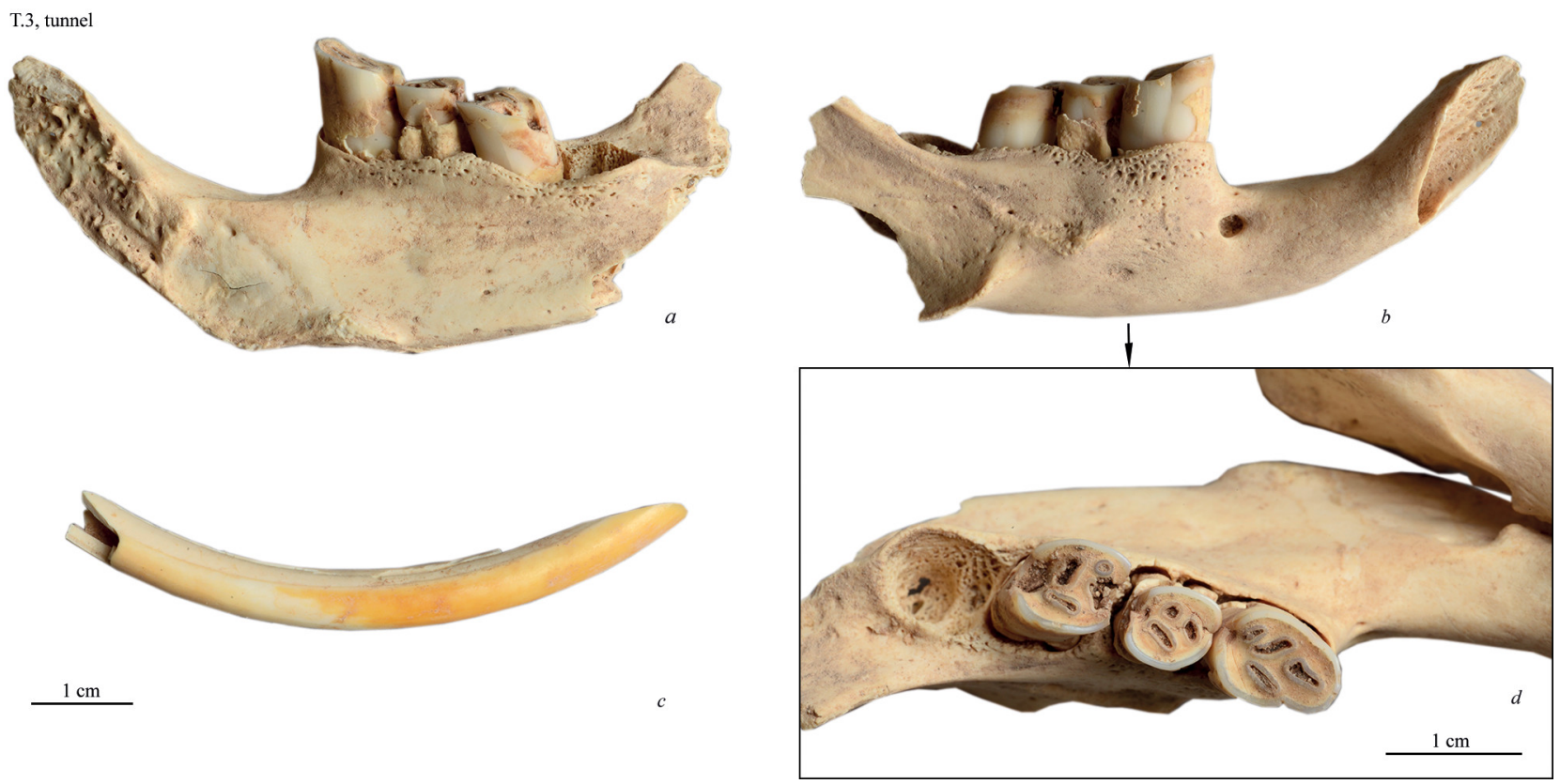

FIGURE 8.6 Porcupine mandible found in T.3 at El-Zuma PHOTOS BY A. KAMROWSKI

TABLE 8.3 Animal remains discovered in T.3

\begin{tabular}{|c|c|c|c|c|c|c|c|c|}
\hline \multirow[t]{2}{*}{ Species } & \multirow[t]{2}{*}{ Context } & \multirow[t]{2}{*}{ Bone } & \multirow{2}{*}{$\begin{array}{l}\text { Number of } \\
\text { fragments }\end{array}$} & \multicolumn{3}{|c|}{ Number of bones } & \multirow{2}{*}{$\begin{array}{l}\text { Marks left } \\
\text { by termites }\end{array}$} & \multirow[t]{2}{*}{ Description } \\
\hline & & & & Right & Left & Right/left & & \\
\hline \multirow{20}{*}{ Cattle } & Chamber 1 & Rib & 16 & & & 1 & & \multirow{6}{*}{1 individual: under 3.5 years old } \\
\hline & \multirow{5}{*}{ Chamber 2} & Tooth & 18 & & & 1 & & \\
\hline & & Rib & 4 & & & 3 & & \\
\hline & & Humerus & 6 & & 1 & & & \\
\hline & & Femur & 2 & & & 1 & & \\
\hline & & Patella & 1 & & & 1 & & \\
\hline & \multirow{2}{*}{ Niche } & Ribs & 2 & & & 1 & & \multirow{14}{*}{$\begin{array}{l}2 \text { individuals: } 1 \text { under } 3 \cdot 5^{-4} \text { years } \\
\text { old; } 1 \text { adult individual }\end{array}$} \\
\hline & & Humerus & 1 & & & 1 & & \\
\hline & \multirow{12}{*}{ Tunnel } & Mandible & 16 & 1 & & & & \\
\hline & & Sternum & 7 & & & 3 & & \\
\hline & & Rib & 31 & & & 3 & & \\
\hline & & Scapula & 6 & & & 1 & & \\
\hline & & Humerus & 3 & & 1 & & & \\
\hline & & Radius & 1 & & 1 & & & \\
\hline & & Ulna & 1 & & 1 & & & \\
\hline & & Ossa carpi & 1 & & & 1 & & \\
\hline & & Metacarpal & 21 & & 1 & & & \\
\hline & & Pelvis & 19 & 1 & 1 & & & \\
\hline & & Femur & 12 & 1 & 1 & & & \\
\hline & & Patella & 1 & & & 1 & & \\
\hline
\end{tabular}


TABLE 8.3 Animal remains discovered in T.3 (cont.)

\begin{tabular}{|c|c|c|c|c|c|c|c|c|}
\hline \multirow[t]{2}{*}{ Species } & \multirow[t]{2}{*}{ Context } & \multirow[t]{2}{*}{ Bone } & \multirow{2}{*}{$\begin{array}{l}\text { Number of } \\
\text { fragments }\end{array}$} & \multicolumn{3}{|c|}{ Number of bones } & \multirow{2}{*}{$\begin{array}{l}\text { Marks left } \\
\text { by termites }\end{array}$} & \multirow[t]{2}{*}{ Description } \\
\hline & & & & Right & Left & Right/left & & \\
\hline \multirow{7}{*}{ Cattle } & \multirow{3}{*}{ Tunnel } & Tibia & 1 & & 1 & & & \\
\hline & & Centroquartale & 2 & & & 1 & & \\
\hline & & Metatarsal & 2 & 1 & & & & \\
\hline & \multirow{4}{*}{ Robber pit } & Rib & 2 & & & 1 & & \multirow{4}{*}{ adult individual or individuals } \\
\hline & & Scapula & 22 & & 1 & & & \\
\hline & & Tibia & 2 & & 1 & & & \\
\hline & & Ph III & 1 & & 1 & & & \\
\hline \multirow{6}{*}{ Sheep } & \multirow{4}{*}{ Chamber 1} & Sternum & 29 & & & 7 & & \multirow{4}{*}{1 individual: about 3.5 years old } \\
\hline & & Rib & 43 & & & 4 & & \\
\hline & & Scapula & 9 & 1 & & & & \\
\hline & & Humerus & 11 & 1 & & & & \\
\hline & \multirow{2}{*}{ Tunnel } & Pelvis & 2 & & 1 & & & \multirow{2}{*}{ adult individual or individuals } \\
\hline & & Femur & 5 & & 1 & & & \\
\hline \multirow{3}{*}{ Ovicaprine } & \multirow{2}{*}{ Tunnel } & Scapula & 2 & & & 1 & & \multirow{3}{*}{ adult individual or individuals } \\
\hline & & Humerus & 3 & & & 1 & & \\
\hline & Robber pit & Rib & 3 & & & 1 & & \\
\hline \multirow{5}{*}{ Dog } & \multirow{5}{*}{ Robber pit } & Humerus & 9 & & 1 & & & \multirow{5}{*}{ adult individual or individuals } \\
\hline & & Ulna & 1 & & 1 & & & \\
\hline & & Femur & 1 & & 1 & & & \\
\hline & & Calcaneus & 1 & & 1 & & & \\
\hline & & Metatarsal & 1 & & 1 & & & \\
\hline Porcupine & Tunnel & Mandible & 7 & 1 & & & & old individual \\
\hline \multirow{3}{*}{ Micro-mammal } & Chombor & Femur & 1 & 1 & & & & \multirow{3}{*}{ adult individuals } \\
\hline & & Tibia & 1 & 1 & & & & \\
\hline & Tunnel & Tibia & 2 & 2 & & & & \\
\hline \multirow{2}{*}{ Bird } & \multirow{2}{*}{ Tunnel } & Vertebrae & 2 & & & 2 & & \multirow{2}{*}{ adult individual: pigeon size } \\
\hline & & Coracoid & 2 & & & 1 & & \\
\hline
\end{tabular}

PRODUCED BY U. IWASZCZUK

and bird remains. T.3 was the only type I tumulus analysed during this study that was found to contain animal bone elements in its burial chambers, though these were only partially excavated. Another two tumuli (T.2 and T.5) were analysed by Osypińska (2005; 2010); however, in these the distribution of animal bones differed significantly from that noted in the other tumuli at El-Zuma. The bones from the chambers in T.3 came from cattle and sheep exclusively, while in two papers published by Osypińska, she described camel bones found in the chambers of T.2 and T.5. This identification should be discussed here in the light of the photographs illustrating these two papers. Osypińska (2005, 407, Fig. 13) presented a cattle pelvis from T.2 bearing marks probably made during dismembering, but she identified it as a camel bone. A similar mistake concerns the material from T.5 (Osypińska 2010, 490, Fig. 3), where a cattle talus with skinning marks on it was described as a camel bone. It is probable that these two errors are simply the editor's mistakes, but as the presence of camel bones amongst food offerings has not been reported from Early Makurian graves, either in El-Zuma, El-Kassinger Bahry (Makowiecki 2007), Tanqasi (Osypiń- 

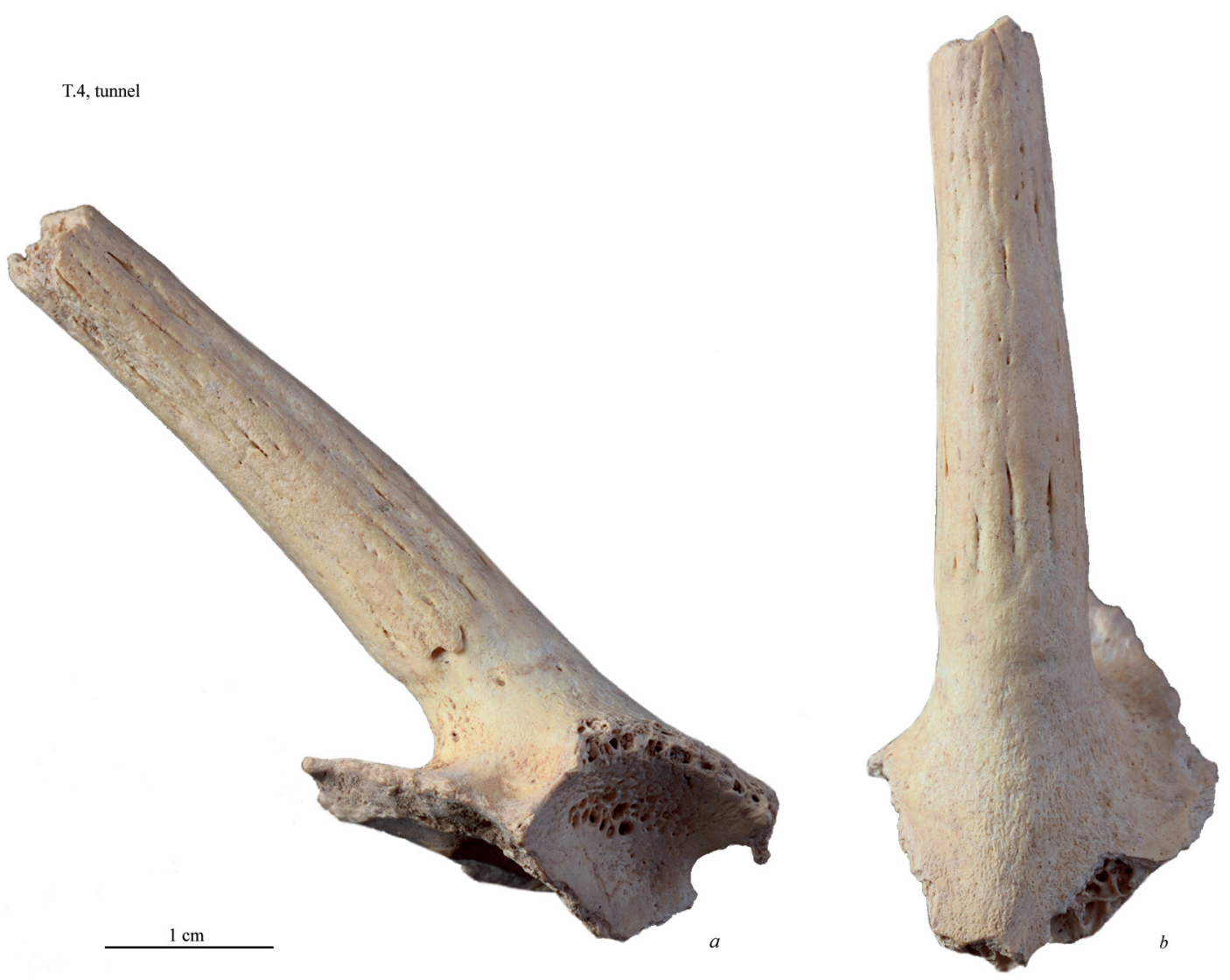

FIGURE 8.7 Fragment of skull with horncore of a dorcas gazelle found in T.4 at El-Zuma PHOTOS BY A. KAMROWSKI

ska 2008) or El-Detti (Iwaszczuk 2016), it is, therefore, also highly improbable in this context. These findings indicate that different sacrificial animals were used during rituals in T.2 and T.5, and therefore that a different group was conducting the sacrifices. Camel has never been mentioned as a sacrificial animal slaughtered for food offerings in Egyptian and Nubian history. The tradition of eating camel meat in Sudan is known nowadays only among nomadic groups in eastern Sudan (Mahmoud El-Tayeb, personal communication). Food offerings consisting of beef, on the other hand, were widespread in ancient Egypt (e.g. Ikram 1995) and have also been attested in Nubia (e.g. Chaix and Grant 1992). All other grave types in ElZuma analysed during this study contained only sheep or sheep and cattle remains as food offerings deposited in the burial chambers. Misidentification is therefore possible in the case of T.2 and T.5, or at least the presence of camel bones is uncertain in light of the doubts mentioned above.

\subsubsection{Tumulus 4}

The context of the discovery of $3,55^{1}$ animal bone fragments inside the tunnel of this tumulus has previously been discussed (Iwaszczuk, Niderla-Bielińska, and Ścieżyńska 2019, 7-21). It is, however, worth mentioning that the content of the tunnel fill, especially the artefacts and other finds extracted from the dark bottom layer (see Chapter 3.2, Fig. 3.28, this volume) (Mahmoud El-Tayeb $2017,340-346$ ), were exceptional in the context of the entire cemetery as well as other Early Makurian cemeteries (see Chapter 3, in this volume, and Volume III). The variety of mammal species found in this grave is also impressive [Table 8.4]. Except for the bones of cattle and sheep (which were the most popular sacrificial animals), elements of the skeletons of transport animals were also found, as well as the remains of a game animal (gazelle) [Fig. 8.7], which shows that the content was very similar to that of T.1. The very characteristic feature exclusive to this tumulus was the presence of almost-complete bat skeletons in the tunnel fill [Fig. 8.8], which will be discussed later. 

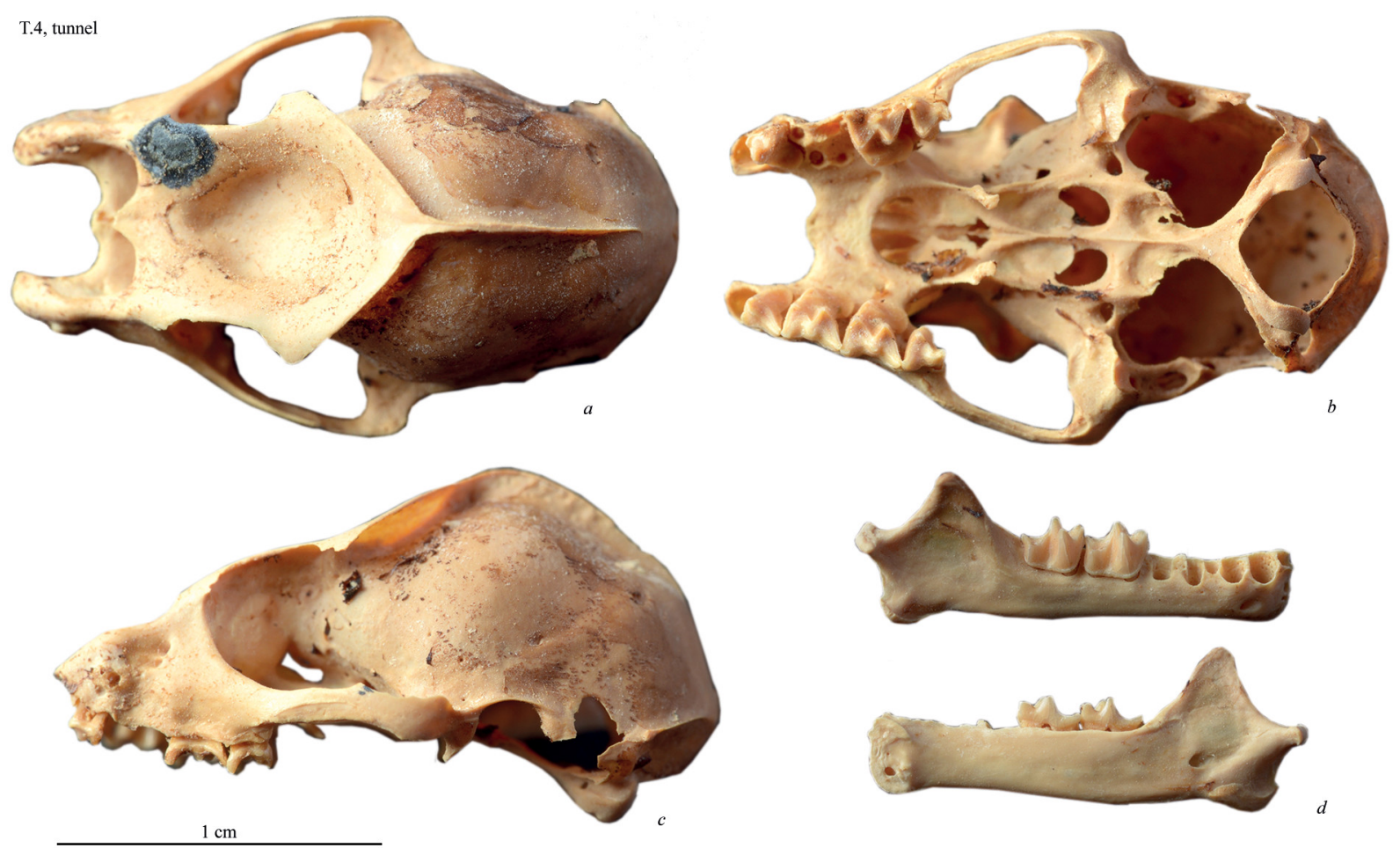

FIGURE 8.8 Bat head bone elements found in T.4 at El-Zuma: a-dorsal view of a skull, b-ventral view of a skull, c-lateral view of a skull, $d$ - buccal and lingual views of a mandible РнотOS BY А. KAMROWSKI

TABLE 8.4 Animal remains discovered in T.4

\begin{tabular}{|c|c|c|c|c|c|c|c|c|}
\hline \multirow[t]{2}{*}{ Species } & \multirow[t]{2}{*}{ Context } & \multirow[t]{2}{*}{ Bone } & \multirow{2}{*}{$\begin{array}{l}\text { Number of } \\
\text { fragments }\end{array}$} & \multicolumn{3}{|c|}{ Number of bones } & \multirow{2}{*}{$\begin{array}{l}\text { Marks left } \\
\text { by termites }\end{array}$} & \multirow[t]{2}{*}{ Description } \\
\hline & & & & Right & Left & Right/left & & \\
\hline \multirow{16}{*}{ Cattle } & \multirow{3}{*}{ Entrance to room W } & Thoracic vertebrae & 4 & & & 1 & & \multirow{16}{*}{$\begin{array}{l}3 \text { individuals: } 1 \\
\text { female, about } 3 \cdot 5^{-} \\
4 \text { years old; } 1 \text { male, } \\
\text { more than } 3-3 \cdot 5 \\
\text { years old; } 1 \text { young } \\
\text { individual, between } \\
15 \text { and } 20 \text { months ol }\end{array}$} \\
\hline & & Femur & 10 & 1 & & & & \\
\hline & & Talus & 1 & & 1 & & & \\
\hline & \multirow{13}{*}{ Tunnel, eastern part } & Skull & 9 & & & 1 & & \\
\hline & & Mandible & 105 & 1 & 3 & & & \\
\hline & & Tooth & 171 & & 1 & $\geq 4$ & & \\
\hline & & Cervical vertebrae & 1 & & & 1 & & \\
\hline & & Lumbar vertebrae & 5 & & & 3 & & \\
\hline & & Rib & 45 & 2 & & & & \\
\hline & & Scapula & 24 & 2 & 1 & & & \\
\hline & & Humerus & 16 & 2 & 2 & & & \\
\hline & & Radius & 18 & 2 & 1 & 1 & & \\
\hline & & Ulna & 3 & 1 & 1 & & & \\
\hline & & Metacarpal & 11 & 1 & 1 & 1 & & \\
\hline & & Metacarpal or Metatarsal & 1 & & & 1 & & \\
\hline & & Pelvis & 4 & 1 & 1 & & & \\
\hline
\end{tabular}


TABLE 8.4 Animal remains discovered in T.4 (cont.)

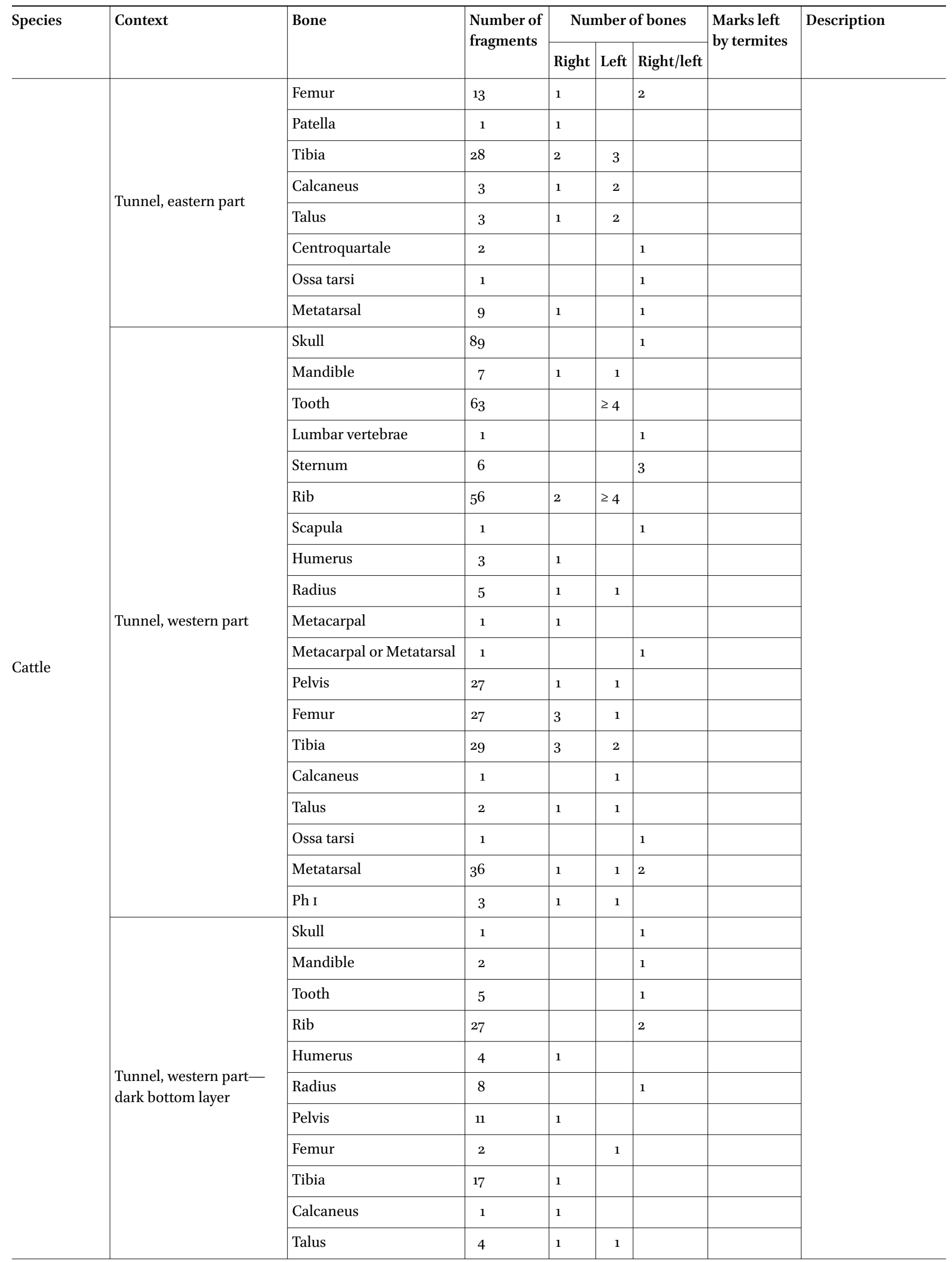


TABLE 8.4 Animal remains discovered in T.4 (cont.)

\begin{tabular}{|c|c|c|c|c|c|c|c|c|}
\hline \multirow[t]{2}{*}{ Species } & \multirow[t]{2}{*}{ Context } & \multirow[t]{2}{*}{ Bone } & \multirow{2}{*}{$\begin{array}{l}\text { Number of } \\
\text { fragments }\end{array}$} & \multicolumn{3}{|c|}{ Number of bones } & \multirow{2}{*}{$\begin{array}{l}\text { Marks left } \\
\text { by termites }\end{array}$} & \multirow[t]{2}{*}{ Description } \\
\hline & & & & Right & Left & Right/left & & \\
\hline \multirow{9}{*}{ Sheep } & \multirow{6}{*}{ Tunnel, eastern part } & Skull & 6 & & & 1 & & \multirow{9}{*}{$\begin{array}{l}2 \text { individuals: } 1 \text { under } \\
5 \text { months old; } 1 \\
\text { between } 5 \text { months } \\
\text { and } 3-3.5 \text { years old }\end{array}$} \\
\hline & & Mandible & 20 & & 1 & & & \\
\hline & & Scapula & 1 & & 1 & & & \\
\hline & & Radius & 9 & 1 & & & & \\
\hline & & Femur & 1 & & 1 & & & \\
\hline & & Talus & 1 & & 1 & & & \\
\hline & \multirow{2}{*}{ Tunnel, western part } & Femur & 1 & & 1 & & & \\
\hline & & Talus & 2 & 2 & & & & \\
\hline & $\begin{array}{l}\text { Tunnel, western part- } \\
\text { dark bottom layer }\end{array}$ & Scapula & 9 & & 1 & & & \\
\hline \multirow{5}{*}{ Goat } & \multirow{5}{*}{ Tunnel, western part } & Skull & 2 & & & 1 & & \multirow{5}{*}{$\begin{array}{l}1 \text { individual: between } \\
2 \text { and } 3 \text { years old }\end{array}$} \\
\hline & & Atlas & 1 & & & 1 & & \\
\hline & & Humerus & 1 & 1 & & & & \\
\hline & & Calcaneus & 1 & 1 & & & & \\
\hline & & Metacarpal or Metatarsal & 1 & & & 1 & & \\
\hline \multirow{22}{*}{ Ovicaprine } & \multirow{16}{*}{ Tunnel, eastern part } & Skull & 22 & & & 1 & & \multirow{22}{*}{$\begin{array}{l}\text { probably from the } \\
\text { above sheep and goat }\end{array}$} \\
\hline & & Tooth (Skull) & 4 & & 1 & & & \\
\hline & & Tooth (Mandible) & 1 & & 1 & & & \\
\hline & & Tooth & 19 & & & $\geq 7$ & & \\
\hline & & Sacrum & 1 & & & 1 & & \\
\hline & & Rib & 9 & & & 2 & & \\
\hline & & Scapula & 4 & 1 & 1 & & & \\
\hline & & Humerus & 3 & & 1 & & & \\
\hline & & Radius & 6 & & 1 & & & \\
\hline & & Ossa carpi & 4 & & & 4 & & \\
\hline & & Femur & 2 & & 1 & & & \\
\hline & & Tibia & 7 & & & 2 & present & \\
\hline & & Calcaneus & 1 & & & 1 & & \\
\hline & & Ossa tarsi & 1 & & & 1 & & \\
\hline & & Metatarsal & 8 & 1 & & 1 & $\begin{array}{l}\text { present on } 4 \\
\text { fragments }\end{array}$ & \\
\hline & & Ph I & 1 & 1 & & & & \\
\hline & Entrance to room W & Cervical vertebrae & 1 & & & 1 & & \\
\hline & \multirow{5}{*}{ Tunnel, western part } & Skull & 5 & & & 1 & & \\
\hline & & Mandible & 6 & & 1 & 1 & & \\
\hline & & Tooth (Skull) & 3 & & & 1 & & \\
\hline & & Tooth (Mandible) & 10 & & 1 & 2 & & \\
\hline & & Tooth & 9 & & & 5 & & \\
\hline
\end{tabular}


TABLE 8.4 Animal remains discovered in T.4 (cont.)

\begin{tabular}{|c|c|c|c|c|c|c|c|c|}
\hline \multirow[t]{2}{*}{ Species } & \multirow[t]{2}{*}{ Context } & \multirow[t]{2}{*}{ Bone } & \multirow{2}{*}{$\begin{array}{l}\text { Number of } \\
\text { fragments }\end{array}$} & \multicolumn{3}{|c|}{ Number of bones } & \multirow{2}{*}{$\begin{array}{l}\text { Marks left } \\
\text { by termites }\end{array}$} & \multirow[t]{2}{*}{ Description } \\
\hline & & & & Right & Left & Right/left & & \\
\hline \multirow{16}{*}{ Ovicaprine } & \multirow{13}{*}{ Tunnel, western part } & Cervical vertebrae & 1 & & & 1 & & \\
\hline & & Sternum & 2 & & & 2 & & \\
\hline & & Rib & 55 & 5 & 3 & 2 & & \\
\hline & & Scapula & 6 & & & 1 & & \\
\hline & & Humerus & 2 & 1 & & 1 & & \\
\hline & & Radius & 1 & & 1 & & & \\
\hline & & Metacarpal & 1 & & 1 & & & \\
\hline & & Pelvis & 2 & & & 1 & & \\
\hline & & Femur & 1 & & & 1 & & \\
\hline & & Patella & 1 & & 1 & & & \\
\hline & & Tibia & 13 & 1 & & 1 & & \\
\hline & & Calcaneus & 1 & & 1 & & & \\
\hline & & Metatarsal & 2 & & & 1 & & \\
\hline & \multirow{3}{*}{$\begin{array}{l}\text { Tunnel, western part- } \\
\text { dark bottom layer }\end{array}$} & Mandible & 4 & & & 1 & & \\
\hline & & Lumbar vertebrae & 2 & & & 1 & & \\
\hline & & Metacarpal & 1 & & & 1 & & \\
\hline \multirow{10}{*}{ Donkey } & \multirow{5}{*}{ Tunnel, eastern part } & Humerus & 2 & 1 & 1 & & & \multirow{10}{*}{1 individual: adult } \\
\hline & & Metacarpal & 2 & & & 1 & & \\
\hline & & Femur & 5 & 1 & 1 & & & \\
\hline & & Tibia & 3 & & 1 & & & \\
\hline & & $\mathrm{Ph}$ I & 1 & & 1 & & & \\
\hline & \multirow{2}{*}{ Entrance to room W } & Rib & 5 & 1 & & & & \\
\hline & & Pelvis & 17 & 1 & & & & \\
\hline & \multirow{3}{*}{ Tunnel, western part } & Radius & 2 & & 1 & & & \\
\hline & & Ulna & 1 & 1 & & & & \\
\hline & & Ossa carpi & 1 & & 1 & & & \\
\hline \multirow{11}{*}{ Camel } & \multirow{9}{*}{ Tunnel, eastern part } & Skull & 8 & & & 1 & & \multirow{11}{*}{$\begin{array}{l}2 \text { individuals: } 1 \\
\text { almost adult; } 1 \text { adult }\end{array}$} \\
\hline & & Mandible & 3 & 2 & 1 & & & \\
\hline & & Thoracic vertebrae & 1 & & & 1 & & \\
\hline & & Lumbar vertebrae & 1 & & & 1 & & \\
\hline & & Rib & 20 & 3 & & & & \\
\hline & & Scapula & 2 & 1 & 1 & & & \\
\hline & & Humerus & 3 & & 1 & & & \\
\hline & & Femur & 1 & 1 & & & & \\
\hline & & Metatarsal & 4 & & 1 & & & \\
\hline & \multirow{2}{*}{ Tunnel, western part } & Mandible & 4 & & & 1 & & \\
\hline & & Scapula & 16 & & 1 & & & \\
\hline
\end{tabular}


TABLE 8.4 Animal remains discovered in T.4 (cont.)

\begin{tabular}{|c|c|c|c|c|c|c|c|c|}
\hline \multirow[t]{2}{*}{ Species } & \multirow[t]{2}{*}{ Context } & \multirow[t]{2}{*}{ Bone } & \multirow{2}{*}{$\begin{array}{l}\text { Number of } \\
\text { fragments }\end{array}$} & \multicolumn{3}{|c|}{ Number of bones } & \multirow{2}{*}{$\begin{array}{l}\text { Marks left } \\
\text { by termites }\end{array}$} & \multirow[t]{2}{*}{ Description } \\
\hline & & & & Right & Left & Right/left & & \\
\hline \multirow{3}{*}{ Camel } & \multirow{3}{*}{ Tunnel, western part } & Centroquartale & 2 & 1 & & & & \\
\hline & & Calcaneus & 1 & 1 & & & & \\
\hline & & Metatarsal & 5 & 1 & & & & \\
\hline Gazelle & Tunnel, eastern part & Humerus & 8 & & 1 & & & adult \\
\hline Dorcas gazelle & Tunnel, western part & Skull & 1 & & & & & female \\
\hline Carnivore & Tunnel, eastern part & Lumbar vertebrae & 1 & & & 1 & & adult \\
\hline Carnivore & Tunnel, western part & Rib & 2 & & & 2 & & 1 individual \\
\hline Dog & Tunnel, eastern part & Lumbar vertebrae & 2 & & & 1 & & young \\
\hline \multirow{30}{*}{ Bat } & \multirow{18}{*}{$\begin{array}{l}\text { Tunnel, eastern part, top } \\
\text { of fill }\end{array}$} & Skull & 14 & & & 5 & & \multirow{18}{*}{5 individuals: adult } \\
\hline & & Mandible & 15 & 4 & 3 & & & \\
\hline & & Atlas & 2 & & & 2 & & \\
\hline & & Cervical vertebrae & 10 & & & 10 & & \\
\hline & & Thoracic vertebrae & 2 & & & 2 & & \\
\hline & & Lumbar vertebrae & 4 & & & 4 & & \\
\hline & & Rib & 28 & & & 28 & & \\
\hline & & Clavicle & 1 & & 1 & & & \\
\hline & & Scapula & 3 & 1 & 2 & & & \\
\hline & & Humerus & 6 & 3 & 3 & & & \\
\hline & & Radius & 3 & 1 & 1 & & & \\
\hline & & Ulna & 8 & 3 & 2 & 1 & & \\
\hline & & Metacarpal & 1 & & & 1 & & \\
\hline & & Pelvis & 3 & & & 3 & & \\
\hline & & Femur & 2 & 1 & & & & \\
\hline & & Tibia & 3 & 2 & 1 & & & \\
\hline & & Metatarsal & 2 & & & 2 & & \\
\hline & & Fragments of long bones & 15 & & & 15 & & \\
\hline & \multirow{12}{*}{ Tunnel, eastern part } & Skull & 2 & & & 2 & & \multirow{12}{*}{3 individuals: adult } \\
\hline & & Mandible & 4 & 2 & 2 & & & \\
\hline & & Atlas & 2 & & & 2 & & \\
\hline & & Axis & 2 & & & 2 & & \\
\hline & & Cervical vertebrae & 8 & & & 8 & & \\
\hline & & Thoracic vertebrae & 4 & & & 4 & & \\
\hline & & Lumbar vertebrae & 4 & & & 4 & & \\
\hline & & Sternum & 2 & & & 2 & & \\
\hline & & Clavicle & 1 & & & 1 & & \\
\hline & & Rib & 26 & & & 26 & & \\
\hline & & Scapula & 4 & 2 & 2 & & & \\
\hline & & Humerus & 4 & 2 & 2 & & & \\
\hline
\end{tabular}


TABLE 8.4 Animal remains discovered in T.4 (cont.)

\begin{tabular}{|c|c|c|c|c|c|c|c|c|}
\hline \multirow[t]{2}{*}{ Species } & \multirow[t]{2}{*}{ Context } & \multirow[t]{2}{*}{ Bone } & \multirow{2}{*}{$\begin{array}{l}\text { Number of } \\
\text { fragments }\end{array}$} & \multicolumn{3}{|c|}{ Number of bones } & \multirow{2}{*}{$\begin{array}{l}\text { Marks left } \\
\text { by termites }\end{array}$} & \multirow[t]{2}{*}{ Description } \\
\hline & & & & Right & Left & Right/left & & \\
\hline \multirow{27}{*}{ Bat } & \multirow{8}{*}{ Tunnel, eastern part } & Radius & 2 & & & 1 & & \\
\hline & & Ulna & 6 & 2 & 3 & & & \\
\hline & & Metacarpal & 10 & & & 8 & & \\
\hline & & Pelvis & 2 & 1 & 1 & & & \\
\hline & & Femur & 5 & 2 & 2 & & & \\
\hline & & Metatarsal & 1 & & & 1 & & \\
\hline & & Ph I & 1 & & & 1 & & \\
\hline & & Fragments of long bones & 10 & & & 10 & & \\
\hline & \multirow{15}{*}{$\begin{array}{l}\text { Tunnel, western part, top } \\
\text { of fill }\end{array}$} & Skull & 4 & & & 1 & & \multirow{15}{*}{1 individual: adult } \\
\hline & & Mandible & 4 & 1 & 1 & & & \\
\hline & & Cervical vertebrae & 4 & & & 4 & & \\
\hline & & Thoracic vertebrae & 3 & & & 3 & & \\
\hline & & Sacrum & 1 & & & 1 & & \\
\hline & & Sternum & 1 & & & 1 & & \\
\hline & & Rib & 12 & & & 12 & & \\
\hline & & Scapula & 4 & 1 & 1 & & & \\
\hline & & Humerus & 2 & 1 & 1 & & & \\
\hline & & Ulna & 3 & 1 & 1 & & & \\
\hline & & Metacarpal & 2 & & & 2 & & \\
\hline & & Pelvis & 2 & & & 1 & & \\
\hline & & Tibia & 2 & 1 & 1 & & & \\
\hline & & Ph I & 1 & & & 1 & & \\
\hline & & Fragments of long bones & 27 & & & 27 & & \\
\hline & \multirow{4}{*}{ Tunnel, western part } & Skull & 2 & & & 1 & & \multirow{4}{*}{2 individuals: adult } \\
\hline & & Mandible & 1 & & 1 & & & \\
\hline & & Humerus & 3 & 1 & 2 & & & \\
\hline & & Ulna & 3 & 1 & 1 & & & \\
\hline
\end{tabular}

PRODUCED BY U. IWASZCZUK

\subsubsection{Tumulus 6}

A total of 176 remains were discovered in this tumulus. Only 16 fragments remain unidentified. The bones were found within two structures: the shaft and the tunnel, but the remains from the tunnel were much more numerous than those from the shaft [Table 8.5]. There were only 4 ovicaprine remains (from the thorax and the proximal parts of the limbs) in the shaft. The bone material from the tunnel was similar in species variety to that noted in T.3. Remains of cattle, ovicaprine, donkey, small rodents, and a bird of pigeon size were discovered in the tun- nel. The cattle, ovicaprine, and donkey bones came from adult individuals. Cattle remains were represented almost exclusively by cranial elements (only 2 other bones were recorded there: a carpal and tibia). Donkey and ovicaprine remains were very scarce. The first of these species was represented solely by a third phalanx, and the second by a solitary fragment of femur. The tunnel must have been open for some time (after the funeral? after the robbery?) because in both corridors of the tunnel, and at the front of that structure, there were incomplete skeletons of small rodents. The bones of one of them could be identified 
TABLE 8.5 Animal remains discovered in T.6

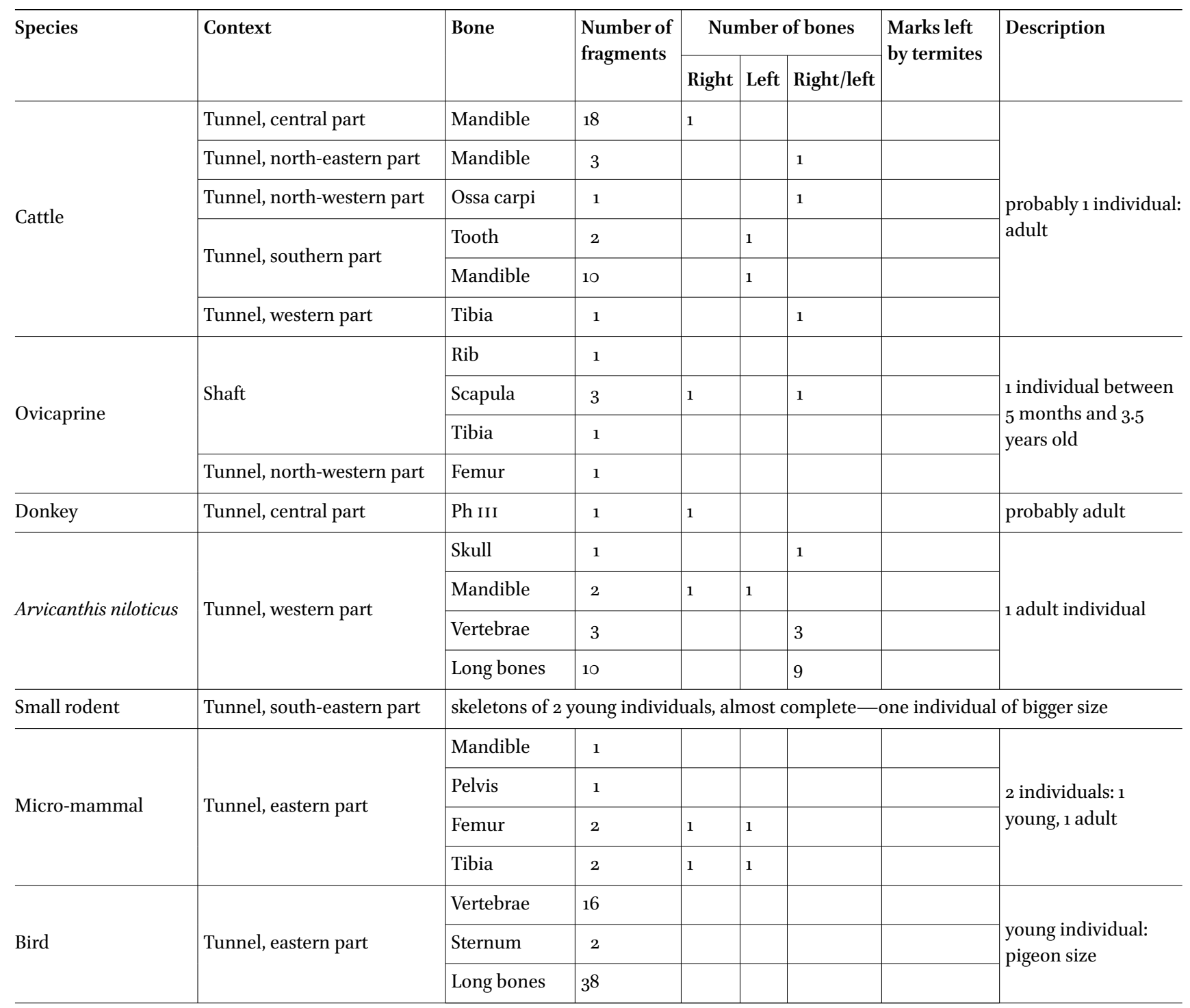

PRODUCED BY U. IWASZCZUK

to species as Arvicanthis niloticus; the two others (almost complete) were not determined.

\subsubsection{Tumulus 7}

The content of T.7 was very typical of type I tumuli. All of the remains, 329 fragments, were found in the tunnel. The faunal material has already been analysed (Iwaszczuk, Niderla-Bielińska, and Ścieżyńska 2019, 7-21), and it seems that the zoological and anatomical distribution of the remains [Table 8.6] is very similar to the distribution of the remains recovered from T.1, T.3, T.6, and T.8. Some of the cattle bones bore evidence of filleting (ribs) [Fig. 8.9].
4.1.6 Tumulus 8

There were 388 fragments of animal bones found in T.8; unfortunately, 88 of that number could not be identified. The remains were discovered in chamber 1 , in the tunnel and in the robber pit. Chamber 1 yielded the bones of two cattle individuals (one aged about 2-2.5 years and the other an adult), as well as two sheep individuals (one aged 2-2.5 years and the other an adult). The withers height of the cattle was estimated at $111 \mathrm{~cm}$ and the sheep withers height at $53.5 \mathrm{~cm}$. The remains of both species came from the thorax and proximal parts of limbs. Also some cattle and sheep bones from the same parts of the carcasses were found in the tunnel. They probably came from the same animals as the bones deposited in chamber 1. Additionally, the head bones and a large part of the thorax of an ovicaprine found in the tunnel belonged to an indi- 
TABLE 8.6 Animal remains discovered in T.7

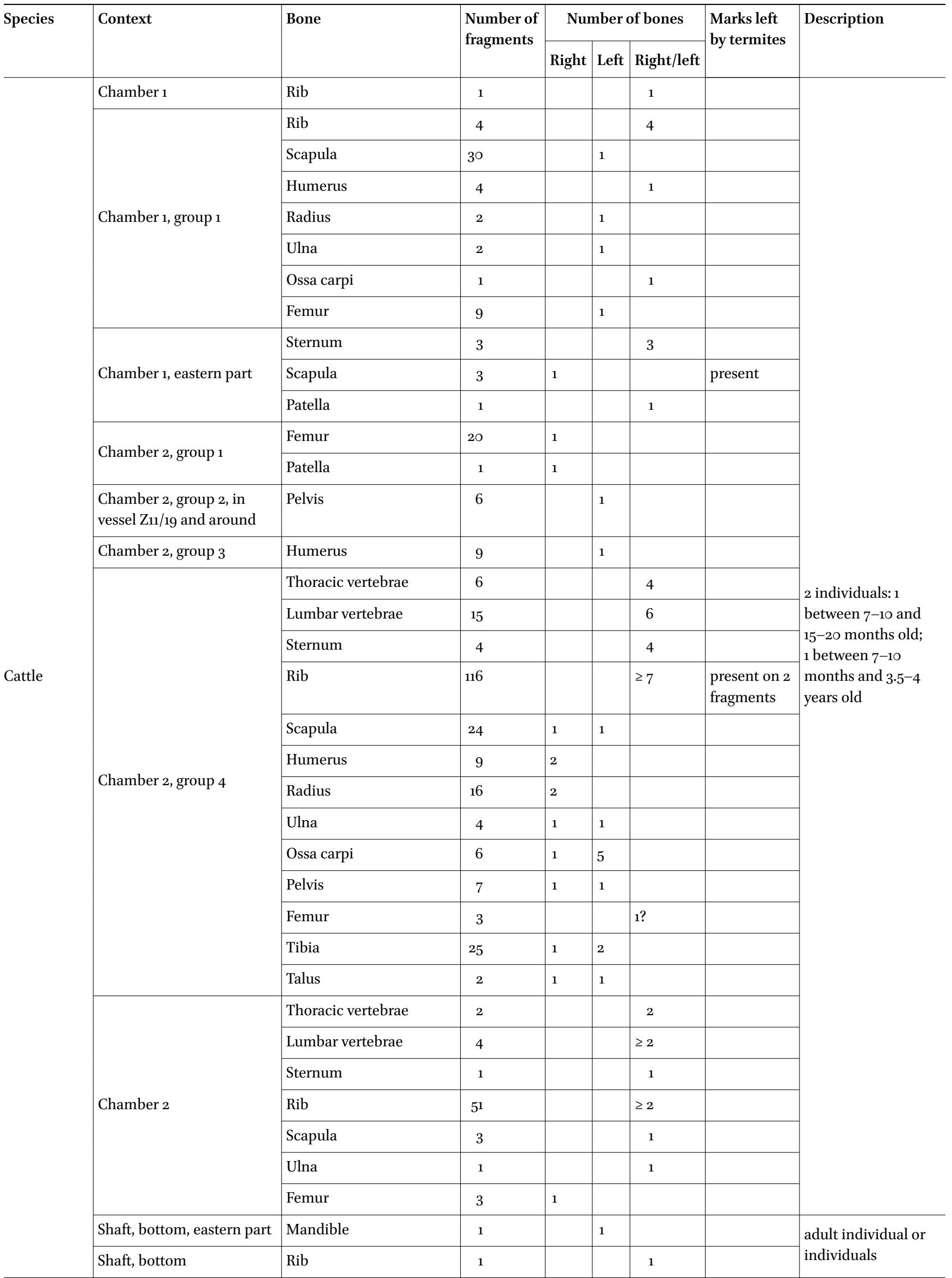


TABLE 8.6 Animal remains discovered in T.7 (cont.)

\begin{tabular}{|c|c|c|c|c|c|c|c|c|}
\hline \multirow[t]{2}{*}{ Species } & \multirow[t]{2}{*}{ Context } & \multirow[t]{2}{*}{ Bone } & \multirow{2}{*}{$\begin{array}{l}\text { Number of } \\
\text { fragments }\end{array}$} & \multicolumn{3}{|c|}{ Number of bones } & \multirow{2}{*}{$\begin{array}{l}\text { Marks left } \\
\text { by termites }\end{array}$} & \multirow[t]{2}{*}{ Description } \\
\hline & & & & Right & Left & Right/left & & \\
\hline \multirow{13}{*}{ Sheep } & \multirow{2}{*}{ Chamber 1} & Radius & 1 & & 1 & & & \multirow{13}{*}{$\begin{array}{l}2 \text { individuals: } 1 \text { under } \\
3-4 \text { months old; } 1 \\
\text { adult }\end{array}$} \\
\hline & & Calcaneus & 1 & & 1 & & & \\
\hline & \multirow{3}{*}{ Chamber 1, eastern part } & Scapula & 4 & 1 & & & & \\
\hline & & Radius & 1 & 1 & & & & \\
\hline & & Femur & 8 & 1 & & & & \\
\hline & Chamber 1 , group 1 & Humerus & 2 & & 1 & & & \\
\hline & Chamber 2, group 3 & Calcaneus & 1 & 1 & & & & \\
\hline & \multirow{3}{*}{ Chamber 2, group 4} & Humerus & 2 & 2 & & & & \\
\hline & & Radius & 2 & 1 & 1 & & & \\
\hline & & Pelvis & 1 & 1 & & & & \\
\hline & Chamber 2, in vessel 14 & Pelvis & 5 & 1 & & & & \\
\hline & \multirow{2}{*}{ Chamber 2} & Talus & 1 & 1 & & & & \\
\hline & & Tibia & 1 & 1 & & & & \\
\hline \multirow{25}{*}{ Ovicaprine } & Chamber 1 & Femur & 1 & & & 1 & & \multirow{25}{*}{$\begin{array}{l}2 \text { individuals: } 1 \\
\text { between } 5 \text { months } \\
\text { and } 3.5 \text { years old; } 1 \\
\text { under } 15^{-20} \text { months, } \\
\text { probably remains } \\
\text { from the young } \\
\text { sheep above }\end{array}$} \\
\hline & \multirow{10}{*}{ Chamber 1, eastern part } & Cervical vertebrae & 2 & & & 1 & & \\
\hline & & Lumbar vertebrae & 2 & & & 1 & & \\
\hline & & Sternum & 1 & & & 1 & & \\
\hline & & Humerus & 1 & & & 1 & & \\
\hline & & Ulna & 1 & & & 1 & & \\
\hline & & Metacarpal & 2 & & & $2 ?$ & & \\
\hline & & Ossa carpi & 1 & & & 1 & & \\
\hline & & Femur & 5 & & & $1 ?$ & & \\
\hline & & Tibia & 1 & & 1 & & & \\
\hline & & Calcaneus & 1 & & & 1 & & \\
\hline & \multirow{4}{*}{ Chamber 1 , group 1} & Sternum & 1 & & & 1 & & \\
\hline & & Radius & 1 & & 1 & & & \\
\hline & & Femur & 8 & & 1 & & & \\
\hline & & Tibia & 2 & & 1 & & & \\
\hline & \multirow{2}{*}{ Chamber 2, group 3} & Rib & 2 & & & 1 & & \\
\hline & & Pelvis & 1 & & & 1 & & \\
\hline & \multirow{8}{*}{ Chamber 2, group 4} & Cervical vertebrae & 1 & & & 1 & & \\
\hline & & Thoracic vertebrae & 3 & & & 3 & & \\
\hline & & Lumbar vertebrae & 4 & & & 1 & & \\
\hline & & Rib & 26 & & & $1 ?$ & & \\
\hline & & Radius & 1 & & & 1 & & \\
\hline & & Ulna & 2 & 1 & & & & \\
\hline & & Ossa carpi & 2 & 2 & & & & \\
\hline & & Pelvis & 3 & 1 & 1 & & & \\
\hline
\end{tabular}


TABLE 8.6 Animal remains discovered in T.7 (cont.)

\begin{tabular}{|c|c|c|c|c|c|c|c|c|}
\hline \multirow[t]{2}{*}{ Species } & \multirow[t]{2}{*}{ Context } & \multirow[t]{2}{*}{ Bone } & \multirow{2}{*}{$\begin{array}{l}\text { Number of } \\
\text { fragments }\end{array}$} & \multicolumn{3}{|c|}{ Number of bones } & \multirow{2}{*}{$\begin{array}{l}\text { Marks left } \\
\text { by termites }\end{array}$} & \multirow[t]{2}{*}{ Description } \\
\hline & & & & Right & Left & Right/left & & \\
\hline \multirow{10}{*}{ Ovicaprine } & \multirow{2}{*}{ Chamber 2, group 4} & Tibia & 6 & & & $1 ?$ & & \\
\hline & & Ossa tarsi & 1 & 1 & & & & \\
\hline & \multirow{6}{*}{ Chamber 2} & Rib & 25 & & & 1 & & \\
\hline & & Humerus & 4 & & & 1 & & \\
\hline & & Radius & 1 & & & 1 & & \\
\hline & & Femur & 3 & & & $1 ?$ & & \\
\hline & & Tibia & 5 & 1 & & & & \\
\hline & & Ossa tarsi & 1 & & & 1 & & \\
\hline & \multirow{2}{*}{ Shaft, bottom } & Rib & 14 & & & $\geq 3$ & & \multirow{2}{*}{$\begin{array}{l}\text { adult individual or } \\
\text { individuals }\end{array}$} \\
\hline & & Humerus & 3 & & & 1 & & \\
\hline
\end{tabular}

PRODUCED BY U. IWASZCZUK

vidual or individuals under $3-3.5$ years old. Two fragments of goat ulna were deposited in the tunnel. Goat bones have rarely been discovered in the El-Zuma graves and might be regarded as an intrusive deposit. Some bones of adult sheep, ovicaprines, and birds of pigeon size were also recovered from the robber pit [Table 8.7]. It seems that they were not connected with the funerary rituals as they were found in the mixed earth and gravel of the robber pit.

\subsection{Type II Tumuli}

The discovery context of the animal bones in type II tumuli has already been discussed in the case of some tumuli (Iwaszczuk, Niderla-Bielińska, and Ścieżyńska 2019, 21-23; Iwaszczuk 2015, 427-428). Two other tumuli of this type, T.10 and T.25, were analysed by Osypińska (2010), as mentioned earlier.

\subsubsection{Tumulus 9}

The majority of animal remains were discovered in the central and southern part of chamber 1, though some remains were also excavated in the robber pit [Table 8.8]. Bones found in the chamber had been moved from their original positions and mixed with human remains. All of these bones ( 36 fragments in total) could be identified. The material consisted of ovicaprine remains exclusively. Only 15 fragments from 5 bones were found in the chamber. They represented parts of the carcass with goodquality meat: the thorax and proximal parts of the limbs of a relatively young animal. None of the bones bore postconsumption or other marks. Additionally, 21 fragments of two ovicaprine bones (a mandible and tooth) were discovered in the robber pit, which suggests that they were probably not connected with the funerary ritual and undoubtedly got there after the superstructure had been built above the grave.

\subsubsection{Tumulus 11}

Animal bones were concentrated in one group in chamber 1 and in four clusters in chamber 2, but some bones were also found in other parts of these chambers. A small number of the remains, only 19 fragments, were also found at the bottom of the shaft [Table 8.9]. Altogether, 1,362 bone and tooth fragments were analysed; unfortunately, a large number of them (794 fragments) could not be identified to species because they lacked diagnostic features.

The remains discovered in the chambers came from 2 individuals: one was aged between $7^{-10}$ and $15^{-20}$ months, the other one was a little older (it was only possible to estimate the age to within a broad range of between 7-10 months and 3.5-4 years). Sheep bones also came from 2 individuals: the first one was very young, less than 3-4 months old, and the other was an adult. Other remains of ovicaprines belonged to 2 individuals: one of them was under $15^{-20}$ months (it is probable that these remains came from the young sheep mentioned above); the other one was older-between 5 months and 3.5 years old. All remains found in the shaft belonged to adult animals.

Cattle and ovicaprine remains were located in a cluster in the western part of chamber 1. Cattle bones were more numerous: there were $5^{2}$ fragments from 10 bones of the thorax and proximal parts of the limbs. In this group there were also ovicaprine remains representing the same body parts as the cattle remains. One of these bones 
TABLE 8.7 Animal remains discovered in T.8

\begin{tabular}{|c|c|c|c|c|c|c|c|c|}
\hline \multirow[t]{2}{*}{ Species } & \multirow[t]{2}{*}{ Context } & \multirow[t]{2}{*}{ Bone } & \multirow{2}{*}{$\begin{array}{l}\text { Number of } \\
\text { fragments }\end{array}$} & \multicolumn{3}{|c|}{ Number of bones } & \multirow{2}{*}{$\begin{array}{l}\text { Marks left } \\
\text { by termites }\end{array}$} & \multirow[t]{2}{*}{ Description } \\
\hline & & & & Right & Left & Right/left & & \\
\hline \multirow{15}{*}{ Cattle } & \multirow{5}{*}{ Chamber 1} & Ribs & 15 & & & 3 & & \multirow{15}{*}{$\begin{array}{l}2 \text { individuals: } 1 \text { about } \\
2-2.5 \text { years old, } 1 \text { adult }\end{array}$} \\
\hline & & Scapula & 9 & & 1 & & & \\
\hline & & Femur & 4 & & 1 & 1 & & \\
\hline & & Patella & 1 & & 1 & & & \\
\hline & & Tibia & 12 & & 1 & & & \\
\hline & \multirow{10}{*}{ Tunnel } & Cervical vertebrae & 3 & & & 3 & & \\
\hline & & Ribs & 6 & & & 3 & & \\
\hline & & Scapula & 111 & 1 & & & & \\
\hline & & Humerus & 8 & 1 & 1 & & & \\
\hline & & Radius & 12 & & 1 & & & \\
\hline & & Ossa carpi & 4 & & & 4 & & \\
\hline & & Femur & 1 & 1 & & & & \\
\hline & & Tibia & 1 & & & 1 & & \\
\hline & & Talus & 1 & & 1 & & & \\
\hline & & $\mathrm{Ph} \mathrm{I}$ & 1 & & & 1 & & \\
\hline \multirow{11}{*}{ Sheep } & \multirow{6}{*}{ Chamber 1} & Thoracic vertebrae & 3 & & & 1 & & \multirow{6}{*}{$\begin{array}{l}2 \text { individuals: } 1 \text { indi- } \\
\text { vidual between } 15^{-20} \\
\text { months and } 3.5 \text { years } \\
\text { old, } 1 \text { adult individual }\end{array}$} \\
\hline & & Ribs & 1 & & & 1 & & \\
\hline & & Humerus & 9 & 1 & & & & \\
\hline & & Radius & 2 & 1 & & & & \\
\hline & & Femur & 11 & 1 & & & & \\
\hline & & Tibia & 3 & & 1 & & & \\
\hline & \multirow{4}{*}{ Tunnel } & Scapula & & 2 & & & & \multirow{4}{*}{$\begin{array}{l}1 \text { individual under } 3^{-} \\
3.5 \text { years old }\end{array}$} \\
\hline & & Humerus & 4 & 1 & & & & \\
\hline & & Radius & 3 & 2 & & & & \\
\hline & & Ulna & 1 & 1 & & & & \\
\hline & Robber pit & Calcaneus & 1 & 1 & & & & adult individual \\
\hline Goat & Tunnel & Ulna & 2 & 1 & & & & adult individual \\
\hline \multirow{12}{*}{ Ovicaprine } & \multirow{12}{*}{ Tunnel } & Skull & 1 & & & 1 & & \multirow{12}{*}{$\begin{array}{l}2 \text { individual: } 1 \text { under } \\
3-3.5 \text { years old, } 1 \text { adult } \\
\text { (only } 2 \text { lumbar verteb- } \\
\text { rae) }\end{array}$} \\
\hline & & Mandible & 3 & & & 1 & & \\
\hline & & Cervical vertebrae & 3 & & & 3 & & \\
\hline & & Thoracic vertebrae & 2 & & & 1 & & \\
\hline & & Lumbar vertebrae & 8 & & & 2 & & \\
\hline & & Ribs & 5 & & & 2 & & \\
\hline & & Scapula & 5 & 1 & & & & \\
\hline & & Radius & 2 & & & 1 & & \\
\hline & & Metacarpals or Metatarsals & 2 & & & 1 & & \\
\hline & & Pelvis & 2 & & 1 & & & \\
\hline & & Femur & 10 & 1 & & & & \\
\hline & & Tibia & 9 & 1 & & & & \\
\hline
\end{tabular}


TABLE 8.7 Animal remains discovered in T.8 (cont.)

\begin{tabular}{|c|c|c|c|c|c|c|c|c|}
\hline \multirow[t]{2}{*}{ Species } & \multirow[t]{2}{*}{ Context } & \multirow[t]{2}{*}{ Bone } & \multirow{2}{*}{$\begin{array}{l}\text { Number of } \\
\text { fragments }\end{array}$} & \multicolumn{3}{|c|}{ Number of bones } & \multirow{2}{*}{$\begin{array}{l}\text { Marks left } \\
\text { by termites }\end{array}$} & \multirow[t]{2}{*}{ Description } \\
\hline & & & & Right & Left & Right/left & & \\
\hline \multirow{6}{*}{ Ovicaprine } & \multirow{6}{*}{ Robber pit } & Lumbar vertebrae & 1 & & & 1 & & \multirow{6}{*}{ adult individual } \\
\hline & & Scapula & 2 & & & 1 (part) & & \\
\hline & & Radius & 5 & & 1 & & & \\
\hline & & Metacarpals or Metatarsals & 6 & & & 1 (part) & & \\
\hline & & Pelvis & 1 & & 1 & & & \\
\hline & & Femur & 2 & & 1 & & & \\
\hline \multirow{2}{*}{ Bird } & Tunnel & Long bones & 1 & & & 1 & & \multirow{2}{*}{$\begin{array}{l}\text { adult individual or } \\
\text { individuals, pigeon } \\
\text { size }\end{array}$} \\
\hline & Robber pit & Long bones & 1 & & & & & \\
\hline
\end{tabular}

PRODUCED BY U. IWASZCZUK

TABLE 8.8 Animal remains discovered in T.9

\begin{tabular}{|c|c|c|c|c|c|c|c|c|}
\hline \multirow[t]{2}{*}{ Species } & \multirow[t]{2}{*}{ Context } & \multirow[t]{2}{*}{ Bone } & \multirow{2}{*}{$\begin{array}{l}\text { Number of } \\
\text { fragments }\end{array}$} & \multicolumn{3}{|c|}{ Number of bones } & \multirow{2}{*}{$\begin{array}{l}\text { Marks left } \\
\text { by termites }\end{array}$} & \multirow[t]{2}{*}{ Description } \\
\hline & & & & Right & Left & Right/left & & \\
\hline \multirow{6}{*}{ Ovicaprine } & \multirow{4}{*}{$\begin{array}{l}\text { Chamber 1, southern and central part } \\
\text { (among human bones) }\end{array}$} & Rib & 7 & 1 & 1 & & & \multirow{4}{*}{$\begin{array}{l}1 \text { individual, relatively } \\
\text { young }\end{array}$} \\
\hline & & Humerus & 1 & & & 1 & & \\
\hline & & Pelvis & 2 & 1 & & & & \\
\hline & & Femur & 5 & & 1 & & & \\
\hline & \multirow{2}{*}{ Robber pit, south-eastern part } & Mandible & 13 & & & 1 & & \multirow{2}{*}{1 individual } \\
\hline & & Tooth & 8 & & & 1 & & \\
\hline
\end{tabular}

PRODUCED BY U. IWASZCZUK

(a humerus) could be determined to species (sheep). The other bones of cattle ( 8 fragments from 6 bones) and ovicaprine ( 33 fragments from 16 bones) were found dispersed, mostly at the eastern side of the chamber, and they represented the same carcass parts as the bones mentioned above. The only ovicaprine remains determined to species belonged to sheep.

In chamber 2 animal remains were distributed in four clusters (see Chapter 3.3, Fig. 3.103, this volume). The first two groups comprised only cattle bones. Group 1 , located in the southern part of the chamber near bottle $\mathrm{Zn1} / 26$, consisted of an articulated femur and patella. Group 2, found in and around a cup that was slipped and burnished on both sides (Z11/19), also in the southern part of the chamber, was made up of fragments of pelvis broken into pieces. Two other groups, located in the central (group 3) and northern (group 4) parts of the chamber, were more numerous (especially group 4) and contained not only cattle bones but also ovicaprine remains. There were 4 bones in group 3, including a cattle humerus and 3 ovicaprine bones, among them a sheep calcaneus. Two incomplete skeletons of cattle and sheep made up group 4; however, the bones were partially mixed. Both of them lacked cranial elements and extremities. Bones of cattle and ovicaprine were also scattered in the space between the clusters; some of them could have belonged to the abovementioned skeletons, and the rest came from other individuals.

Additionally, a fragment of cattle mandible and rib, as well as fragments of 4 ovicaprine bones from the thorax and proximal part of a forelimb, were found in the eastern part of the shaft.

Some of the bones bore post-consumption marks, such as chopping and filleting. Filleting marks were observed on cattle bones (lumbar and thoracic vertebrae, ribs, scapula, pelvis) as well as ovicaprine bones (thoracic vertebra). Chopping marks were also recorded on both cattle (scapula, ulna, pelvis) and ovicaprine bones (thoracic vertebra and pelvis). A few bones also bore marks indicating dismembering. In T.11 there were 3 such bones belonging to 
TABLE 8.9 Animal remains discovered in T.11

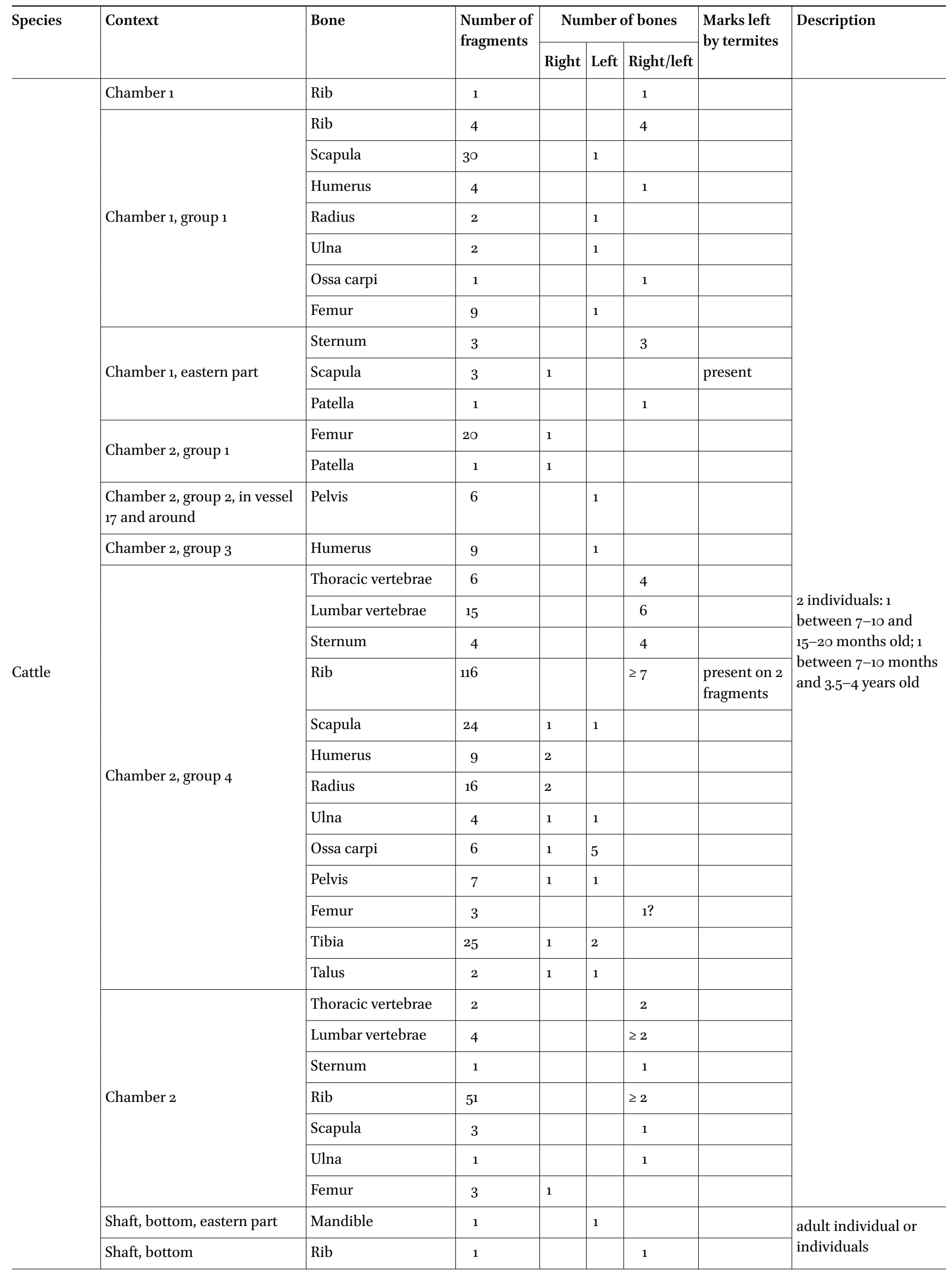


TABLE 8.9 Animal remains discovered in T.11 (cont.)

\begin{tabular}{|c|c|c|c|c|c|c|c|c|}
\hline \multirow[t]{2}{*}{ Species } & \multirow[t]{2}{*}{ Context } & \multirow[t]{2}{*}{ Bone } & \multirow{2}{*}{$\begin{array}{l}\text { Number of } \\
\text { fragments }\end{array}$} & \multicolumn{3}{|c|}{ Number of bones } & \multirow{2}{*}{$\begin{array}{l}\text { Marks left } \\
\text { by termites }\end{array}$} & \multirow[t]{2}{*}{ Description } \\
\hline & & & & Right & Left & Right/left & & \\
\hline \multirow{13}{*}{ Sheep } & \multirow{2}{*}{ Chamber 1} & Radius & 1 & & 1 & & & \multirow{13}{*}{$\begin{array}{l}2 \text { individuals: } 1 \text { under } \\
3-4 \text { months old; } 1 \\
\text { adult }\end{array}$} \\
\hline & & Calcaneus & 1 & & 1 & & & \\
\hline & \multirow{3}{*}{ Chamber 1 , eastern part } & Scapula & 4 & 1 & & & & \\
\hline & & Radius & 1 & 1 & & & & \\
\hline & & Femur & 8 & 1 & & & & \\
\hline & Chamber 1 , group 1 & Humerus & 2 & & 1 & & & \\
\hline & Chamber 2, group 3 & Calcaneus & 1 & 1 & & & & \\
\hline & \multirow{3}{*}{ Chamber 2, group 4} & Humerus & 2 & 2 & & & & \\
\hline & & Radius & 2 & 1 & 1 & & & \\
\hline & & Pelvis & 1 & 1 & & & & \\
\hline & Chamber 2 , in vessel 14 & Pelvis & 5 & 1 & & & & \\
\hline & \multirow{2}{*}{ Chamber 2} & Talus & 1 & 1 & & & & \\
\hline & & Tibia & 1 & 1 & & & & \\
\hline \multirow{25}{*}{ Ovicaprine } & Chamber 1 & Femur & 1 & & & 1 & & \multirow{25}{*}{$\begin{array}{l}2 \text { individuals: } 1 \\
\text { between } 5 \text { months and } \\
3.5 \text { years old; } 1 \text { under } \\
\text { 15-20 months, prob- } \\
\text { ably remains from the } \\
\text { young sheep above }\end{array}$} \\
\hline & \multirow{10}{*}{ Chamber 1 , eastern part } & Cervical vertebrae & 2 & & & 1 & & \\
\hline & & Lumbar vertebrae & 2 & & & 1 & & \\
\hline & & Sternum & 1 & & & 1 & & \\
\hline & & Humerus & 1 & & & 1 & & \\
\hline & & Ulna & 1 & & & 1 & & \\
\hline & & Metacarpal & 2 & & & $2 ?$ & & \\
\hline & & Ossa carpi & 1 & & & 1 & & \\
\hline & & Femur & 5 & & & $1 ?$ & & \\
\hline & & Tibia & 1 & & 1 & & & \\
\hline & & Calcaneus & 1 & & & 1 & & \\
\hline & \multirow{4}{*}{ Chamber 1 , group 1} & Sternum & 1 & & & 1 & & \\
\hline & & Radius & 1 & & 1 & & & \\
\hline & & Femur & 8 & & 1 & & & \\
\hline & & Tibia & 2 & & 1 & & & \\
\hline & \multirow{2}{*}{ Chamber 2, group 3} & Rib & 2 & & & 1 & & \\
\hline & & Pelvis & 1 & & & 1 & & \\
\hline & \multirow{8}{*}{ Chamber 2, group 4} & Cervical vertebrae & 1 & & & 1 & & \\
\hline & & Thoracic vertebrae & 3 & & & 3 & & \\
\hline & & Lumbar vertebrae & 4 & & & 1 & & \\
\hline & & Rib & 26 & & & $1 ?$ & & \\
\hline & & Radius & 1 & & & 1 & & \\
\hline & & Ulna & 2 & 1 & & & & \\
\hline & & Ossa carpi & 2 & 2 & & & & \\
\hline & & Pelvis & 3 & 1 & 1 & & & \\
\hline
\end{tabular}


TABLE 8.9 Animal remains discovered in T.11 (cont.)

\begin{tabular}{|c|c|c|c|c|c|c|c|c|}
\hline \multirow[t]{2}{*}{ Species } & \multirow[t]{2}{*}{ Context } & \multirow[t]{2}{*}{ Bone } & \multirow{2}{*}{$\begin{array}{l}\text { Number of } \\
\text { fragments }\end{array}$} & \multicolumn{3}{|c|}{ Number of bones } & \multirow{2}{*}{$\begin{array}{l}\text { Marks left } \\
\text { by termites }\end{array}$} & \multirow[t]{2}{*}{ Description } \\
\hline & & & & Right & Left & Right/left & & \\
\hline \multirow{10}{*}{ Ovicaprine } & \multirow{2}{*}{ Chamber 2, group 4} & Tibia & 6 & & & $1 ?$ & & \\
\hline & & Ossa tarsi & 1 & 1 & & & & \\
\hline & \multirow{6}{*}{ Chamber 2} & Rib & 25 & & & 1 & & \\
\hline & & Humerus & 4 & & & 1 & & \\
\hline & & Radius & 1 & & & 1 & & \\
\hline & & Femur & 3 & & & $1 ?$ & & \\
\hline & & Tibia & 5 & 1 & & & & \\
\hline & & Ossa tarsi & 1 & & & 1 & & \\
\hline & \multirow{2}{*}{ Shaft, bottom } & Rib & 14 & & & $\geq 3$ & & \multirow{2}{*}{$\begin{array}{l}\text { adult individual or } \\
\text { individuals }\end{array}$} \\
\hline & & Humerus & 3 & & & 1 & & \\
\hline
\end{tabular}

PRODUCED BY U. IWASZCZUK

cattle: a pelvis with cut marks visible on the acetabulum, a mandible with cut marks between the processes, and a talus with a cut mark recorded on the distal end. There were also 2 ovicaprine bones with such marks: a humerus with a cut mark visible near the trochlea, and a sheep radius with a cut mark on the proximal end. Additionally, a cattle talus bore marks of skinning on the medial surface.

\subsubsection{Tumulus 12}

2,451 animal bones and bone fragments were found in two chambers and in the shaft; 925 of them remain unidentified. It seems that most of the remains from the shaft were originally deposited in chamber 1 . Some of them might have got there together with the shaft fill during the funeral or as a result of robber activity. The bones came from two cattle individuals and at least two sheep [Table 8.10]. The cattle remains belonged to two animals between $12-15$ months and $3 \cdot 5^{-4}$ years old, while the sheep bones came from one individual aged about 3.5 years and one individual between 5 and $15^{-20}$ months old. The bones found in the shaft belonged to young animals, probably from the carcasses deposited in the chambers. It was possible to establish sheep withers height on the basis of three bones from one animal. The results were between $65.8 \mathrm{~cm}$ and $73.3 \mathrm{~cm}$ with an average of $68.8 \mathrm{~cm}$. In chamber 2 one cattle rib and a few sheep bones (ribs and sternum, a fragment of the proximal part of the right and left forelimbs and two bones from the proximal part of a hind limb) were found. Many more bones were discovered in chamber 3 . There were at least five cuts of beef there: part of the thorax, the right and left forelimbs without extremities, and the right and left parts of the hind limbs, also without extremities. The sheep remains were represented by ribs, bones from the proximal part of the left forelimb, and a big part of the left hind limb without extremities. Additionally, four beef cuts were deposited in a large and shallow bowl, slipped on the inside (Z12/125): ribs, bones from the proximal part of the left forelimb and the distal part of the right forelimb, and probably the proximal part of a hind limb. Bones were also located in four clusters in the northern, southern, south-eastern, and western parts of the shaft (see Chapter 3.3, Fig. 3.44a, in this volume). They consisted of ribs and the proximal parts of the limbs of cattle, and of fragments from the thorax and limbs (mostly the proximal parts) of two young sheep individuals.

Some of the cattle and ovicaprine bones bore evidence of chopping, cutting (ribs, humerus, and radius) and filleting (vertebrae, ribs, and radius) [Fig. 8.9].

\subsubsection{Tumulus 13}

Animal remains were found in almost all of the structures of this grave. As the ceiling of chamber 1 collapsed and excavation was, therefore, impossible (see Chapter $3 \cdot 3$, Fig. 3.53, this volume), only those bones found among the bricks of the blocking wall that fell into the shaft were analysed. These bones were mixed with human remains and other artefacts, such as faience beads, arrowheads, and pottery, and they had probably been thrown out of the chamber during looting. The total number of animal remains was 558 fragments, only 96 of which could not be identified. Bone fragments came from three young individuals of cattle: two of them were about $7-10$ months 

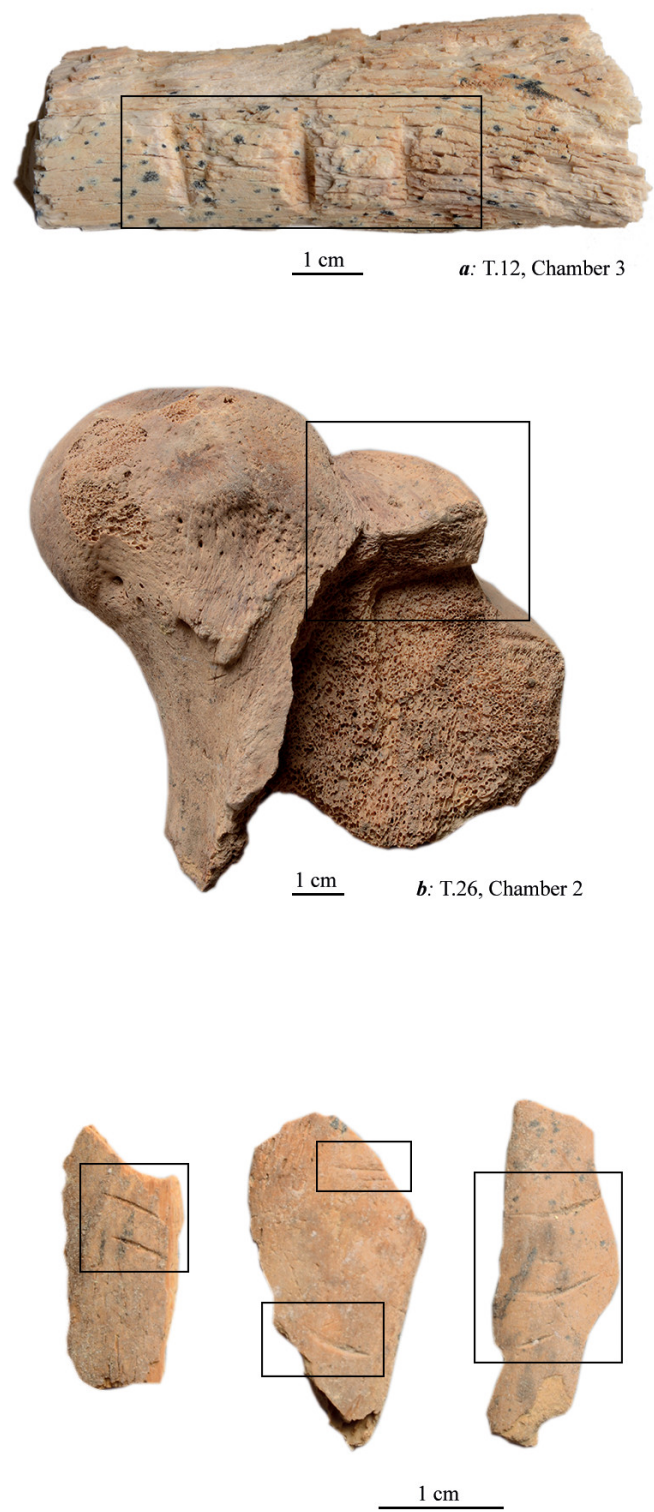
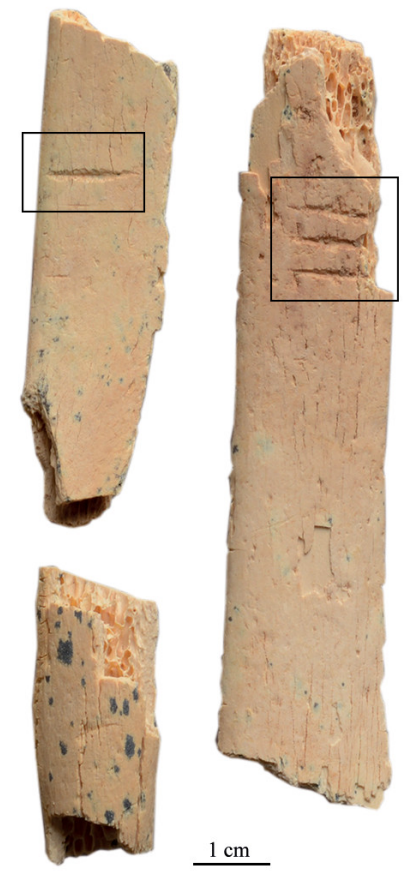

c: T.12, shaft

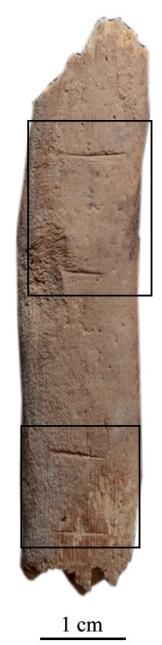

d: T.7, context 5
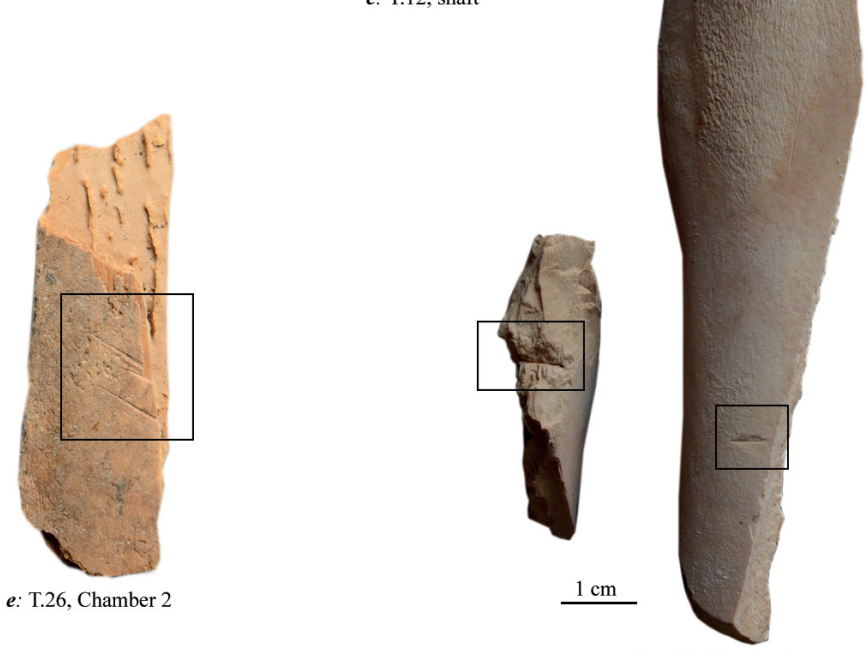

f: T.13, Chamber 3

FIGURE 8.9 Cutting and chopping marks visible on cattle bones from El-Zuma: a-chopping marks on a humerus (this bone is also weathered); $\mathrm{b}$ - chopping marks on a femur; c - filleting marks on a rib; $\mathrm{d}-\mathrm{e}-$ filleting marks on ribs; $\mathrm{f}-$ chopping and cut marks on a humerus PHOTOS BY A. KAMROWSKI

old (only 2 bone fragments of the second animal were found in the grave) and one was about $15^{-20}$ months old. Ovicaprine remains were less numerous and the majority of them belonged to 1 sheep aged about 5 months. A further 2 fragments of ribs found in chamber 3 in a bowl with grooved decoration, slipped and polished on both surfaces (Z13/27), came from an adult animal. In the extension of the robber pit, on its northern side, there was also a fragment of goat skull and 1 bivalve shell broken into pieces. It is highly improbable that they were connected with funerary rituals [Table 8.11].
The remains from the shaft, which consisted exclusively of cattle and ovicaprine bones, were characteristic of almost all other chambers in tumuli of type II. Cattle was represented by 90 fragments from 11 bones of the thorax and proximal parts of the limbs. Ovicaprine remains were represented by 71 fragments from 9 bones, among them 7 fragments from 3 sheep bones, all of which came from the same body parts as the cattle remains. The content of additional chambers was very similar: only cattle and ovicaprine bones from the same parts of the carcass were recorded in chambers 2, 3 and 5. Additionally, 
TABLE 8.10 Animal remains discovered in T.12

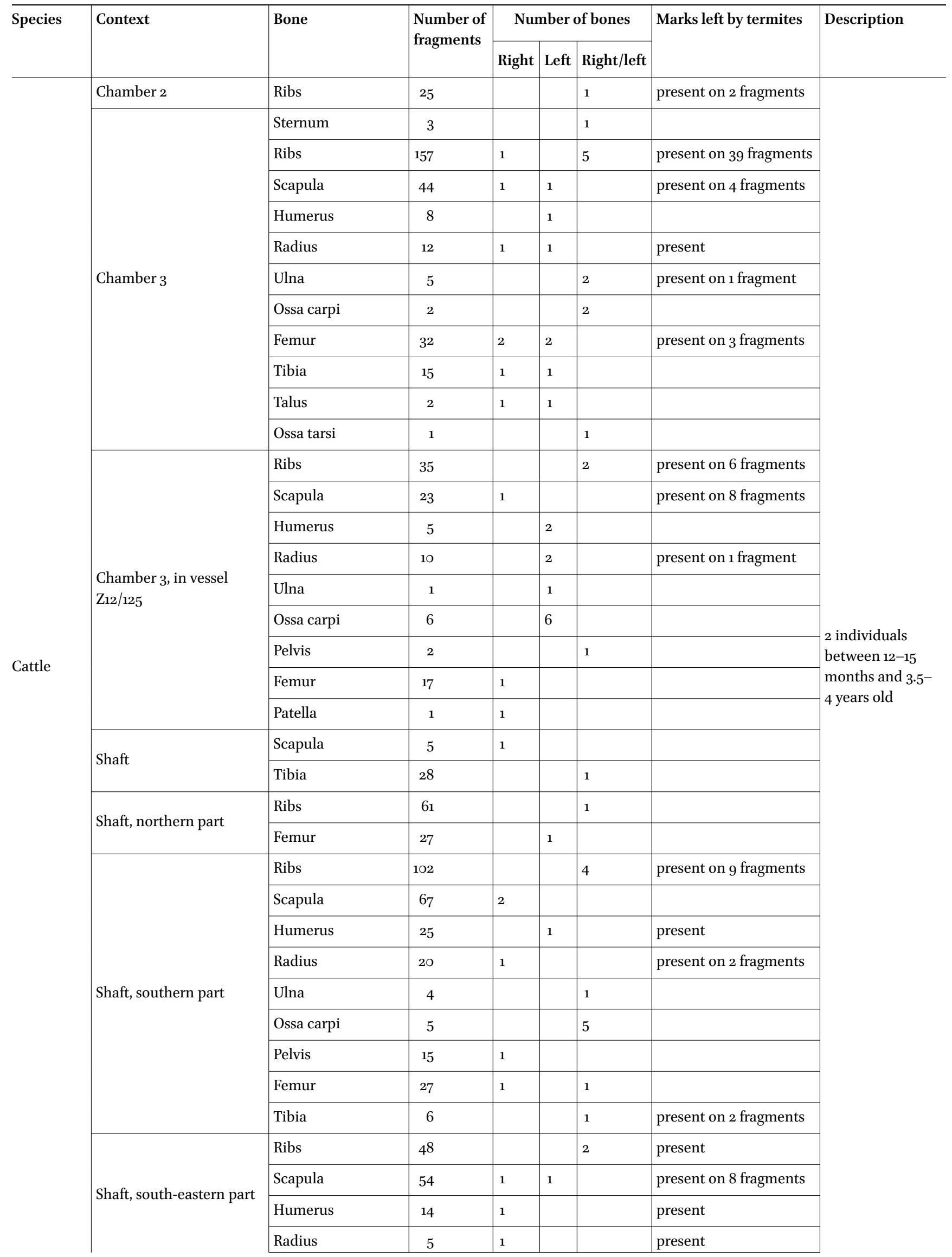


TABLE 8.10 Animal remains discovered in T.12 (cont.)

\begin{tabular}{|c|c|c|c|c|c|c|c|c|}
\hline \multirow[t]{2}{*}{ Species } & \multirow[t]{2}{*}{ Context } & \multirow[t]{2}{*}{ Bone } & \multirow{2}{*}{$\begin{array}{l}\text { Number of } \\
\text { fragments }\end{array}$} & \multicolumn{3}{|c|}{ Number of bones } & \multirow[t]{2}{*}{ Marks left by termites } & \multirow[t]{2}{*}{ Description } \\
\hline & & & & Right & Left & Right/left & & \\
\hline \multirow{5}{*}{ Cattle } & \multirow{4}{*}{ Shaft, south-eastern part } & Ulna & 2 & & & 1 & & \\
\hline & & Ossa carpi & 4 & & & 4 & & \\
\hline & & Pelvis & 8 & & 1 & & & \\
\hline & & Femur & 16 & 1 & 1 & & present on 1 fragment & \\
\hline & Shaft, western part & Ribs & 40 & & & 1 & & \\
\hline \multirow{33}{*}{ Sheep } & \multirow{9}{*}{ Chamber 2} & Sternum & 5 & & & 5 & & \multirow{18}{*}{$\begin{array}{l}2 \text { individuals: } 1 \\
\text { about } 3 \cdot 5 \text { years } \\
\text { old, } 1 \text { between } 5 \\
\text { and } 15^{-20} \text { months } \\
\text { old }\end{array}$} \\
\hline & & Ribs & $5^{8}$ & & & 2 & present on 6 fragments & \\
\hline & & Scapula & 10 & & 1 & & & \\
\hline & & Humerus & 11 & & 1 & & present & \\
\hline & & Radius & 2 & 1 & & & present & \\
\hline & & Ulna & 2 & 1 & & & & \\
\hline & & Ossa carpi & 3 & & & 3 & & \\
\hline & & Pelvis & 5 & & 1 & & & \\
\hline & & Femur & 5 & 1 & & & present & \\
\hline & \multirow{9}{*}{ Chamber 3} & Ribs & 39 & 1 & & 2 & present on 2 fragments & \\
\hline & & Scapula & 10 & & 1 & & & \\
\hline & & Humerus & 3 & & 1 & & & \\
\hline & & Pelvis & 7 & & 1 & & & \\
\hline & & Femur & 2 & 1 & & & & \\
\hline & & Patella & 1 & & & 1 & & \\
\hline & & Tibia & 7 & 1 & 1 & & & \\
\hline & & Calcaneus & 2 & 1 & 1 & & & \\
\hline & & Talus & 1 & 1 & & & & \\
\hline & \multirow{12}{*}{ Shaft, southern part } & Atlas & 2 & & & 1 & & \multirow{12}{*}{ young individual } \\
\hline & & Axis & 1 & & & 1 & & \\
\hline & & Cervical vertebrae & 24 & & & 5 & & \\
\hline & & Thoracic vertebrae & 39 & & & 8 & & \\
\hline & & Lumbar vertebrae & 42 & & & 6 & & \\
\hline & & Sacrum & 4 & & & 1 & & \\
\hline & & Ribs & 32 & & & 3 & & \\
\hline & & Scapula & 48 & 1 & & & & \\
\hline & & Humerus & 7 & 1 & & & & \\
\hline & & Radius & 3 & & 1 & & & \\
\hline & & Ulna & 6 & & 1 & & & \\
\hline & & Ossa carpi & 3 & & & 3 & & \\
\hline & \multirow{3}{*}{ Shaft, south-eastern part } & Atlas & 1 & & & 1 & & \multirow{3}{*}{ young individual } \\
\hline & & Axis & 1 & & & 1 & & \\
\hline & & Cervical vertebrae & 15 & & & 5 & & \\
\hline
\end{tabular}


TABLE 8.10 Animal remains discovered in T.12 (cont.)

\begin{tabular}{|c|c|c|c|c|c|c|c|c|}
\hline \multirow[t]{2}{*}{ Species } & \multirow[t]{2}{*}{ Context } & \multirow[t]{2}{*}{ Bone } & \multirow{2}{*}{$\begin{array}{l}\text { Number of } \\
\text { fragments }\end{array}$} & \multicolumn{3}{|c|}{ Number of bones } & \multirow[t]{2}{*}{ Marks left by termites } & \multirow[t]{2}{*}{ Description } \\
\hline & & & & Right & Left & Right/left & & \\
\hline \multirow{9}{*}{ Sheep } & \multirow{9}{*}{ Shaft, south-eastern part } & Thoracic vertebrae & 22 & & & 6 & & \\
\hline & & Lumbar vertebrae & 29 & & & 6 & & \\
\hline & & Sacrum & 3 & & & 1 & & \\
\hline & & Ribs & 21 & & & 2 & & \\
\hline & & Scapula & 7 & & 1 & & & \\
\hline & & Humerus & 3 & & 1 & & & \\
\hline & & Radius & 3 & & 1 & & present & \\
\hline & & Ulna & 5 & & 1 & & & \\
\hline & & Ossa carpi & 3 & & & 3 & & \\
\hline \multirow{3}{*}{ Ovicaprine } & \multirow{3}{*}{ Shaft, western part } & Lumbar vertebrae & 17 & & & 4 & & \multirow{3}{*}{$\begin{array}{l}\text { young individual } \\
\text { or individuals }\end{array}$} \\
\hline & & Ribs & 2 & & & 1 & & \\
\hline & & Femur & 11 & & & 1 & & \\
\hline
\end{tabular}

PRODUCED BY U. IWASZCZUK
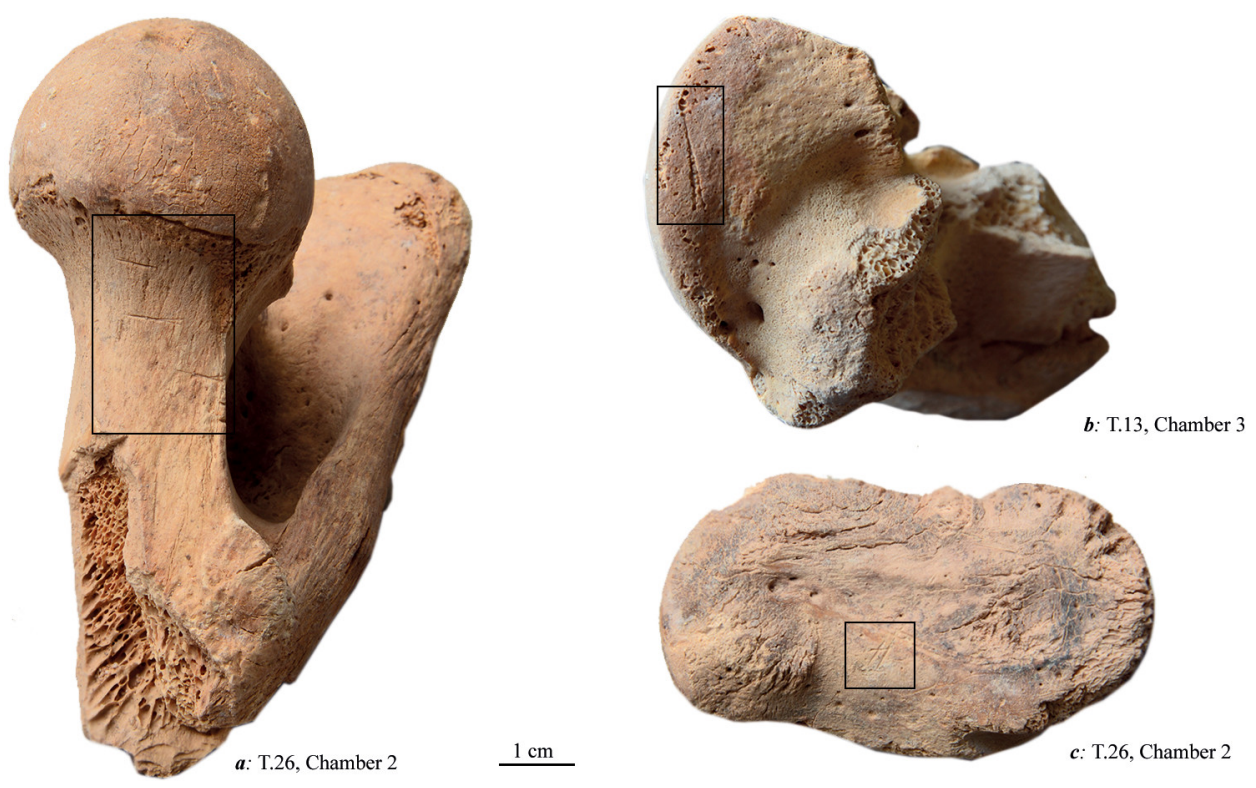

FIGURE 8.10 Dismemberment marks visible on cattle bones from El-Zuma: a-femur; b-humerus; c-talus

PHOTOS BY A. KAMROWSKI

one ovicaprine rib was found in bowl $\mathrm{Z}_{13} / 27$. There were also fragments of 2 ovicaprine ribs in a bowl slipped and burnished on both sides $\left(\mathrm{Z}_{13} / 11\right)$, located in the western part of chamber 5 .

Some of the cattle and ovicaprine bones bore postconsumption marks as well as marks made during dismembering. The bones showed traces of cutting (a rib, scapula, pelvis, and 2 femurs) and filleting (3 ribs, a scapula, pelvis, and femur). Evidence of dismembering was vis- ible on 2 bones: a pelvis with a cut mark on the sacral tuber, and a humerus with 2 parallel cut marks on the trochlea and a cut mark on the shaft near the distal end [Figs. 8.9, 8.10, 8.11]. 
TABLE 8.11 Animal remains discovered in T.13

\begin{tabular}{|c|c|c|c|c|c|c|c|c|}
\hline \multirow[t]{2}{*}{ Species } & \multirow[t]{2}{*}{ Context } & \multirow[t]{2}{*}{ Bone } & \multirow{2}{*}{$\begin{array}{l}\text { Number of } \\
\text { fragments }\end{array}$} & \multicolumn{3}{|c|}{ Number of bones } & \multirow[t]{2}{*}{ Marks left by termites } & \multirow[t]{2}{*}{ Description } \\
\hline & & & & Right & Left & Right/left & & \\
\hline \multirow{19}{*}{ Cattle } & \multirow{10}{*}{ Shaft, among human bones } & Lumbar vertebrae & 1 & & & 1 & & \multirow{19}{*}{$\begin{array}{l}3 \text { individuals: } \\
1 \text { about } 7-10 \\
\text { months old, } 1 \\
\text { about } 15^{-20} \\
\text { months old, } \\
1 \text { about } 7-10 \\
\text { months (only } \\
2 \text { bones) }\end{array}$} \\
\hline & & Rib & 41 & & & $\geq 2$ & present on 4 fragments & \\
\hline & & Scapula & 1 & & 1 & & & \\
\hline & & Humerus & 3 & & 1 & & present & \\
\hline & & Ossa carpi & 1 & & 1 & & & \\
\hline & & Pelvis & 12 & 1 & & & & \\
\hline & & Femur & 19 & 1 & & & present & \\
\hline & & Patella & 1 & 1 & & & & \\
\hline & & Tibia & 10 & 1 & & & & \\
\hline & & Talus & 1 & 1 & & & & \\
\hline & \multirow{3}{*}{ Chamber 2} & Rib & 15 & & & 1 & present on 4 fragments & \\
\hline & & Pelvis & 17 & 2 & & & & \\
\hline & & Femur & 6 & 1 & & & & \\
\hline & \multirow{4}{*}{ Chamber 3} & Thoracic vertebrae & 3 & & & 1 & & \\
\hline & & Rib & 30 & & $\geq 4$ & & & \\
\hline & & Scapula & 116 & 2 & 1 & & & \\
\hline & & Humerus & 24 & & 1 & & & \\
\hline & \multirow{2}{*}{ Chamber 5 , group 1} & Rib & 5 & & & 2 & & \\
\hline & & Pelvis & 3 & & 1 & & & \\
\hline \multirow{10}{*}{ Sheep } & \multirow{3}{*}{ Shaft, among human bones } & Tibia & 5 & 1 & & & & \multirow{10}{*}{$\begin{array}{l}1 \text { individual } \\
\text { about } 5 \\
\text { months old }\end{array}$} \\
\hline & & Calcaneus & 1 & 1 & & & & \\
\hline & & Talus & 1 & 1 & & & & \\
\hline & \multirow{7}{*}{ Chamber 3} & Pelvis & 2 & & 1 & & & \\
\hline & & Femur & 13 & & 1 & & & \\
\hline & & Patella & 1 & & 1 & & & \\
\hline & & Tibia & 3 & & 1 & & & \\
\hline & & Calcaneus & 1 & & 1 & & & \\
\hline & & Talus & 1 & & 1 & & & \\
\hline & & Sesamoid & 1 & & & 1 & & \\
\hline Goat & $\begin{array}{l}\text { Extension of the robber pit on } \\
\text { the northern side }\end{array}$ & Skull & 1 & & & 1 & & 1 individual \\
\hline \multirow{7}{*}{ Ovicaprine } & \multirow{6}{*}{ Shaft, among human bones } & Rib & 44 & & & $1 ?$ & present & \multirow{7}{*}{$\begin{array}{l}\text { most of the } \\
\text { bones from } \\
\text { the above } \\
\text { sheep; addi- } \\
\text { tionally, } 2 \\
\text { fragments of } \\
\text { rib from an } \\
\text { adult indi- } \\
\text { vidual }\end{array}$} \\
\hline & & Humerus & 1 & & & 1 & & \\
\hline & & Femur & 16 & 1 & & & present & \\
\hline & & Patella & 1 & 1 & & & & \\
\hline & & Metatarsal & 1 & & & 1 & & \\
\hline & & Sesamoid & 1 & & & 1 & & \\
\hline & Chamber 2 & Rib & 13 & & & 1 & present & \\
\hline
\end{tabular}


TABLE 8.11 Animal remains discovered in T.13 (cont.)

\begin{tabular}{|c|c|c|c|c|c|c|c|c|}
\hline \multirow[t]{2}{*}{ Species } & \multirow[t]{2}{*}{ Context } & \multirow[t]{2}{*}{ Bone } & \multirow{2}{*}{$\begin{array}{l}\text { Number of } \\
\text { fragments }\end{array}$} & \multicolumn{3}{|c|}{ Number of bones } & \multirow[t]{2}{*}{ Marks left by termites } & \multirow[t]{2}{*}{ Description } \\
\hline & & & & Right & Left & Right/left & & \\
\hline \multirow{3}{*}{ Ovicaprine } & Chamber 3 & Rib & 30 & 7 & 5 & & & \multirow{3}{*}{ See above } \\
\hline & $\begin{array}{l}\text { Chamber } 5 \text {, group 2, in vessel } \\
\mathrm{Z}_{13} / 11\end{array}$ & Rib & 10 & & 1 & 1 & & \\
\hline & Chamber 3 , in vessel $Z_{13} / 27$ & Rib & 1 & & & 1 & & \\
\hline
\end{tabular}

PRODUCED BY U. IWASZCZUK

\subsubsection{Tumulus 14}

The 538 animal bone fragments from this tumulus and the context of their discovery have already been described (Iwaszczuk, Niderla-Bielińska, and Ścieżyńska 2019, 2223). They were found exclusively in the burial chambers and two additional chambers [Table 8.12]. The content of this grave was very typical of type II tumuli and similar to that of all other graves of this type but one (T.9) at the ElZuma cemetery.

\subsubsection{Tumulus 15}

The animal remains from this tumulus have been partially discussed before (Iwaszczuk 2015); however, after publishing the material some new remains from this grave were analysed, which is why it was important to revise the earlier results. T.15 was the best equipped type II tumulus, though the state of preservation of the faunal material was very poor and resulted in a great number of unidentified small bone fragments: 925 elements out of 1,921 remain undetermined.

Chamber 1 contained pottery and a few fragments of nails and bed frame fittings together with human and animal remains. Pottery (in two clusters) (see Chapter 3.3, Fig. 3.65a, this volume) and animal bones (in one cluster in the central part of the chamber) were also discovered in chamber 2, though mostly animal remains and some botanical remains were excavated in this part of the grave.

Cattle remains (779 fragments from 35 bones) were deposited in the burial chamber (Ch. 1) and in one of the additional chambers (Ch. 2) [Table 8.13]. Some of the cattle bones were also found in the shaft, in the vicinity of chamber 1 , and might have originally come from the burial chamber. It is interesting that 5 cattle ribs together with 3 ovicaprine ribs were found in a bowl in the northern part of chamber 2. The remains located in the chambers and shaft came from the thorax (cervical vertebrae and ribs) and proximal parts of forelimbs (scapula and humerus) and hind limbs (pelvis, femur, patella, and tibia) with the addition of one left and two right taluses. Cattle bones from this grave belonged to three individuals: one about
2-2.5 years old, one aged between $2-2.5$ and $3.5^{-4}$ years and the last one over $3.5-4$ years.

Ovicaprine bones were less frequent than cattle remains [see Table 8.13]. Only 26 fragments from 5 bones belonged to sheep, while another 191 fragments from 19 bones could not be identified to species. Sheep bones (a pelvis and femur) were deposited in situ in chambers 1 and 3 . Three other bones ( 3 humeri and 1 femur) were probably thrown out of chamber 1 and were found in the shaft near this chamber. The remains belonged to 2 individuals: one under 3.5 years old and one about 3-3.5 years old. Ovicaprine bones were also deposited in chambers 2 and 3 . In chamber 2 there were only three ribs inside a bowl slipped and burnished on both sides $\left(\mathrm{Z}_{15} / 35\right)$, while in chamber 3 the bones were found on the floor. The other bones were recovered from the shaft in the vicinity of chamber 1 . Altogether, 165 fragments from 16 bones were found in these contexts. They came from the thorax (ribs, lumbar vertebra, and sacrum) and proximal parts of the forelimb (humerus) and hind limb (femur and tibia) and probably belonged to the 2 sheep mentioned above. There were also 26 fragments from 3 bones (mandible, rib, and femur) discovered in the fill of the shaft that came from a different individual or individuals.

It seems that the animal offerings deposited in T.14 and T.15 were typical of this type of grave. Similar animal remains that came only from cattle and ovicaprines (most probably sheep only, as the goat remains were not found in sepulchral contexts) are known from other type II tumuli in El-Zuma, such as T.11, T.12, T.13, T.16, T.24, and T.26. Only T.9 had a different bone assemblage, yielding only a few ovicaprine bones during excavation; however, this grave had been damaged by the collapse of the chambers' ceilings, and the fill of the chambers was very wet, which might have caused the destruction of the botanical and zoological remains. 
TABLE 8.12 Animal remains discovered in T.14

\begin{tabular}{|c|c|c|c|c|c|c|c|c|}
\hline \multirow[t]{2}{*}{ Species } & \multirow[t]{2}{*}{ Context } & \multirow[t]{2}{*}{ Bone } & \multirow{2}{*}{$\begin{array}{l}\text { Number of } \\
\text { fragments }\end{array}$} & \multicolumn{3}{|c|}{ Number of bones } & \multirow[t]{2}{*}{ Marks left by termites } & \multirow[t]{2}{*}{ Description } \\
\hline & & & & Right & Left & Right/left & & \\
\hline \multirow{16}{*}{ Cattle } & \multirow{7}{*}{ Chamber 1} & Cervical vertebrae & 1 & & & 1 & & \multirow{16}{*}{$\begin{array}{l}2 \text { individuals: } 1 \text { between } 2- \\
2.5 \text { and } 3 \cdot 5^{-4} \text { years old, } 1 \\
\text { between } 3 \cdot 5^{-4} \text { and } 5 \text { years } \\
\text { old }\end{array}$} \\
\hline & & Thoracic vertebrae & 1 & & & 1 & & \\
\hline & & Sternum & 1 & & & 1 & & \\
\hline & & Rib & 43 & 1 & 1 & 1 & present on 1 fragment & \\
\hline & & Scapula & 1 & 1 & & & & \\
\hline & & Femur & 16 & & 1 & & & \\
\hline & & Patella & 1 & & & 1 & & \\
\hline & \multirow{9}{*}{ Chamber 3} & Rib & 20 & & & $\geq 4$ & present on 3 fragments & \\
\hline & & Humerus & 6 & 1 & & & & \\
\hline & & Sternum & 6 & & & 3 & & \\
\hline & & Rib & 94 & 1 & & $\geq 6$ & present on 2 fragments & \\
\hline & & Scapula & 78 & & 1 & & & \\
\hline & & Humerus & 6 & 1 & & & & \\
\hline & & Tibia & 2 & 1 & & & & \\
\hline & & Talus & 1 & 1 & & & & \\
\hline & & Ossa tarsi & 1 & & & 1 & & \\
\hline \multirow{6}{*}{ Sheep } & \multirow{6}{*}{ Chamber 2} & Humerus & 5 & & 1 & & & \multirow{6}{*}{$\begin{array}{l}2 \text { individuals: } 1 \text { under } 3.5 \\
\text { years old, } 1 \text { about } 3.5 \text { years } \\
\text { old }\end{array}$} \\
\hline & & Radius & 1 & & 1 & & & \\
\hline & & Ulna & 3 & & 1 & & & \\
\hline & & Tibia & 17 & 1 & 1 & & & \\
\hline & & Calcaneus & 3 & & 2 & & & \\
\hline & & Talus & 2 & 1 & 1 & & & \\
\hline \multirow{13}{*}{ Ovicaprine } & \multirow{2}{*}{ Chamber 1} & Humerus & 1 & & & 1 & present & \multirow{13}{*}{$\begin{array}{l}\text { probably from } 2 \text { of the } \\
\text { above sheep }\end{array}$} \\
\hline & & Tibia & 2 & & & 1 & & \\
\hline & \multirow{6}{*}{ Chamber 2} & Rib & 13 & & & $\geq 2$ & & \\
\hline & & Scapula & 3 & & & 1 & & \\
\hline & & Ossa carpi & 1 & & & 1 & & \\
\hline & & Pelvis & 6 & 1 & & & & \\
\hline & & Ossa tarsi & 1 & & & 1 & & \\
\hline & & Centroquartale & 1 & 1 & & & & \\
\hline & \multirow{5}{*}{ Chamber 3} & Rib & 110 & 1 & 1 & $\geq 6$ & & \\
\hline & & Sternum & 11 & & & $\geq 2$ & & \\
\hline & & Pelvis & 5 & 1 & & & & \\
\hline & & Femur & 6 & 1 & 1 & & & \\
\hline & & Patella & 1 & & & 1 & & \\
\hline
\end{tabular}

PRODUCED BY U. IWASZCZUK 
TABLE 8.13 Animal remains discovered in T.15

\begin{tabular}{|c|c|c|c|c|c|c|c|c|}
\hline \multirow[t]{2}{*}{ Species } & \multirow[t]{2}{*}{ Context } & \multirow[t]{2}{*}{ Bone } & \multirow{2}{*}{$\begin{array}{l}\text { Number of } \\
\text { fragments }\end{array}$} & \multicolumn{3}{|c|}{ Number of bones } & \multirow[t]{2}{*}{ Marks left by termites } & \multirow[t]{2}{*}{ Description } \\
\hline & & & & Right & Left & Right/left & & \\
\hline \multirow{13}{*}{ Cattle } & \multirow{3}{*}{ Chamber 1} & Rib & 37 & & 1 & 2 & & \multirow{13}{*}{$\begin{array}{l}3 \text { individuals: } 1 \\
\text { about } 2-2.5 \text { years } \\
\text { old, } 1 \text { between } \\
2-2.5 \text { and } 3 \cdot 5^{-4} \\
\text { years old, } 1 \text { more } \\
\text { than } 3 \cdot 5^{-4} \text { years } \\
\text { old }\end{array}$} \\
\hline & & Tibia & 8 & 1 & & 1 & & \\
\hline & & Talus & 1 & & & 1 & & \\
\hline & \multirow{2}{*}{ Chamber 2} & Scapula & 181 & & 1 & & & \\
\hline & & Humerus & 53 & 1 & & & present & \\
\hline & Chamber 2 , in vessel $\mathrm{Z}_{15} / 39$ & Rib & 138 & 2 & & 3 & present on 23 fragments & \\
\hline & \multirow{7}{*}{$\begin{array}{l}\text { Shaft (in the vicinity of } \\
\text { chamber 1) }\end{array}$} & Rib & 218 & & & 6 & present on 15 fragments & \\
\hline & & Cervical vertebrae & 1 & & & 1 & & \\
\hline & & Pelvis & 25 & & 1 & 1 & & \\
\hline & & Femur & 70 & 3 & 2 & & & \\
\hline & & Patella & 1 & 1 & & & & \\
\hline & & Tibia & 43 & 2 & 2 & & & \\
\hline & & Talus & 3 & 2 & 1 & & & \\
\hline \multirow{4}{*}{ Sheep } & Chamber 1 & Femur & 13 & 1 & & & & \multirow{4}{*}{$\begin{array}{l}2 \text { individuals: } 1 \\
\text { under } 3.5 \text { years } \\
\text { old, } 1 \text { about } 3-3.5 \\
\text { years old }\end{array}$} \\
\hline & Chamber 3 & Pelvis & 9 & 1 & & & & \\
\hline & \multirow{2}{*}{$\begin{array}{l}\text { Shaft (in the vicinity of } \\
\text { chamber } 1 \text { ) }\end{array}$} & Humerus & 3 & 1 & & 1 & & \\
\hline & & Femur & 1 & & & 1 & & \\
\hline \multirow{11}{*}{ Sheep/goat } & Chamber 2 , in vessel $Z_{15} / 39$ & Rib & 14 & 2 & & 1 & & \multirow{8}{*}{$\begin{array}{l}\text { probably from } \\
2 \text { of the above } \\
\text { sheep }\end{array}$} \\
\hline & \multirow{3}{*}{ Chamber 3} & Lumbar vertebrae & 9 & & & $\geq 2$ & & \\
\hline & & Sacrum & 1 & & & 1 & & \\
\hline & & Rib & 23 & & & $\geq 3$ & & \\
\hline & \multirow{4}{*}{$\begin{array}{l}\text { Shaft (in the vicinity of } \\
\text { chamber } 1 \text { ) }\end{array}$} & Rib & 75 & & & 2 & & \\
\hline & & Humerus & 3 & & & 1 & & \\
\hline & & Femur & 24 & 1 & 1 & & & \\
\hline & & Tibia & 16 & & 1 & 1 & & \\
\hline & \multirow{3}{*}{ Shaft } & Mandible & 15 & & & 1 & & \multirow{3}{*}{$\begin{array}{l}\text { probably not } \\
\text { from the } 2 \text { sheep } \\
\text { above }\end{array}$} \\
\hline & & Rib & 5 & & & 1 & & \\
\hline & & Femur & 6 & & & 1 & & \\
\hline
\end{tabular}

PRODUCED BY U. IWASZCZUK

\subsubsection{Tumulus 16}

Animal remains were discovered in 2 clusters: in the northern part of chamber 1 (group 1) and in the southern part of this chamber, in the vicinity of the blocking wall (group 2) (see Chapter 3.3, Fig. 3.93, in this volume). Additionally, 2 bones were mixed with the human remains in the southern part of the chamber, and other bones were discovered in the central and southern part of chamber 2, as well as in the shaft and robber pit. One cattle and 2 ovicaprine bones were also found during the excavation of the superstructure, but it seems that they were not connected with funerary rituals and got there accidentally. There were 605 bone and tooth fragments in total, among them 174 fragments that could not be identified to species. There were only cattle and ovicaprine remains present in these assemblages. The cattle bones came from 2 individuals: the first one was about 3.5-4 years old and the other was an adult (but only the tibia of this animal was found in chamber 2) [Table 8.14]. 
TABLE 8.14 Animal remains discovered in T.16

\begin{tabular}{|c|c|c|c|c|c|c|c|c|}
\hline \multirow[t]{2}{*}{ Species } & \multirow[t]{2}{*}{ Context } & \multirow[t]{2}{*}{ Bone } & \multirow{2}{*}{$\begin{array}{l}\text { Number of } \\
\text { fragments }\end{array}$} & \multicolumn{3}{|c|}{ Number of bones } & \multirow{2}{*}{$\begin{array}{l}\text { Marks left } \\
\text { by termites }\end{array}$} & \multirow[t]{2}{*}{ Description } \\
\hline & & & & Right & Left & Right/left & & \\
\hline \multirow{24}{*}{ Cattle } & Chamber 1 (among human bones) & Rib & 1 & & & 1 & & \multirow{20}{*}{$\begin{array}{l}2 \text { individuals: } 1 \\
\text { about } 3 \cdot 5^{-4} \text { years } \\
\text { old, } 1 \text { adult (tibia } \\
\text { only) }\end{array}$} \\
\hline & \multirow{4}{*}{$\begin{array}{l}\text { Chamber 1, northern part, group no. 1, } \\
\text { near beer jar }\end{array}$} & Sternum & 1 & & & 1 & & \\
\hline & & Rib & 22 & & & 1 & present & \\
\hline & & Pelvis & 14 & & 1 & & & \\
\hline & & Femur & 16 & & 1 & & & \\
\hline & \multirow{2}{*}{$\begin{array}{l}\text { Chamber 1, southern part, group no. } 2 \text {, } \\
\text { near beer jar }\end{array}$} & Rib & 10 & 1 & & & & \\
\hline & & Humerus & 15 & & 1 & & & \\
\hline & \multirow{11}{*}{ Chamber 2, central and southern part } & Lumbar vertebrae & 5 & & & 1 & & \\
\hline & & Sacrum & 4 & & & 1 & & \\
\hline & & Sternum & 7 & & & 7 & & \\
\hline & & Rib & 173 & 2 & 6 & 1 & $\begin{array}{l}\text { present on } 6 \\
\text { fragments }\end{array}$ & \\
\hline & & Scapula & 60 & 1 & & & & \\
\hline & & Humerus & 1 & 1 & & & & \\
\hline & & Pelvis & 13 & 1 & & & & \\
\hline & & Patella & 1 & 1 & & & & \\
\hline & & Tibia & 46 & 1 & 2 & & & \\
\hline & & Talus & 2 & 1 & 1 & & & \\
\hline & & Ossa tarsi & 3 & 2 & 1 & & & \\
\hline & $\begin{array}{l}\text { Shaft, from damaged blocking wall, } \\
\text { southern part }\end{array}$ & Rib & 12 & & & 1 & & \\
\hline & $\begin{array}{l}\text { Shaft, central part, near damaged block- } \\
\text { ing wall }\end{array}$ & Femur & 9 & 1 & & & & \\
\hline & Shaft, central part & Skull & 1 & & & 1 & & \multirow{4}{*}{$\begin{array}{l}\text { adult individual } \\
\text { or individuals }\end{array}$} \\
\hline & Shaft, south-eastern part & Tooth & 1 & & & 1 & & \\
\hline & $\begin{array}{l}\text { From natural ground level, south- } \\
\text { western part }\end{array}$ & Tibia & 1 & & 1 & & & \\
\hline & Robber pit, north-eastern part & Mandible & 1 & & & 1 & & \\
\hline \multirow{6}{*}{ Ovicaprine } & Chamber 1 (among human bones) & Sternum & 2 & & & 1 & & young individual \\
\hline & \multirow[t]{2}{*}{ Robber pit, central part } & Scapula & 2 & & & 1 & & \multirow[t]{5}{*}{$\begin{array}{l}\text { adult individual } \\
\text { or individuals }\end{array}$} \\
\hline & & Humerus & 4 & & & 1 & & \\
\hline & Robber pit, northern part & Tibia & 2 & & & 1 & & \\
\hline & $\begin{array}{l}\text { From natural ground level, south- } \\
\text { western part }\end{array}$ & Humerus & 1 & & & 1 & & \\
\hline & Superstructure, eastern part & Tibia & 1 & & & 1 & & \\
\hline
\end{tabular}

PRODUCED BY U. IWASZCZUK 
Group 1 in chamber 1 consisted exclusively of cattle remains ( 53 fragments from 4 bones) from the thorax and proximal part of a hind limb. Group 2 also consisted exclusively of cattle remains ( 25 fragments from 2 bones), which came from the thorax and proximal part of the forelimb. In the southern part, together with human remains, 1 cattle rib and 2 fragments of ovicaprine sternum were found.

Only cattle remains were also discovered in chamber 2. This was the most numerous assemblage from this grave (315 fragments from 30 bones) and it consisted of bones representing the thorax and proximal parts of the limbs.

Another 4 cattle bones were found in the central and south-eastern part of the shaft (a rib, femur, skull and tooth). The remains obtained from the robber pit and superstructure were very similar: in both cases there was 1 cattle bone and 2 or 3 ovicaprine bone fragments.

The only marks observed featured on cattle remains; no marks were observed on ovicaprine bones. A few bones had been chopped (sternum, rib, and tibia), filleted (rib) and in 2 cases it was possible to detect marks suggesting dismembering (a scapula bore a cut mark on the caudal angle, and another cut mark was also visible on the proximal end of a tibia). Additionally, a mild inflammatory process was noted on a cattle tibia near the line of fusion of the proximal end and of the shaft.

\subsubsection{Tumulus 23}

Only a few animal bones were discovered in chamber 2 . They were not, however, submitted for analysis.

\subsubsection{Tumulus 24}

Animal bones were discovered in two chambers: 1 and 4 . In chamber 1 they were found in the eastern part, mixed with human remains, and in the south-eastern part (see Chapter 3.3, Fig. 3.75). In chamber 4 they occupied the north-west corner of the chamber. Altogether, 1,171 bone fragments were recovered from this grave, 445 of which could not be identified. The majority of the bones came from cattle and ovicaprines; there were also 2 bird bones [Table 8.15]. Cattle remains came from 3 individuals: one was about 2-2.5 years old, the second was between $15^{-}$ 20 months and 3.5-4 years old, and the third one was an adult (it was represented by only 1 fragment of rib). Sheep remains belonged to 2 individuals: one younger, between $3^{-4}$ months and 3-3.5 years old, and one adult. Two adult goat bones were also found in this tumulus, which was unexpected in the context of the other graves. There were no goat bones in the studied material recovered from the chambers. Additionally, 2 bones (calcaneus and rib) belonged to an adult ovicaprine of undetermined species.
Some of the bones in chamber 1 were mixed with human remains; there were cattle and ovicaprine bones among them. It was possible to identify 9 ovicaprine bones (35 fragments) as belonging to sheep. Cattle, as well as ovicaprine remains, came from the thorax and proximal parts of limbs.

The majority of bone fragments were located in the south-eastern part of chamber 1 . In the case of cattle, bone fragments were numerous, though the number of bones represented in this assemblage was rather low: 271 fragments from 15 bones. There were not only bones from the thorax and proximal parts of limbs but also a skull fragment. Head elements have very rarely been found in the burial and side chambers of the El-Zuma tumuli. The only examples recorded to date were those in chamber 1 of $\mathrm{T} .3$ and chamber 1 of T.24. In both cases (a tooth from chamber 1 in T.3 and a fragment of skull from chamber 1 in T.24) only small fragments were found in the mixed bone material. It cannot be ruled out that they were put there intentionally; however, it is also probable that they got there accidentally. In both cases the chambers were looted and the materials mixed; therefore, the original content is not certain. In T.24 the ceiling of chamber 1 had collapsed, and the eastern part was covered with the fill of the superstructure (sand and gravel). Ovicaprine bones were also found in greater numbers in the south-eastern part of chamber 1, where 100 fragments from 19 bones were found. Two species were recognized in this material: sheep (only a pelvis could be identified) and goat ( 2 bones were determined: tibia and talus). The rest of the bones could not be identified to species. All ovicaprine bones came from the thorax and proximal parts of limbs. In this assemblage there were also 2 fragments of long bones that belonged to a bird. It was one of two examples of bird bones found in a burial chamber at El-Zuma. The second example of a bird bone was discovered in the burial chamber of T.21 (a type III tumulus). But these were not the only bird bones found inside the graves. They were also present among the bone material from the tunnels of type I tumuli (T.1, T.3, T.6, and T.8) with the mixed material, partially accidental. As the burial chambers of both T.21 and T.24 were looted and their ceilings collapsed, it seems probable that these bones were not part of the original content of the chambers.

An assemblage located originally in the north-western part of chamber 4 consisted of cattle and ovicaprine bones. There were 232 fragments from 14 cattle bones, among them bones from the thorax and proximal part of a hind limb. Only fragments of 1 rib belonged to an ovicaprine. The remains probably came from the same individuals as the remains in chamber 1 . 
TABLE 8.15 Animal remains discovered in T.24

\begin{tabular}{|c|c|c|c|c|c|c|c|c|}
\hline \multirow[t]{2}{*}{ Species } & \multirow[t]{2}{*}{ Context } & \multirow[t]{2}{*}{ Bone } & \multirow{2}{*}{$\begin{array}{l}\text { Number of } \\
\text { fragments }\end{array}$} & \multicolumn{3}{|c|}{ Number of bones } & \multirow[t]{2}{*}{ Marks left by termites } & \multirow[t]{2}{*}{ Description } \\
\hline & & & & Right & Left & Right/left & & \\
\hline \multirow{16}{*}{ Cattle } & \multirow{8}{*}{ Chamber 1, south-eastern part } & Skull & 1 & & & 1 & & \multirow{16}{*}{$\begin{array}{l}3 \text { individuals: } \\
1 \text { about } 2-2.5 \\
\text { years old, } 1 \\
\text { between } 15^{-} \\
20 \text { months } \\
\text { and } 3 \cdot 5^{-4} \\
\text { years old, } 1 \\
\text { adult ( } 1 \text { frag- } \\
\text { ment of rib } \\
\text { only) }\end{array}$} \\
\hline & & Lumbar vertebrae & 3 & & & 2 & & \\
\hline & & Sternum & 4 & & & 2 & & \\
\hline & & Rib & 205 & $\geq 2$ & $\geq 2$ & 1 & present on $3 \circ$ fragments & \\
\hline & & Scapula & 24 & 1 & & & & \\
\hline & & Humerus & 16 & 1 & & & & \\
\hline & & Pelvis & 10 & 1 & 1 & & & \\
\hline & & Femur & 8 & 1 & & & & \\
\hline & \multirow{5}{*}{ Chamber 1, north-eastern part } & Lumbar vertebrae & 2 & & & 1 & present & \\
\hline & & Rib & 23 & & & $2 ?$ & present on 9 fragments & \\
\hline & & Scapula & 17 & & & 1 & & \\
\hline & & Pelvis & 5 & 1 & & & present & \\
\hline & & Femur & 3 & 1 & & & & \\
\hline & & Rib & 192 & 4 & 4 & 2 & present on 8 fragments & \\
\hline & Chamber 4, north-western part & Tibia & 38 & 1 & 1 & & & \\
\hline & & Talus & 2 & 1 & 1 & & & \\
\hline \multirow{10}{*}{ Sheep } & \multirow{7}{*}{$\begin{array}{l}\text { Chamber } 1 \text { (among human } \\
\text { bones) }\end{array}$} & Rib & 15 & & & 1 & & \multirow{10}{*}{$\begin{array}{l}2 \text { individu- } \\
\text { als: } 1 \text { between } \\
3-4 \text { months } \\
\text { and } 3-3 \cdot 5 \\
\text { years old, } 1 \\
\text { adult (scap- } \\
\text { ula, humerus } \\
\text { and pelvis } \\
\text { only) }\end{array}$} \\
\hline & & Scapula & 1 & & 1 & & & \\
\hline & & Humerus & 1 & & 1 & & & \\
\hline & & Radius & 3 & & 1 & & & \\
\hline & & Ulna & 2 & & 1 & & & \\
\hline & & Pelvis & 5 & & 1 & & & \\
\hline & & Calcaneus & 1 & & 1 & & & \\
\hline & Chamber 1, south-eastern part & Pelvis & 8 & 1 (part) & 1 & & & \\
\hline & \multirow{2}{*}{ Chamber 1, north-eastern part } & Scapula & 6 & 1 & & & present & \\
\hline & & Humerus & 1 & 1 & & & & \\
\hline \multirow{2}{*}{ Goat } & \multirow{2}{*}{ Chamber 1, south-eastern part } & Tibia & 5 & 1 & & & & \multirow{2}{*}{1 adult animal } \\
\hline & & Talus & 1 & 1 & & & & \\
\hline \multirow{10}{*}{ Ovicaprine } & $\begin{array}{l}\text { Chamber } 1 \text { (among human } \\
\text { bones) }\end{array}$ & Rib & 4 & & & 1 & & \multirow{10}{*}{$\begin{array}{l}\text { from } 2 \text { of the } \\
\text { above sheep } \\
\text { (most of the } \\
\text { bones come } \\
\text { from the } \\
\text { young indi- } \\
\text { vidual, only } \\
\text { calcaneus } \\
\text { and rib come } \\
\text { from the adult } \\
\text { individual) }\end{array}$} \\
\hline & \multirow{6}{*}{ Chamber 1, south-eastern part } & Sternum & 1 & & & 1 & & \\
\hline & & Rib & 92 & 4 & 5 & 5 & present on 14 fragments & \\
\hline & & Humerus & 1 & 1 & & & & \\
\hline & & Pelvis & 4 & & 1 & & & \\
\hline & & Tibia & 1 & & & 1 & present & \\
\hline & & Calcaneus & 1 & & 1 & & & \\
\hline & \multirow{3}{*}{ Chamber 1, north-eastern part } & Rib & 7 & & & 2 & & \\
\hline & & Pelvis & 1 & 1 (part) & & & & \\
\hline & & Femur & 1 & & & 1 & & \\
\hline
\end{tabular}


TABLE 8.15 Animal remains discovered in T.24 (cont.)

\begin{tabular}{l|l|l|l|l|l|l|l|l}
\hline Species & Context & Bone & \multirow{2}{*}{$\begin{array}{l}\text { Number of } \\
\text { fragments }\end{array}$} & & \multicolumn{2}{|c|}{ Number of bones } & Marks left by termites & Description \\
\cline { 3 - 7 } & & & Right & Left & Right/left & \\
\hline Ovicaprine & Chamber 4, north-western part & Rib & 9 & & 1 & \\
\hline Bird & Chamber 1, south-eastern part & long bones & 2 & & 2 & 1 individual \\
\hline
\end{tabular}

PRODUCED BY U. IWASZCZUK

Some of the bones bore post-consumption marks. Filleting marks were observed on both cattle (most of the ribs, a lumbar vertebra, sternum, and femur) and ovicaprine bones (ribs and a few sheep bones: scapula, humerus, radius, and pelvis). Cattle bones were additionally chopped ( 2 ribs, a pelvis, and femur).

\subsubsection{Tumulus 26}

Animal remains, as a part of offering deposits, were mostly placed in the chambers of the tomb, but two bones were also found among the bricks of a blocking wall. 553 animal bones and bone fragments were discovered in the tumulus, but because of their poor state of preservation (the specimens were dry and fragile) 98 fragments remain unidentified. The material came from one cattle and two sheep [Table 8.16]. The cattle remains belonged to an animal about 3.5-4 years old. The sheep bones came from two individuals: one about $15^{-20}$ months old and an older one aged about 3.5 years. Chamber 1 contained four beef cuts: ribs, two left humeri, and one right pelvis. In chamber 2 there were remains of two species: cattle and sheep. The cattle bones were found on the floor in the southern part of the chamber and inside two bowls slipped and burnished on both sides (Z26/24 and $\left.\mathrm{Z}_{2} 6 / 75\right)$. Three parts of the cattle carcass lay on the floor: a fragment of thorax, a big part of the left forelimb, and bones from the proximal part of the right hind limb. Cattle ribs and lumbar vertebrae had been put into bowl $\mathrm{Z}_{2} 6 / 24$ together with a sheep rib, two cuts from the proximal part of the forelimb, and 2 fragments of the proximal part of the hind limbs. In bowl $\mathrm{Z}_{2} 6 / 75$ there were only cattle ribs. Chamber 3 contained, among other things, cattle ribs and thoracic vertebrae, and part of a forelimb as well as part of a sheep thorax and right pelvis. In chamber 4 there were fewer animal remains: only cattle ribs and a sternum, mixed with two sheep femurs, were deposited on the floor. Some cattle and sheep bones bore marks of skinning, dismembering [Figs. 8.10, 8.11], chopping, and filleting [see Fig. 8.9].

\subsection{Type III Tumuli}

The discovery context of the animal bones from some of the type III tumuli has already been outlined elsewhere
(Iwaszczuk 2015, 428-429; Iwaszczuk, Niderla-Bielińska, and Ścieżyńska 2019, 23-26).

\subsubsection{Tumulus 17}

Animal remains from this tumulus have already been discussed (Iwaszczuk, Niderla-Bielińska, and Ścieżyńska 2019, 23-26). It is interesting that this tomb was one of the two type III tumuli that contained not only ovicaprine but also cattle bones [Table 8.17]. In both cases only one cattle bone was found inside the chamber. Such a discovery is interesting in the light of other finds from these graves (see Chapter 3, in this volume). They were poorly equipped in comparison with graves such as T.21 and T.27, so the presence of cattle bone cannot be connected directly with the special status of the deceased. But the question about why these two bones were present in type III tumuli remains unresolved, unless we assume that the bones got into the chamber accidentally, which was possible but highly improbable given that cattle bones are big enough to not be accidentally moved along with sand.

\subsubsection{Tumulus 18}

No animal bones were recorded in this grave.

\subsubsection{Tumulus 19}

Only a few animal bones were found together with human remains in the burial chamber [Table 8.18]. A cattle rib came from an animal under 5 years old. There was also a sheep pelvis, as well as lumbar vertebrae, and the tibia of an ovicaprine. These bones probably belonged to a young individual under $15^{-2} \mathrm{O}$ months old. There were no marks on the bones.

\subsubsection{Tumulus 20}

The remains from this tumulus have been analysed before (Iwaszczuk, Niderla-Bielińska, and Ścieżyńska 2019, 2325). They were very typical of the type III tumuli, and contained only ovicaprine remains found in the shaft (mixed with human remains), and the burial chamber (only 1 fragment of pelvis). The bones came from the proximal parts of limbs, but there was also 1 fragment of mandible found among human remains [Table 8.19]. 


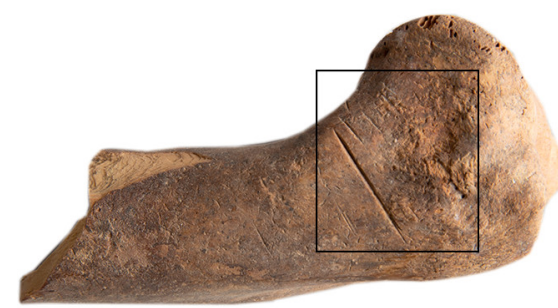

$1 \mathrm{~cm} \quad a:$ T.26, Chamber 2

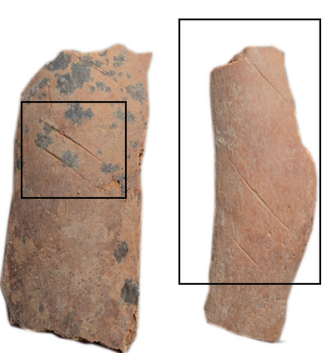

$1 \mathrm{~cm}$

b: T.26, Chamber 2

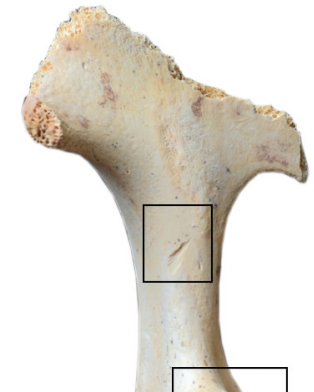

$1 \mathrm{~cm}$

$$
\underline{1 \mathrm{~cm}}
$$

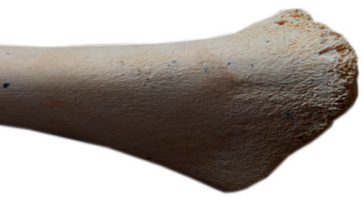

c: T.13, Chamber 3

FIGURE 8.11 Dismemberment and filleting marks visible on ovicaprine bones from El-Zuma: a-

dismemberment marks on a sheep humerus; $b$ - filleting marks on ovicaprine ribs; $c$ -

filleting marks on an ovicaprine tibia; $\mathrm{d}$-dismemberment mark and probable skinning

mark on a sheep pelvis

PнотоS BY A. KAMROWSKI

TABLE 8.16 Animal remains discovered in T.26

\begin{tabular}{|c|c|c|c|c|c|c|c|c|}
\hline \multirow[t]{2}{*}{ Species } & \multirow[t]{2}{*}{ Context } & \multirow[t]{2}{*}{ Bone } & \multirow{2}{*}{$\begin{array}{l}\text { Number of } \\
\text { fragments }\end{array}$} & \multicolumn{3}{|c|}{ Number of bones } & \multirow{2}{*}{$\begin{array}{l}\text { Marks left by } \\
\text { termites }\end{array}$} & \multirow[t]{2}{*}{ Description } \\
\hline & & & & Right & Left & Right/left & & \\
\hline \multirow{18}{*}{ Cattle } & \multirow{3}{*}{ Chamber 1} & Rib & 6 & & 1 & 2 & & \multirow{18}{*}{$\begin{array}{l}1 \text { individual: about } \\
3 \cdot 5^{-4} \text { years old }\end{array}$} \\
\hline & & Humerus & 4 & & 1 & & & \\
\hline & & Pelvis & 6 & 1 & & & & \\
\hline & \multirow{8}{*}{ Chamber 2} & Lumbar vertebrae & 5 & & & 2 & & \\
\hline & & Sternum & 23 & & & 5 & & \\
\hline & & Rib & 41 & 1 & 1 & 3 & & \\
\hline & & Pelvis & 12 & & 1 & & & \\
\hline & & Femur & 30 & 1 & 1 & & & \\
\hline & & Patella & 2 & 1 & 1 & & & \\
\hline & & Tibia & 15 & 1 & 1 & & & \\
\hline & & Talus & 1 & & 1 & & & \\
\hline & \multirow{2}{*}{ Chamber 2, in vessel $Z_{2} 6 / 24$} & Lumbar vertebrae & 5 & & & 1 & & \\
\hline & & Rib & 12 & & & 2 & & \\
\hline & Chamber 2, in vessel Z26/75 & Rib & 2 & & & 2 & present on 1 fragment & \\
\hline & \multirow{4}{*}{ Chamber 3} & Thoracic vertebrae & 14 & & & 4 & & \\
\hline & & Rib & 32 & & 1 & 3 & & \\
\hline & & Radius & 3 & & 1 & & & \\
\hline & & Ossa carpi & 5 & & & 5 & & \\
\hline
\end{tabular}


TABLE 8.16 Animal remains discovered in T.26 (cont.)

\begin{tabular}{|c|c|c|c|c|c|c|c|c|}
\hline \multirow[t]{2}{*}{ Species } & \multirow[t]{2}{*}{ Context } & \multirow[t]{2}{*}{ Bone } & \multirow{2}{*}{$\begin{array}{l}\text { Number of } \\
\text { fragments }\end{array}$} & \multicolumn{3}{|c|}{ Number of bones } & \multirow{2}{*}{$\begin{array}{l}\text { Marks left by } \\
\text { termites }\end{array}$} & \multirow[t]{2}{*}{ Description } \\
\hline & & & & Right & Left & Right/left & & \\
\hline \multirow{4}{*}{ Cattle } & \multirow{2}{*}{ Chamber 4} & Sternum & 7 & & & 2 & & \\
\hline & & Rib & 25 & & & 3 & & \\
\hline & \multirow{2}{*}{ Shaft, blocking wall } & Rib & 1 & & & 1 & & \multirow{2}{*}{$\begin{array}{l}\text { adult individual or } \\
\text { individuals }\end{array}$} \\
\hline & & Humerus & 1 & & & 1 & & \\
\hline \multirow{11}{*}{ Sheep } & Chamber 1 & Tibia & 4 & & 1 & & & \multirow{11}{*}{$\begin{array}{l}2 \text { individuals: } \\
1 \text { about } 15-20 \\
\text { months old, } 1 \\
\text { about } 3.5 \text { years } \\
\text { old }\end{array}$} \\
\hline & \multirow{6}{*}{ Chamber 2} & Scapula & 8 & 1 & 1 & & & \\
\hline & & Humerus & 9 & 1 & 1 & & & \\
\hline & & Radius & 4 & 1 & 1 & & & \\
\hline & & Ulna & 2 & & 1 & & & \\
\hline & & Femur & 12 & 1 & 1 & & $\begin{array}{l}\text { present on } 5 \text { frag- } \\
\text { ments }\end{array}$ & \\
\hline & & Tibia & 2 & & 1 & & & \\
\hline & \multirow{2}{*}{ Chamber 2, in vessel Z26/24 } & Calcaneus & 1 & 1 & & & & \\
\hline & & Talus & 1 & 1 & & & & \\
\hline & Chamber 3 & Pelvis & 4 & 1 & & & & \\
\hline & Chamber 4 & Femur & 11 & 1 & 1 & & & \\
\hline \multirow{19}{*}{ Ovicaprine } & \multirow{9}{*}{ Chamber 2} & Rib & 70 & 2 & 1 & 3 & & \multirow{19}{*}{$\begin{array}{l}\text { probably from } 2 \text { of } \\
\text { the above sheep }\end{array}$} \\
\hline & & Lumbar vertebrae & 2 & & & 2 & & \\
\hline & & Humerus & 3 & & 1 & & & \\
\hline & & Ulna & 1 & & & 1 & & \\
\hline & & Pelvis & 5 & 1 & 1 & & & \\
\hline & & Femur & 10 & 1 & 1 & & & \\
\hline & & Patella & 1 & & 1 & & & \\
\hline & & Tibia & 10 & 1 & 1 & & & \\
\hline & & Calcaneus & 1 & & 1 & & & \\
\hline & \multirow{6}{*}{ Chamber 2, in vessel Z26/24 } & Rib & 10 & & & 1 & & \\
\hline & & Scapula & 6 & & & 1 & & \\
\hline & & Ulna & 1 & 1 & & 1 & & \\
\hline & & Femur & 5 & & 1 & & & \\
\hline & & Patella & 1 & & 1 & & & \\
\hline & & Centroquartale & 1 & & & 1 & & \\
\hline & \multirow{4}{*}{ Chamber 3} & Lumbar vertebrae & 7 & & & 2 & & \\
\hline & & Caudal vertebrae & 1 & & & 1 & & \\
\hline & & Sacrum & 4 & & & 1 & & \\
\hline & & Rib & 7 & & & 1 & present & \\
\hline
\end{tabular}

PRODUCED BY U. IWASZCZUK 
TABLE 8.17 Animal remains discovered in T.17

\begin{tabular}{|c|c|c|c|c|c|c|c|c|}
\hline \multirow[t]{2}{*}{ Species } & \multirow[t]{2}{*}{ Context } & \multirow[t]{2}{*}{ Bone } & \multirow{2}{*}{$\begin{array}{l}\text { Number of } \\
\text { fragments }\end{array}$} & \multicolumn{3}{|c|}{ Number of bones } & \multirow{2}{*}{$\begin{array}{l}\text { Marks left by } \\
\text { termites }\end{array}$} & \multirow[t]{2}{*}{ Description } \\
\hline & & & & Right & Left & Right/left & & \\
\hline Cattle & Chamber & Ulna & 3 & & & 1 & & 1 individual \\
\hline \multirow{7}{*}{ Sheep } & \multirow{7}{*}{ Chamber } & Sternum & 2 & & & 2 & & \multirow{7}{*}{1 individual: between 3 and 3.5 years old } \\
\hline & & Femur & 4 & 1 & & & & \\
\hline & & Tibia & 1 & 1 & & & present & \\
\hline & & Talus & 1 & 1 & & & & \\
\hline & & Calcaneus & 1 & 1 & & & & \\
\hline & & Centroquartale & 1 & & & 1 & & \\
\hline & & Sesamoid & 1 & 1 & & & & \\
\hline Ovicaprine & Chamber & Rib & 1 & & & 1 & & probably from the above sheep \\
\hline
\end{tabular}

PRODUCED BY U. IWASZCZUK

TABLE 8.18 Animal remains discovered in T.19

\begin{tabular}{|c|c|c|c|c|c|c|c|c|}
\hline \multirow[t]{2}{*}{ Species } & \multirow[t]{2}{*}{ Context } & \multirow[t]{2}{*}{ Bone } & \multirow{2}{*}{$\begin{array}{l}\text { Number of } \\
\text { fragments }\end{array}$} & \multicolumn{3}{|c|}{ Number of bones } & \multirow{2}{*}{$\begin{array}{l}\text { Marks left by } \\
\text { termites }\end{array}$} & \multirow[t]{2}{*}{ Description } \\
\hline & & & & Right & Left & Right/left & & \\
\hline Cattle & Chamber & Rib & 2 & & & 1 & & young individual under 5 years old \\
\hline Sheep & Chamber & Pelvis & 3 & & & 1 & & \multirow{3}{*}{$\begin{array}{l}\text { probably } 1 \text { young individual under } 15^{-20} \\
\text { months old }\end{array}$} \\
\hline \multirow{2}{*}{ Ovicaprine } & \multirow{2}{*}{ Chamber } & Lumbar vertebrae & 1 & & & 1 & & \\
\hline & & Tibia & 2 & & 1 & & & \\
\hline
\end{tabular}

PRODUCED BY U. IWASZCZUK

TABLE 8.19 Animal remains discovered in T.2O

\begin{tabular}{|c|c|c|c|c|c|c|c|c|}
\hline \multirow[t]{2}{*}{ Species } & \multirow[t]{2}{*}{ Context } & \multirow[t]{2}{*}{ Bone } & \multirow{2}{*}{$\begin{array}{l}\text { Number of } \\
\text { fragments }\end{array}$} & \multicolumn{3}{|c|}{ Number of bones } & \multirow{2}{*}{$\begin{array}{l}\text { Marks left by } \\
\text { termites }\end{array}$} & \multirow[t]{2}{*}{ Description } \\
\hline & & & & Right & Left & Right/left & & \\
\hline \multirow{2}{*}{ Sheep } & \multirow{2}{*}{ Shaft (among human bones) } & Humerus & 1 & & & 1 & & \multirow{2}{*}{$\begin{array}{l}1 \text { individual: under } 3-3.5 \text { years } \\
\text { old }\end{array}$} \\
\hline & & Talus & 1 & & & 1 & & \\
\hline \multirow{5}{*}{ Ovicaprine } & Chamber & Pelvis & 2 & & 1 & & & \multirow{5}{*}{ probably from the above sheep } \\
\hline & \multirow{4}{*}{ Shaft (among human bones) } & Mandible & 4 & & & 1 & & \\
\hline & & Scapula & 2 & & & 1 & & \\
\hline & & Ulna & 1 & & & 1 & & \\
\hline & & Pelvis & 2 & 1 & & & & \\
\hline
\end{tabular}

PRODUCED BY U. IWASZCZUK 
TABLE 8.20 Animal remains discovered in T.21

\begin{tabular}{|c|c|c|c|c|c|c|c|c|}
\hline \multirow[t]{2}{*}{ Species } & \multirow[t]{2}{*}{ Context } & \multirow[t]{2}{*}{ Bone } & \multirow{2}{*}{$\begin{array}{l}\text { Number of } \\
\text { fragments }\end{array}$} & \multicolumn{3}{|c|}{ Number of bones } & \multirow{2}{*}{$\begin{array}{l}\text { Marks left by } \\
\text { termites }\end{array}$} & \multirow[t]{2}{*}{ Description } \\
\hline & & & & Right & Left & Right/left & & \\
\hline \multirow{7}{*}{ Sheep } & \multirow{7}{*}{ Chamber } & Scapula & 4 & & 1 & & & \multirow{7}{*}{1 individual: about $3-4$ months old } \\
\hline & & Humerus & 4 & & 1 & & & \\
\hline & & Radius & 5 & & 1 & & & \\
\hline & & Tibia & 3 & & & 1 & & \\
\hline & & Calcaneus & 1 & & & 1 & & \\
\hline & & Talus & 1 & & & 1 & & \\
\hline & & Metatarsus & 2 & & & 1 & & \\
\hline \multirow{7}{*}{ Ovicaprine } & \multirow{7}{*}{ Chamber } & Sternum & 7 & & & 1 & & \multirow{7}{*}{ probably from the above individual } \\
\hline & & Rib & 30 & & & 7 & & \\
\hline & & Humerus & 3 & 1 & & & & \\
\hline & & Ulna & 2 & & 1 & & & \\
\hline & & Ossa carpi & 1 & & & 1 & & \\
\hline & & Pelvis & 4 & & & 1 & & \\
\hline & & Tibia & 4 & & & 1 & & \\
\hline Carnivore & Shaft & Ph I & 2 & & & & & adult \\
\hline Bird & Chamber & Long bone & 1 & & & 1 & & \\
\hline
\end{tabular}

PRODUCED BY U. IWASZCZUK

\subsubsection{Tumulus 21}

The animal remains have been described before (Iwaszczuk 2015). Sheep and a bird were the only species represented in this tumulus [Table 8.20]. The sheep bones came from the more valued parts of the carcass of an animal aged about 4 months.

\subsubsection{Tumulus 22}

Only bones from the re-excavation of the grave were submitted for analysis. The material, however, was mixed and the remains had no specified context, so they were not ultimately included in the analysis.

\subsubsection{Tumulus 27}

No animal bones were recorded in this tumulus.

\subsubsection{Tumulus 28}

Only 1 fragment of ovicaprine pelvis was found during the excavation of this tumulus. The fragment was, however, discovered in the superstructure of the grave, so it is probable that it was unconnected with any funerary rituals.

\section{Discussion: Funerary Rituals on the Basis of Animal Remains}

It seems that most of the animal remains found in El-Zuma were deposited in the graves during the funerary ritual or rituals. The rituals, however, were different in the case of the different types of tumuli. The most complicated rituals were performed for those buried in type I tumuli, the simplest ones for those interred in type II t tumuli, which might have been connected with the social status of the people buried in the different types of tumuli. The most popular animal offerings, found in all types of tumuli, were food offerings, but there were also other types of rituals that left a material footprint in the form of animal remains. These will be analysed separately.

\subsection{Food Offerings}

The animal remains found in the grave chambers of all tumulus types represented bigger parts of cattle and sheep carcasses. These parts of the animal carcasses, probably prepared as meat cuts, were deposited in the tumuli as grave goods to serve the dead in the afterlife. Originally they were placed in the burial chamber as well as in the side chambers (not necessarily in all of them), but tomb robberies caused, among other things, their partial dis- 
placement into the grave shafts, and in the case of type I tumuli probably also into the tunnels. Not all graves were, however, equipped with food offerings. Three tumuli of type III (T.18, T.27 and T.28) did not contain any animal remains either in their chambers or shafts.

There were notable differences between the contents of tumuli of different types. It seems characteristic of the biggest and most richly equipped tumuli (types I and II) that remains came from both cattle and sheep, sometimes even two individuals of each species were placed inside the grave (T.11, T.12, T.14, T.16). In T.13, T.15, and T.24 as many as 3 cattle carcasses were represented. The smallest tumuli (type III) contained only sheep bones, and in all cases only the remains of 1 animal were recorded. Only 2 exceptions from this rule are known: in each of two tumuli (T.17 and T.19), a single cattle bone was found together with ovicaprine remains.

It seems obvious on the basis of the recorded bones that only certain parts of the carcasses were used as offerings. In most cases, even if the bone material was mixed, the pattern of depositing whole parts of cattle and sheep carcasses (joints) was confirmed. In the excavated chambers of tumuli of types I and II both species, cattle and sheep, were represented by articulated and disarticulated thorax elements as well as forelimbs and hind limbs without extremities. Meat cuts came from top quality parts of the carcasses, with large amounts of meat. Cattle slaughtered for such offerings were usually young (under $3.5^{-4}$ years old) or relatively young (about $3 \cdot 5^{-4}$ years old). Sheep were young (under 3.5 years old) or adult. No bones belonging to old individuals were found in ritual contexts, which confirms the careful choice of meat intended as food offerings. Such a pattern has also been noted at other cemeteries from the region, such as El-Sadda 1 (Osypińska 2007), Tanqasi (Osypińska 2008), El-Kassinger Bahry (Makowiecki 2007) and El-Detti (Iwaszczuk 2016). The young age of offertory animals was reported from all these sites. In the case of tumulus $\mathrm{HP} 45 / 1$ at El-Kassinger Bahry Makowiecki estimated the age of the slaughtered sheep at 12-15 months and 12-18 months old. Osypińska also confirmed the presence of relatively young ovicaprine bones, from individuals aged about 3.5 years, in graves 67 and 83 at El-Sadda. In tumulus 87 at Tanqasi the analysed ovicaprines were between 5 months and 3 years old; however, the cattle remains came from an animal over 4 years old. Almost exclusively young sheep and barely adult cattle remains were also discovered in El-Detti. No old animals were reported from any of these sites.

The presence of post-consumption marks, as well as marks suggesting skinning and dividing the carcasses into small pieces, also indicates that the deposited bones were intended as food offerings. Such marks were also present on the bones from El-Kassinger Bahry (Makowiecki 2007) and El-Detti (Iwaszczuk 2016), but it is interesting that they were not reported from the Tanqasi and El-Sadda 1 cemeteries. It seems obvious that the animals were carefully chosen for these offerings. There were no preferences as to the side of the body from which the meat cuts were offered for the deceased. Carcasses were divided into smaller pieces, but in some cases bigger parts of carcasses, such as forelimb or hind limb without extremities, were placed among the other grave goods. In some cases a beef or mutton dish was also served: the presence of ribs and sometimes also other bones inside bowls, noted in type II tumuli, should be considered in such a context. There were 2 cases when bigger meat cuts were placed inside vessels: in chamber 3 of T.12 a number of cattle bones were registered in vessel $Z_{12} / 125$, and in chamber 2 of T.26 some sheep remains were found inside the small bowl $\mathrm{Z}_{2} 6 / 24$. In some instances (vessels Z13/11 from chamber 5 and Z13/27 from chamber 3 of T.13, vessel Z15/35 from chamber 2 of T.15, and vessels $Z_{2} 6 / 24$ and $Z_{2} 6 / 75$ from chamber 2 of T.26), the bones found inside the bowls may suggest that a liquid could have originally accompanied the bonesall these bowls were slipped and burnished on both sides, which helps to keep liquid inside the vessel. In other cases, bigger meat cuts were placed on the bowls and not inside them (e.g. fragments of cattle pelvis were found inside cup Z11/19 from chamber 2 in T.11 and around it)-perhaps they were also prepared in some way. In the case of the bowl $\left(\mathrm{Z}_{12} / 125\right)$ containing cattle bone fragments, the vessel was large and shallow, slipped only inside-a meatdish could have been prepared and served in it for the dead.

The animals were probably slaughtered outside the cemetery and certainly outside the graves. No place which could have been used for butchering the animals and dividing the carcasses was found at the El-Zuma site either during the survey or during the excavations. This suggests two scenarios: the existence of such a place elsewhere, or the slaughtering of animals in the village inhabited by the society that buried its dead in the tumuli at El-Zuma. Both scenarios are equally probable in the light of available evidence.

\subsection{Other Forms of Ritual}

It seems probable that other forms of rituals besides food offerings also accompanied the funerals at El-Zuma in the Early Makurian period. The animal remains found in contexts other than chambers (and partially shafts) differ from the assemblages connected with food offerings. It is possible to discuss three types of such rituals on the basis 
of animal remains: animal offerings accompanying funerary rituals, feasting during funerary rituals, and probable banquets after funerary rituals.

\subsubsection{Animal Offerings Accompanying Funerary Rituals}

Unusual animal bone fragments were found in the tunnels of type I tumuli. The zoological variety of the remains observed in the tunnels of T.1 and T.4 suggests the existence of different types of funerary rituals. At least one of these graves (T.4) was exceedingly well equipped (see Chapter 3.2, this volume). The presence in these structures of large fragments of skeletons of transport animals, such as camel and donkey, as well as gazelle bones, is reminiscent of the situation known from the tumuli at the cemetery in Qustul (Emery and Kirwan 1938, 27-74, Pls. 9, 11-14). Whole animal skeletons (cattle and ovicaprine as well as transport animals and dogs) were discovered there lying on the ramps and in the corridors of the very richly equipped graves (including Qustul tombs 17, 25 and 31). A similar situation was observed in Firka: for example, in tomb 11 at least one camel was buried lying on its side with its head directed down to the main chamber. The skull of this animal bore chopping marks (Kirwan 1935, 192, 193, Fig. 5). Altogether, skeletons of cattle, sheep, horse, and camel were discovered in three tumuli (nos. 11, 12, and 14), the biggest ones at the Firka cemetery. Transport animals, sometimes with decorative elements, such as bronze bells or necklaces of faience beads and cowrie shells, were found on the ramp, while cattle and sheep remains were usually located in the pit by the main chamber (Kirwan 1935, 192-194). Though the remains found in T.1 and T.4 in El-Zuma were broken into pieces, scattered along the tunnels and mixed with human bones and other finds, they represented different parts of the skeleton, not only the thorax and proximal parts of limbs as it was in the case of the remains found in the chambers of tumuli from this cemetery. Both tumuli were looted and robbers got to the graves through the shaft leading into the tunnel, so the graves were open for some time, which was attested by bat remains found in different levels of the fill of T.4, as well as by bird bones found in the tunnel of T.1, and some accidental finds, such as a single carnivore rib and two vertebrae in T.4. The other type I tumuli were also looted in this way and some remains, like the bird and micro-mammal bones from T.3, T.6, and T.8 or the single porcupine mandible found in T.3, suggest that the graves could have been accessed in this way at least some time after the looting. It seems, however, improbable that almost-whole skeletons of big mammals could get into the tunnels accidentally along with sand sliding down into the open tunnels. It is therefore possible that similar rituals to those observed in Qustul and Firka may have been performed in the case of two tumuli at El-Zuma.

\subsubsection{Feasting during Funerary Rituals}

The question is, what happened to the carcass parts that remained after the offerings had been left inside the graves, as large fragments of them were not found among the food offerings. Probably they served as food during a feast that accompanied the funerary rituals, though no evidence to support this theory is provided by the animal remains from El-Zuma. It is possible that feasting also took place in the graves, or that people tried the dishes intended for the dead, because filleting marks were observed on the bones (usually on ribs, but not exclusively). Filleting marks are made when taking meat off the bone, which usually takes place when the meat is eaten (especially filleting marks observed on the ribs), and therefore they are commonly connected with the consumption and not with the preparation of meat.

\subsubsection{Probable Banquet after Funerary Rituals}

The remains of two sheep were found in the southern and south-eastern part of the shaft of T.12, on a level above the floor of the grave, in a separate cluster, together with a number of artefacts (mostly pottery) neatly placed (see Chapter 3.3, Fig. 3.45, this volume). Perhaps this kind of find was connected with a banquet that took place sometime after the funeral (as a layer of sand had already been formed by then) but before sealing the grave with the superstructure. Maybe also some other animal bone fragments discovered in the shafts of type II tumuli were the visible remains of such practices. There is also the possibility that this material was a component of the grave goods added there as a part of a separate ritual performed before the construction of the superstructure of the grave but, nevertheless, some time after the funeral and unconnected with a banquet.

\subsection{Time of Death and Chronology of Funerary Rituals}

As has been discussed before, it is probable that marks left by termites were recorded on the bones recovered from some graves at El-Zuma. If so, the implications for studies into ritual practices at El-Zuma are really interesting. The activity pattern of the colonies of some of the species of these small insects is especially noteworthy. According to Geerts, van der Linden, and van der Linden (2016) the maximum foraging activity of Baucaliotermes hainesi, the species of termite analysed by them, occurs only above $2 \mathrm{O}^{\circ} \mathrm{C}$. Backwell et al. $(2012,84)$ observed that Trinervitermes trinervoides do not forage during the June-August 
period and during the hottest months. These authors are convinced, therefore, that the destruction of bones is seasonal and connected with the lifecycle of the termites. Furthermore, the research carried out by Backwell and her team $(2012,79,84)$ showed clearly that termites consume bones not only for their protein and marrow lipid content but also because of various trace elements (calcium, phosphorous, and nitrogen), preferring fresh bones and bones with meat on them to fossilized ones. This was also confirmed by Thorne and Kimsey (1983) in their research. These two factors (seasonality and consumption of meat and fresh bones) are of great importance in the case of ElZuma. On the one hand, the seasonality of termite activity indicates that burials took place during different seasons. The tumuli in which the bones gnawed by termites were recorded were probably visited by them in search of forage in those seasons with moderate temperatures, while the burials in the tumuli without such bones would have taken place during the coldest or the hottest seasons. It confirms that the cemetery was used by people during normal life-death cycles and was not connected with sudden deaths caused by diseases or war. On the other hand, the search for meat and bone protein and lipids, as well as minerals, must have attracted termites to remains that were relatively fresh. It seems that though termites can build long tunnels underground, they must be tempted to do so, therefore forage must have been available at least close to the surface. It is possible then that the graves were sealed with blocking deposits (tumuli of type I and II), as the animal offerings in the side chambers were mostly intact, but not necessarily covered with sand and gravel structures, at least for some time after the burial. There is also a possibility that the burial chambers were not equipped at the same time as the body was placed in the main chamber but sometime later, in one or more separate rituals, and the graves were covered with superstructures after these rituals had been completed. Type II I tumuli contained virtually no bones gnawed by termites; the only fragment bearing such marks was discovered in T.17. It seems then that these graves were covered with superstructures almost immediately after the burial had taken place. It is interesting that the graves containing bones with termite gnawing marks were located in the central part of the cemetery, forming a strip of land indicating the existence of a path used by termites. But in this zone there were also graves without signs of termite activity, which confirms the theory of seasonality.

Rodent and bat remains were found in the tunnels of type I tumuli. It is possible, as discussed earlier, that gnawing marks were made by rodents (most probably not rats) while wearing down their incisors. If so, the bones must have already been meat-free, and the rodent activity would have taken place sometime after the burial, maybe after the graves had been looted, when the tunnels were left open. The theory that the tunnels remained open for a longer time is supported by the presence of bat skeletons, exclusively of 1 species, in the tunnel of T.4. This suggests the existence of a colony of these animals in the shelter provided by the tunnel, which would have been accessible from the outside at that time. Additionally, bat excrement covered the floor along the walls of chamber 1 of T.6 (see Chapter 3.2, Fig. 3.35, this volume) and chamber 1 of T.7 (see Chapter 3.2, Fig. 3.41, this volume) suggesting its prolonged usage.

\section{Summary}

The animal remains discovered in the various tumulus structures at El-Zuma were connected with different types of rituals. Bones found in chambers, and partially in shafts (especially fragments mixed with human remains and other finds), were most probably deposited in the graves as food offerings. The number of animals slaughtered for this purpose differed depending on the tumulus type. The smallest tumuli (type III) were equipped with meat of only one young sheep or contained no meat offerings. Probably $1-3$ young cattle and sheep were killed for meat that was used during the funerary rituals performed in type II tumuli. Additional rituals took place in the case of some type I tumuli. A large number of animals was slaughtered not only as food offerings but probably also as whole animal offerings (among them game and transport animals), which were deposited in the tunnels that most probably led to the burial chambers, maybe as animals to accompany the dead in the afterlife. The variety of rituals performed at El-Zuma sets this cemetery apart from other cemeteries in the region. It shows the wealth of some people buried there, as well as the social stratification of the society living in that neighbourhood during the Early Makurian period.

\section{Acknowledgements}

This research was conducted as part of the Opportunities for the El-Zuma/El-Dettiand Tanqasimicroregions economy research on the basis of animal bone remains from the funerary context, which received funding from the National Science Centre, Poland, under the PRELUdium grant agreement no. 2014/13/N/Hs3/0462O. 